JOGED

JURNAL SENI TARI 



\section{JOGED \\ JURNAL SENI TARI}

Jurnal Joged merangkai beberapa topik kesenian yang terkait dengan fenomena, gagasan konsepsi perancangan karya seni maupun kajian. Joged merupakan media komunikasi, informasi, dan sosialisasi antar insan seni perguruan tinggi ke masyarakat luas.

Redaktur menerima sumbangan tulisan yang belum pernah diterbitkan dalam media lain, format penulisan berada di halaman belakang. Naskah yang masuk akan disunting format, istilah dan tata cara lainnya.

\section{Pemimpin Umum:}

Ketua Jurusan Tari (ex-officio)

Pemimpin Redaksi:

Dr. Sumaryono, MA.

Wakil Pemimpin Redaksi:

Dr. Hendro Martono, M.Sn.

\section{Sekretaris Redaksi:}

Dra. Supriyanti, M. Hum.

\section{Staf Redaksi:}

1. Drs. Raja Alfirafindra, M.Hum.

2. Bekti Budi Hastuti, SST., M. Sn.

\section{Anggota Redaksi:}

1. Prof. Dr. Y. Sumandiyo Hadi. SST. SU.

2. Dr. Hersapandi, SST., M.S.

3. Dr. Rina Martiara, M. Hum.

4. Dra. M. Heni Winahyuningsih, M. Hum.

5. Dra. Daruni, M.Hum.

6. Dra. Budi Astuti, M.Hum.

7. Dra. Siti Sularini

\section{Desain Sampul:}

Dr. Hendro Martono, M.Sn.

\section{Alamat Redaksi dan Penerbit:}

Jurusan Tari Fak. Seni Pertunjukan ISI Yogyakarta, Jl. Parangtritis km 6,5 Yogyakarta 55188

Telp. 08121561257

Naskah dapat dikirim melalui salah satu alamat email di bawah ini:

Email: hersapandi@yahoo.com,priyantitari@yahoo.com,mar_yono@yahoo.co.id

\section{Dicetak oleh:}

Multi Grafindo, Ruko Perumahan Candi Gebang Permai I/4 Sleman Yogyakarta 55584,

Telp. (0274) 7499863, Fax.( 0274)888027

Email: admin@multigrafindo.com

Apabila mengutip atau menyalin naskah yang terdapat dalam jurnal ini, maka harus ada ijin dari penulis langsung atau mencantumkan dalam referensi sesuai dengan tata tulis akademis yang berlaku.

Iklan yang berhubungan dengan pengetahuan dan penciptaan seni dapat dimuat di jurnal ini. 



\section{JOGED \\ JURNAL SENI TARI}

Judul Tulisan

Tari Klana Alus Sri Suwela Gaya Yogyakarta Perspektif Joged Mataram

Pelajaran Tari : Image dan Kontribusinya Terhadap Pembentukan Karakter Anak

Sistem Pewarisan Penari Rol dalam Wayang Orang Panggung

Reog Obyogan Sebagai Profesi

Tari Gandrung Terob Sebagai Identitas Kultural Masyarakat Using Banyuwangi

Sistem Transmisi Wayang Wong Gaya Yogyakarta : Studi Kasus Karakteristik Pocapan

Wayang Wong Langen Lestari Budoyo Donomulyo Sebuah Kajian Gaya Wayang Wong Pedesaan

Peran Majlis Pusat Pertubuhan-Pertubuhan Budaya Melayu Singapura dalam Festival Tari Serumpun

\section{Nama Penulis}

Supriyanto

Kuswarsantyo

Dr. Hersapandi,Sst., Ms.

Hendro Martono

Rina Martiara dan Arie Yulia Wijaya

Sarjiwo

Surojo

Raja Alfirafindra
$57-69$

$70-77$

Halaman

1-16

$17-23$

24-35

$36-48$

$49-56$

78-86 



\section{PETUNJUK UMUM BAGI PENULIS}

1. Terbit $2 \mathrm{x}$ setahun (Mei dan November)

2. Penulis artikel: satu, dua atau tiga penulis (maksimal).

3. Mahasiswa dikenakan beaya terbit Rp. 150.000,00 (sekali terbit)

4. Bagi penulis umum beaya penerbitan Rp. $300.000,00$ dan bagi pelanggan $\mathrm{Rp}$. $200.000,00$

5. Semua penulis mendapat bukti penerbitan 4 eksemplar

6. Harga satuan Jurnal Rp. 30.000,00 pereksemplar

7. Beaya langganan untuk satu tahun dengan $2 \mathrm{x}$ penerbitan Rp. 50.000,00.

8. Artikel yang dimuat merupakan hasil penelitian/pemikiran atau perancangan seni.

9. Artikel bersifat ilmiah dengan dukungan sumber-sumber pustaka, dan diskografi bila diperlukan. Kutipan dengan sistem catatan perut. Catatan kaki bisa ditambahkan bilamana perlu.

10. Artikel terdiri $15 \mathrm{~s} / \mathrm{d} 20$ halaman kwarto, satu setengah spasi, huruf Times New Roman font 12 dengan lampiran biodata penulis.

11. Menyerahkan soft dan hard copy, abstrak bahasa Indonesia dan Inggris.

12. Artikel belum pernah dimuat di media cetak apapun.

13. Sistematika penulisan artikel ilmiah: Pendahuluan yang di dalamnya mencakup uraian Latar Belakang Masalah, Permasalahan, Kerangka Pemikiran/Landasan Teori, Metode Penelitian, Tujuan Penelitian yang ditulis bukan sebagai sub judul tersendiri; Isi berupa Pembahasan yang bersifat analitis-kritis dan telaah; Penutup yang mengemukakan jawaban atas permasalahan yang dijadikan fokus kajian; Catatan Akhir; dan terakhir Daftar Pustaka.
14. Kutipan lebih dari empat baris diketik dengan spasi tunggal dan diberi baris baru. Kutipan kurang dari empat baris dituliskan sebagai sambungan kalimat dan dimasukkan dalam teks memakai tanda petik.

15. Daftar Pustaka diurut secara alfabetis dengan nama belakang lebih dulu baik untuk nama penulis Indonesia maupun dari luar negeri. Daftar Pustaka hanya memuat literatur yang dirujuk di dalam naskah saja. Penulisan referensi sebagai contoh berikut: nama belakang penulis, tahun terbit, diikuti dengan judul buku dicetak miring dan judul artikel ditulis di dalam tanda petik diikuti dengan judul jurnal atau majalah atau judul buku bunga rampai yang dicetak miring, baru nama kota penerbit, dan terakhir nama penerbitnya. Lihat contoh di bawah ini:

Book, Peter. 2003. Percikan Pemikiran tentang Teater, Film, dan Opera. Terjemahan: Max Arif n. Jakarta: MSPI.

K.M., Saini. 2002. Kaleidoskop Teater Indonesia. Bandung: STSI Press.

Leahy, Louis. 2005. "Sains dan Pencarian Makna". Diskursus Jurnal Filsafat dan Teologi. Vol. 4 No. 1, April.

Wartika, Enok. 2004. Proses Tradisi Lisan dalam Melestarikan Legenda dan Mitos Situ Lengkong Panjalu Ciamis. Tesis Program Studi Ilmu Sosial Bidang Kajian Komunikasi. Bandung: Pascasarjana Universitas Padjadjaran. 



\title{
TARI KLANA ALUS SRI SUWELA GAYA YOGYAKARTA PERSPEKTIF JOGED MATARAM
}

\author{
Oleh: Supriyanto \\ Dosen Jurusan Tari Fakultas Seni Pertunjukan ISI Surakarta
}

\begin{abstract}
ABSTRAK
Tari Klana Alus Sri Suwela gaya Yogyakarta yang dikenal sampai sekarang ini merupakan tipe tari putra dengan karakter halus, dan hal ini dapat dilihat dari volume gerak serta visualisasi karakternya. Tari Klana Alus Sri Suwela gaya Yogyakarta merupakan salah satu dari beberapa bentuk tari yang bersumber dari wayang wong di Keraton Yogyakarta. Tari ini menggambarkan seorang raja atau kesatria yang sedang jatuh cinta kepada seorang wanita yang menjadi kekasihnya. Di dalam adegan jejeran wayang wong lakon Sri Suwela di Keraton Yogyakarta terdapat komposisi tari nglana, kemudian dilepas tersendiri menjadi bentuk tari tunggal.

Penulisan ini untuk mengetahui pengaruh wayang wong di Keraton Yogyakarta terhadap tari Klana Sri Suwela, dan membahas penerapan konsep jogèd Mataram dalam tari Klana Sri Suwela. Penulisan ini menggunakan dua pendekatan yang melatarbelakanginya, yaitu pendekatan tekstual dan pendekatan konstektual. Secara tekstual pemberlakuan tari berkaitan dengan bentuk, struktur, dan gaya tarinya. Secara kontekstual pemberlakuan tari sebagai teks kebudayaan, dapat ditelaah melalui kedudukannya di masa sekarang kaitannya dengan catatan yang ada di masa lampau.

Pencermatan tari Klana Alus Sri Suwela melibatkan unsur-unsur yang mendasari penjelasan tentang konsep tari Jawa gaya Yogyakarta. Unsur- unsur wiraga, wirama, dan wirasa merupakan unsur-unsur yang sangat penting dalam menjelaskan konsep tari Jawa. Di dalam pelaksanaan menari unsur wiraga, wirama, dan wirasa harus dibekali suatu ilmu yang disebut jogèd Mataram. Jogèd Mataram sekarang ini dikenal dengan konsep jogèd Mataram, terdiri dari empat unsur yaitu, sawiji, greged, sengguh, dan ora mingkuh. Bentuk dan struktur tari mengacu pada tata hubungan dalam struktur tari, sistem pelaksanaan teknik dan cara bergerak dalam bagian-bagian tubuh penari sebagai perwujudan tari yang utuh.
\end{abstract}

Kata Kunci: Konsep Joged Mataram

The Yogyakarta style of Klana Alus Sri Suwela dance is recognized the refined male character dances which can be observed through the movement volume and its character visualization. The Yogyanese style of Klana Alus Sri Suwela dance is one of several dances which were based on Wayang Wong in Yogyakarta Palace. The dance illustrates a king who falling in love with his beloved woman. In the jejeran scene of wayang wong episode in Sri Suwela in Yogyakarta Palace, there is a nglana dance composition, which later being performed separately to a solo dance.

The object of the study is to find the influence of Yogyakarta Palace's Wayang Wong on Klana Alus Sri Suwela dance, and discussing the application of jogèd Mataram concept in Klana Alus Sri Suwela dance. The study used textual and contextual approach. In textual approach, the conduct of the dance is being studied concerning the type, structure, and style of the dance. In contextual approach, the dance taken as a cultural reading is being studied in its present position in relation with the past documentation.

Klana Alus Sri Suwela dance is a Javanese dance; therefore the observation on the dance concerns the elements which become the basic in describing the concept of Yogyakarta style of Javanese dance. Wiraga, wirama, and wirasa are important elements in describing Javanese dance concept. In the dance performing, those elements must be supported by a skill known as jogèd Mataram. Jogèd Mataram, which is now being recognized as jogèd Mataram concept, consists of four elements, sawiji, greged, sengguh, and ora mingkuh.

The form and structure of dance are referring to the relationship in dancing structure, dancing technique and how the movements of the dancer's body as a realization of the whole of dance. Accordingly, the tri wira (wiraga, wirama, wirasa) concept serves as the technique and outline, and the jogèd Mataram serve as the 
content. Therefore, in order to perform a dance and play the role well, a dancer should master the three elements of the tri wira concept infused by jogèd Mataram concept.

\section{Latar Belakang Masalah}

\begin{abstract}
Beberapa bentuk tari tradisi gaya Yogyakarta, yang sampai dewasa ini mendapat pemeliharaan cukup baik di lingkungan istana maupun di luar istana Yogyakarta adalah wayang wong gaya Yogyakarta. Bentuk penyajian yang lain dapat disebut antara lain beksan Lawung, Guntur Segara, Eteng, beberapa genre Bedaya dan Srimpi. Hampir semua jenis penyajian di atas merupakan cabang-cabang seni pertunjukan yang hidup dan berkembang di lingkungan istana Yogyakarta (Edi Sedyawati, 1981:1). Lingkungan istana merupakan salah satu faktor yang cukup kuat untuk mempengaruhi bentuk-bentuk keseniannya. Oleh sebab itu, keberadaan kesenian dan perkembangan selalu terikat adat dan norma-norma dari lingkungan istana itu sendiri. Hal itulah yang menjadikan tari tradisi istana selalu dipegang kuat, baik dalam penggarapan pola-pola tari yang lahir kemudian di lingkungan istana maupun bentuk-bentuk tari yang lahir di luar istana tetapi mengacu pada gaya istana. Perumusannya menjadi begitu melekat dengan pola-pola baku yang mendasari struktur dan bentuk gerak yang berorientasi pada ciri-ciri kraton sentris (R.M. Wisnoe Wardhana, 1981:36).
\end{abstract}

Tari Klana adalah salah satu bentuk tunggal putra yang terdapat di istana-istana Jawa, dalam hal ini Kasultanan Yogyakarta, Kasunanan Surakarta, Mangkunegaran, dan Pura Pakualaman. Telah diketahui bahwa, keempat kerajaan itu bermula dari satu sumber yaitu kerajaan Mataram. Karena adanya intrik politik pada waktu penjajahan Belanda, Kerajaan Mataram terpecah menjadi empat. Empat istana tersebut semuanya mempunyai bentuk tari Klana. Bentuk tari Klana dari masing-masing istana memiliki ciri sendiri-sendiri, baik pada gaya, kualitas gerak maupun pembentukannya (masing-masing istana memiliki gaya tari yang berlainan). Kasultanan Yogyakarta disebut gaya Yogyakarta, Kasunanan Surakarta disebut gaya Surakarta, Pura Mangkunegara dengan gaya Mangkunegaran, dan Pura Pakualaman dengan gaya Pakualaman.

Robert Redfield membedakan kebudayaan menjadi dua, yaitu tradisi besar dan tradisi kecil. Ungkapan ini untuk menyebut kebudayaan tinggi dan kebudayaan rendah, atau kebudayaan klasik dan rakyat. Tradisi besar secara sadar diolah dan diwariskan di dalam istana, sedangkan tradisi kecil sebagian besar diterima sebagaimana apa adanya dan tidak terlalu cermat dipertimbangkan pembaharuannya. Kedua tradisi itu saling ketergantungan, tradisi besar dan kecil dipikirkan sebagai dua aliran pikiran atau tindakan yang bisa dibedakan, namun saling mempengaruhi pada yang lain (Robert Redfield, 1985:57-59). Tari Klana gaya Yogyakarta dapat dikatakan sebagai refleksi dari konsep di atas. Tari Klana memang lahir di dalam istana, tetapi berkembang di luar tembok istana, dan mendapat perkembangan tari yang lain seperti tari tlèdhèk yang terdapat pada vokabuler gerak tlèdhèkan pada irama tiga gending pengiringnya.

Tari Klana Alus Sri Suwela gaya Yogyakarta yang dikenal sampai sekarang ini merupakan tipe tari putra dengan karakter halus. Penyebutan yang demikian ini, dapat dilihat dari volume gerak dan visualisasi karakternya. Soedarsono menjelaskan tentang seni Klana sebagai berikut:

"Komposisi tari putra tunggal, gaya Surakarta dan gaya Yogyakarta yang menggambarkan seorang kesatria sedang jatuh cinta" (R.M. Soedarsono, 19771978:93).

Mengacu pada pendapat tersebut, komposisi tari ini penuh dengan gerak yang menggambarkan seorang pria yang sedang berdandan, merayu kekasihnya yang seolaholah berada di hadapannya dan sebagainya. Tari ini dapat ditarikan dengan tipe tari putra halus atau gagah, dapat pula bertopeng atau tidak memakai topeng. Dalam penjelasan yang terinci, Soedarsono menjelaskan tentang tipe Klana Alus sebagai berikut: 
"Jenis tari Klana Alus yang ditarikan dengan tipe tari putra halus gaya Yogyakarta, menggambarkan seorang kesatria sabrangan (seberang) yang sedang jatuh cinta" (Soedarsono 19771978:94).

Sesuai dengan pandangan di atas, maka visualisasi tokoh pada tipe tari Klana Alus merupakan penggambaran keagungan seorang raja atau kesatria dari negeri seberang yang bersumber pada cerita epos Mahabarata. Figur raja adalah manifestasi penguasaan mayapada dan alam astral yang hadir. Sebutan Klana adalah tokoh besar pengelana yang datang dari luar, yang dapat berkonotasi pada manusia, bercita-cita tinggi/kadang-kadang berasosiasi pada romantisme, suatu kegandrungan, yang tidak mesti bersifat erotis atau cenderung seksi, melainkan pada idealisme yang estetis (Wisnoe Wardhana, 1981:36).

Tari Klana Alus Sri Suwela bersumber pada wayang wong di Kraton Yogyakarta. Wayang wong secara umum sebagai dramatari yang berarti pertunjukan wayang yang ditarikan oleh aktor manusia (Jeennifer Lindsay, 1991:897). Istilah wayang wong dari segi genre dapat mengacu pada semua dramatari, tetapi kini biasanya khusus dramatari tanpa topeng yang bersumber dari wiracarita Ramayana dan Mahabarata, dengan dialog di dalamnya dibawakan sendiri oleh para penari dan mengikuti rancangan pertunjukan wayang kulit. Soedarsono menyebutkan bahwa wayang wong merupakan sebuah genre tari yang dapat dikategorikan sebagai pertunjukan total (total theatre) yang di dalamnya tercakup seni tari, seni drama, seni sastra, seni musik, dan seni rupa (Soedarsono, 2003:3).

Mengacu pandangan di atas, istilah wayang wong dapat ditunjukkan pada dua jenis wayang wong yang sampai sekarang hidup, yakni wayang wong hiburan yang komersial dan wayang wong Kraton Yogyakarta. Wayang hiburan yang komersial hidup dan berkembang di Surakarta seperti wayang wong Sriwedari. Adapun wayang wong Kraton Yogyakarta hidup dan berkembang di Kraton Yogyakarta dan di beberapa organisasi tari atau sanggar tari besar di lingkungan Kraton Yogyakarta. Satu hal yang memberi ciri perbedaan wayang wong Kraton Yogyakarta dengan wayang wong komersial adalah, segi formalitas penyajiannya, pada aspek tari, busana, skala pertunjukan, dan struktur dramatik yang mendekati pada pertunjukan wayang kulit (Lindsay, 1991:89). Sampai dengan pandangan ini, suatu pengantar dari sebuah pertunjukan wayang wong di Kraton Yogyakarta diharapkan mampu memperjelas terbentuknya tari Klana Alus Sri Suwela gaya Yogyakarta.

Wayang wong gaya Yogyakarta diciptakan oleh Sri Sultan Hamengku Buwana I (1756-1796) dan mengalami era keemasan pada masa pemerintahan Sri Sultan Hamengku Buwana VIII (1921-1939). Pada masa pemerintahan Hamengku Buwana VIII hampir setiap pertunjukan wayang wong memakan waktu berhari-hari. Pertunjukan yang diselenggarakan di Tratag Bangsal Kencana dari pagi hari sampai sore hari. Salah satu pertunjukan wayang wong dengan durasi waktu agak panjang terjadi di tahun 1923, yakni mengetengahkan cerita Jaya Semedi kemudian dilanjutkan dengan cerita Sri Suwela. Pertunjukan ini memakan waktu empat hari, dari tanggal 3 sampai 6 September 1923 (Soedarsono, 2000:19). Cerita Sri Suwela merupakan cerita carangan dari wiracarita Mahabarata. Cerita ini menggambarkan tentang Dewi Pertalawati, istri Werkudara yang mencari suaminya dengan menyamar sebagai seorang raja tampan dari negeri Parangretna bernama Sri Suwela. Di dalam penyamarannya Sri Suwela ingin meminang Werkudara atau Bima, seorang kesatria gagah perkasa yang dianggap seorang putri sangat cantik dengan sebutan Mas Ayu Werkudara. Hal ini merupakan suatu yang tidak wajar, maka lamaran Sri Suwela ditolak oleh raja Amarta Prabu Puntadewa. Terjadilah peperangan, para Pandawa tidak ada yang dapat mengalahkan Sri Suwela. Setelah melihat Prabu Kresna raja dari Dwarawati membawa senjata Cakra, Sri Suwela menjadi lemas dan akhirnya berubah ke wujud aslinya yaitu Dewi Pertalawati.

Tari Klana Sri Suwela, bersumber pada wayang wong gaya Yogyakarta dengan lakon Sri Suwela. Dalam salah satu adegan jejeran wayang wong Sri Suwela ini terdapat bentuk tari Klana Alus Sri Suwela. Bentuk tarinya 
masih sangat lengkap, yang memuat unsurunsur kandha, pocapan, dan ngrungruman (Kagungan Dalem Serat Kandha Ringgit Tiyang Lampahan Sri Suwela, 1923). Bentuk tari Klana dalam adegan jejeran wayang wong itulah kemudian diambil dijadikan bentuk tari tunggal dengan nama tari Klana Alus Sri Suwela. Setelah menjadi bentuk tari tunggal ada perubahan-perubahan yang terjadi antara lain unsur-unsur kandha, pocapan, dan ngrungruman sudah tidak dikemukakan lagi.

Informasi tentang latar belakang terbentuknya tari Klana Alus gaya Yogyakarta menyebutkan bahwa tokoh Sri Suwela merupakan sosok raja besar yang mengilhami karakter tari Klana Alus gaya Yogyakarta. Di samping itu, bentuk-bentuk kandha, pocapan, dan ngrungruman yang sudah tidak diketemukan pada bentuk tari Klana Alus sekarang, lebih merupakan penerjemahan yang digantikan dalam bentuk simbol gerak. Komposisi gerak (sekaran) akan dapat membuktikan kesejajaran pada bentuk tari Klana Alus Sri Suwela mampu mempengaruhi bentuk tari Klana Alus gaya Yogyakarta dewasa ini (Wisnoe Wardhana, 1981:79).

Berkenaan dengan cerita (lakon) Sri Suwela dalam wayang wong di Kraton Yogyakarta, maka kehadiran tokoh Sri Suwela dalam pertunjukan wayang wong mempunyai keistimewaan tertentu. Seorang yang akan memerankan tokoh Sri Suwela harus menguasai teknik gerak tari putra halus dan tari putri. Selain itu karakternya sebagai seorang raja yang agung tetapi memiliki sifat keputri-putrian. Peneliti sangat tergoda untuk mengkaji lebih jauh tentang Klana Alus Sri Suwela hubungannya dengan wayang wong Yogyakarta dan sebagai tari tunggal. Hal yang penting mendasari pemahaman peneliti adalah melihat proses identifikasi diri Dewi Pertalawati sebagai tokoh Sri Suwela raja seberang dari negeri Parangretna dalam sajian pertunjukan wayang orang di kraton Yogyakarta, telah mengalami perubahanperubahan dalam proses perilaku sebagai tari tunggal, termasuk pemerannya.

\section{Dasar Konsep Joged Mataram}

\section{A. Tiga Unsur Tari}

Tari adalah suatu bentuk pernyataan imajinatif yang tertuang melalui kesatuan simbol-simbol gerak, ruang, dan waktu (Bambang Pudjasworo, 1982:61). Tari dalam perwujudannya senantiasa harus dihayati sebagai bentuk kemanunggalan dari suatu pola imajinatif gerak, ruang, dan waktu yang dapat dilihat dengan kasat mata. Bentuk kemanunggalan antara pola imajinatif dengan pola kasat mata itu dapat dikatakan bahwa tari merupakan suatu bentuk pernyataan ekspresi (jiwani), bentuk pernyataan ilusi, dan sekaligus merupakan bentuk pernyataan rasional manusia. Gerak, ruang, dan waktu dihadirkan sebagai sebuah satu kesatuan yang utuh yang mewakilinya.

Konsep dasar dalam tari secara universal adalah gerak, ruang, dan waktu. Tari Jawa gaya Yogyakarta juga mempunyai konsep dasar yang relatif universal pula. Perlu diungkapkan pernyataan salah satu tokoh tari gaya Yogyakarta, yakni B.P.H. Suryodiningrat. Dalam salah satu uraiannya dinyatakan:

\section{Ingkang dipoen wastani djogèt punika ébahing sadaja sarandoening badan, kasarengan oengeling gangsa, katata pikantoek wiramaning gendhing, djoemboehing pasemoen, kaliyan pikadjenging djogèt.}

(yang dimaksud tari adalah gerak seluruh anggota badan, yang diiringi dengan musik (gamelan) dikoordinasikan menurut irama gamelan, kesesuaian dengan sifat pembawaan tari serta maksud tarinya (B.P.H. Suryodiningrat, 1934:3).

Menurut batasan tari di atas, maka secara konsepsional yang dimaksud tari (tari Jawa), senantiasa harus berpijak 
pada tiga aspek pokok ialah wiraga, wirama, dan wirasa. Wiraga adalah konsep gerak, wirama merupakan konsep irama, dan wirasa adalah konsep penjiwaan. Konsep wiraga, wirama, dan wirasa (3 w) masih terdapat lagi konsep yang lebih berupa aturan-aturan dan kaidah yang terangkum dalam pathokan baku dan pathokan tidak baku.

\section{Wiraga}

Wiraga adalah seluruh aspek gerak tari, baik berupa sikap gerak, pengulangan tenaga serta proses gerak yang dilakukan penari, maupun seluruh kesatuan unsur dan motif gerak (ragam gerak) tari yang terdapat di dalam suatu tari. Wiraga merupakan konsep gerak dalam tari gaya Yogyakarta. Konsep wiraga ini ada beberapa kaidah atau aturan yang harus betul-betul dipatuhi oleh penari dalam melakukan gerak tari. Hal ini dikarenakan di dalam tari gaya Yogyakarta ada faham benar dan salah yang diukur dengan kemampuan penari dalam menerapkan kaidah-kaidah atau aturan-aturan yang ada. Hal ini bertolak belakang dengan sisi batinnya tari gaya Yogyakarta, karena faham yang ada adalah sudah mampu dan belum mampu atau sudah bisa dan belum bisa.

Keindahan dari sebuah tari hanya dapat dipandang ketika tari itu ditarikan atau saat tarian itu berlangsung lewat penarinya. Keindahan itu dapat dipandang dari dua aspek yang saling terkait yaitu pelaku atau penari dengan desain geraknya. Keindahan dari seorang penari dapat dikatakan indah apabila seorang penari secara optimal telah mampu menerapkan kaidah-kaidah atau aturan-aturan yang ada. Kaidahkaidah yang ada merupakan landasan utama dalam teknik tari gaya Yogyakarta. Kaidah-kaidah atau aturan-aturan dalam tari klasik gaya Yogyakarta dapat dikelompokkan menjadi dua, yaitu kaidah baku atau pathokan baku dan kaidah tidak baku atau pathokan tidak baku yang nanti akan dijelaskan secara rinci di bagian berikutnya.

Wiraga dalam tari Klana Alus Sri Suwela gaya Yogyakarta pada prinsipnya tetap mengacu pada aturan atau pathokan tari putra alus gaya Yogyakarta. Pelaksanaannya dalam sebuah tari Klana dapat dibedakan menjadi 3 bagian. Bagian pertama maju gendhing merupakan bagian yang memiliki kesan agung, dan berwibawa. Wiraga yang dimaksud pada bagian ini ialah ragam gerak tari yang dipakai penuh dengan kekuatan, ketegasan, dan kedinamisan. Di bagaian kedua pada muryani busana memiliki kesan prenèsan, sengsem, keceriaan, kegembiraan, dan percaya diri. Wiraga di bagian ini apabila dikaitkan dengan ragam gerak tari penuh dengan daya pikat atau daya tarik kelembutan, penuh tekanan, keluwesan, kelenturan, dan kedinamisan. Oleh sebab itu dalam sekaran muryani busana banyak wiraga tari putri gaya Yogyakarta dipakai dalam tari Klana Alus Sri Suwela. Contoh nglèrèg, kicat ridhong, usap suryan, kicat ulapulap, kicat tawing, kengser, lèmbèhan asta, dan lain-lain. Wiraga tari putri tersebut telah mengalami distorsi dan stilisasi sehingga diterapkan di dalam tari putra alus tetap kelihatan wiraga tari putra alus. Penerapatan wiraga tari putri dalam muryani busana merupakan pengaruh tari Tledhek dari tradisi kerakyatan. Berbagai ragam tari putri yang diterapkan dalam tari Klana Alus Sri Suwela ialah nglèrèk, srimpet nglawé, lampah sekar, lèmbèhan kicat, kicat ridhong, ulap-ulap kicat, ukel tawing kicat, usap suryan kicat, pacak gulu trap tawing dan lainlain. Oleh karena itu penari Klana Alus Sri Suwela yang baik harus menguasai wiraga tari putra alus dan wiraga tari putri gaya Yogyakarta. 


\section{Wirama}

Wirama di sini menyangkut pengertian tentang irama gending, irama gerak, dan ritme gerak. Seluruh gerak (wiraga) harus senantiasa dilakukan selaras dengan wiramanya (ketukan-ketukan hitungan tarinya, kecepatan pukulan balungan suatu gending, dan suasana gendingnya). Unsur wirama ini selanjutnya akan mengatur irama yang harus dimiliki oleh seorang penari. Tari Klana Alus Sri Suwela menggunakan musik gendhing ladrang Sumyar laras pelog pathet barang. Untuk menumbuhkan kesan agung dan berwibawa menggunakan irama dua yang satu gongnya apabila dikaitkan dengan hitungan tari ada tigapuluh tiga hitungan. Irama ini digunakan pada saat maju gendhing dan mundur gendhing. Pada waktu muryani busana yang menunjukkan kegembiraan digunakan irama satu atau lancar apabila dikaitkan dengan hitungan tari satu gongnya ada 16 hitungan. Ada tiga aspek kepekaan dalam wirama yaitu:

a). Kepekaan irama gending

Gending dalam konteks sebagai musik tari merupakan unsur yang sangat penting dan cenderung mendominasi. Gending sangat berpengaruh sekali dalam pembangun pembentuk karakter tari. Penari harus mempunyai kepekaan dan ketajaman untuk dapat selaras dengan irama gending sebagai musik tarinya. Penari harus dapat mengikuti dinamika yang dihasilkan oleh gending pengiringnya. Ada beberapa bagian pada gending yang harus diketahui oleh seorang penari, pada bagian ini biasanya sebagai pathokan untuk dimulai dan diakhirinya sebuah motif gerak. Titik-titik tekanan itu adalah kenong, kempul, kethuk dan gong. Hitungan merupakan kelipatan empat atau delapan. Sesuai dengan tradisi tari dalam tari Jawa baik gaya Yogyakarta maupun gaya Surakarta. Untuk memudahkan hitungan gending kaitannya dengan hitungan gerak tari maka digunakan ketentuan hitungan satu sampai delapan (1-8).

b). Kepekaan irama dalam hubungannya dengan gerak, yaitu ketajaman rasa untuk dapat mengorganisasi anggota tubuh dengan tempo, seperti yang dihasilkan oleh musik. Keteraturan dalam bergerak akan menghasilkan kesan gerak yang mengalir (mbanyu mili). Seorang penari harus terlebih dulu menguasai irama gerak yang disesuaikan dengan tempo yang ditimbulkan oleh gending pengiringnya.

c). Kepekaan terhadap irama hubungannya dengan kemampuan penari mengorganisasikan tubuhnya, untuk digerakkan sesuai dengan kaidah-kaidah dan motif gerak yang ada. Kepekaan ini menuntut adanya ketajaman rasa dalam mengambil jarak antara anggota tubuh. Kaidahkaidah yang ada, dimaksudkan untuk mendapatkan suatu pertunjukan tari yang dibawakan penarinya dengan kesan pantes, luwes, resik, mungguh, dan mrabu.

Pantes adalah serasi, sesuai dengan proposi. Ada dua kriteria untuk dapat disebut pantes dalam tari putra halus gaya Yogyakarta. Pertama, pantes dalam tari putra halus gaya Yogyakarta sangat terkait dengan kemampuan penari. Terkait dengan adanya istilah pantes dan sebagainya di keraton Yogyakarta terdapat istilah penari wiraga dadi. Istilah itu untuk menyebut penari yang dianggap terampil. 
Pada tingkatan ini penari diberi kebebasan untuk menyimpang dari pathokan-pathokan baku gaya Yogyakarta untuk kemudian disesuaikan dengan interpretasinya. Hal ini dilakukan oleh seorang penari untuk mendapatkan kesan pantes. Kedua, pantes dikaitkan dengan karakter yang diperankan atau dibawakan. Perwatakan tari gaya Yogyakarta dikenal dengan istilah wanda, yang diambil dari peristilahan wayang kulit, yang berarti bentuk raut muka dan bentuk tubuh yang menggambarkan

perwatakan/karakter tertentu. Kaitannya dengan pantes adalah pemeranan penari berdasarkan kesesuaian bentuk tubuh dan karakter penari dengan wanda peran yang akan dibawakan. Ketrampilan menjadi kurang penting karena yang dipentingkan adalah kesesuaian bentuk tubuh dengan raut muka penari dengan wanda wayang yang akan dibawakan.

Luwes adalah suatu sifat pembawaan yang tidak mudah diajarkan. Penari dapat dikatakan luwes apabila dalam menari ia nampak wajar, tidak kaku, geraknya enak dilihat, lancar, mengalir sesuai dengan irama gamelan, tidak ada kesan dipaksakan, geraknya serius dan sungguh-sungguh tetapi tidak kelihatan tegang. Resik adalah bisa diartikan bersih. Untuk mendapatkan kesan bersih, seorang penari harus selalu mengontrol dengan cermat pada setiap geraknya. Gerakan harus dilakukan dengan rinci, dan cermat serta mengetahui kaidah-kaidah yang berlaku, hasil ini bisa didapatkan bila seorang penari sudah mengetahui teknik tari dengan baik dan mempunyai kepekaan akan rasa gending, irama dan gerak yang telah dijelaskan sebelumnya. Mungguh adalah kesan yang didapatkan dari seorang penari yang membawakan tariannya (perannya) dengan penuh penghayatan. Bagi penari yang sudah tidak berfikir tentang teknik tari atau hafalan, maka penari akan dapat lebih konsentrasi pada penghayatan karakter geraknya dan pada giliranya dapat meningkatkan rasa percaya diri. Mungguh juga dapat berarti penari dapat dengan tepat dan cermat membawakan perannya atau tariannya.

Mrabu adalah kesan

berwibawa, agung, dan berkarisma. Kesan seperti itu sifatnya agak khusus, karena tidak semua peran dapat mengisyaratkan kesan ini. Kesan ini hanya dapat diperoleh dari peran/tokoh yang relatif baik, misalnya seorang raja, seperti tari Klana Alus Sri Suwela gaya Yogyakarta yang mengisahkan seorang Raja Parang Retna yang sedang jatuh cinta. Banyaknya tuntutan dalam aspek teknik dan penjiwaan dalam tari klasik gaya Yogyakarta, untuk dapat tampil dengan sempurna dalam sebuah pertunjukan dibutuhkan seorang penari yang mempunyai kemampuan teknik dan penguasaan karakter yang baik.

\section{Wirasa}

Wirasa adalah hal lain banyak bersangkut paut dengan masalah isi dari suatu tari. Masalah isi selalu banyak berhubungan dengan pengertian-pengertian yang terdapat dalam jogèd Mataram untuk tari gaya Yogyakarta dan Hasta Sawanda untuk tari gaya Surakarta. 
Pada dasarnya penerapan wiraga dan wirama tarinya harus selalu mengingat akan arti, maksud, dan tujuan dari tarian tersebut, sehingga seorang penari akan tampil dengan penjiwaan secara utuh yang sawiji, greged, sengguh, dan ora mingkuh. Wirasa merupakan aspek penjiwaan dalam tari gaya Yogyakarta. Aspek penjiwaan ini tidak terlepas dari wiraga, wirama, wirasa yang nantinya akan terakumulasikan menjadi satu konsep yang disebut jogèd Mataram yang terdiri dari sawiji, greged, sengguh, dan ora mingkuh. Semula konsep jogèd Mataram disampaikan secara lisan oleh guru tari ketika mengajarkan tari. Konsep jogèd Mataram mulai tersebar kepada masyarakat para penari semenjak tari gaya Yogyakarta dapat keluar dari tembok istana, yaitu semenjak berdirinya organisasi tari Kridha Beksa Wirama (K.B.W.) pada tahun 1918. Konsep jogèd Mataram ini dipopulerkan oleh G.B.P.H. Soeryobronto, seorang pangeran dan penari andal Keraton Yogyakarta. Konsep jogèd Mataram sekarang telah sangat memasyarakat di komunitas tari. Sungguhpun, pada awalnya konsep ini merupakan sesuatu yang rahasia, yang tidak boleh diajarkan kepada sembarang orang dan hanya yang boleh diajarkan kepada penari yang telah dipandang oleh guru menguasai tentang seni kebatinan. Hal ini tersurat dalam tembang sinom yang terdapat dalam Babad Prayud, sebagai berikut:

Jeng sultan malih ngendika,

Kulup Tirtakusumèki,

Iku beksanmu madura,

Iya kurang sereng kedhik,

Beksanira mentawis,

Apa wis duwe sirèku,

Nembah Tirtakusuma,

Inggih putra padukaji,

Ingkang mulang leres lepatipun

kilap,
Jeng sultan tindak saksana,

Kulup mèluwa mami,

Tumut manjing prabayasa,

Mangalèring jamban prapti,

Payu lekasa kedhik,

Nembang sigra beksanipun,

Lagyantuk tigang gongan,

Ya uwis iku nak mami,

Isih wutuh iya beksanmu

mataram,

Aja murukaken sira,

Ing beksa mataram iki,

Tur sembah Tirtakusuma,

Putra dalem Sri Bupati,

Kados paduka meling,

Arungit mèsem ngendika,

Iya pada lawan mami,

Sareng mijil Sultan lan

Tirtakusuma

(Soedarsono, 2000:109).

(Sri Sultan bersabda,

Putraku Tirtakusuma,

Itu tarimu madura,

Ia kurang galak sedikit,

Tarimu mataram,

Apa telah kau miliki,

Menjawab Tirtakusuma,

Ya putra baginda raja,

Yang mengajak hamba tidak

tahu benar tidaknya,

Sri sultan berjalan cepat,

Putraku ikutilah saya,

Ikut masuk ke prabayasa,

Ke utara smapai ke

permandian,

Marilah cepat sedikit,

Menyanyi segera menari,

Baru dapat tiga gongan,

Ya sudahlah itu putraku,

Masih utuh tarianmu mataram.

Janganlah kau mengajarkan,

Tirtakusuma ini,

Bersembahlah Tirtakusuma,

Putranda Sri Bupati,

Seperti yang paduka katakan,

Sangat sukar tari mataram,

Sultan tersenyum bersabda, Ya sama dengan saya, 
Bersama keluar sultan dan Tirtakusuma).

Cuplikan tembang sinom di atas tersirat bahwa, jogèd Mataram adalah sesuatu yang rahasia, yang tidak boleh diketahui atau diajarkan kepada sembarang orang. Konsep ini menjadi sesuatu yang sangat dirahasiakan sampai kurang lebih tahun 1918, bersamaan berdirinya suatu organisasi tari di luar keraton. Seperti diungkapkan oleh G.B.P.H. Soeryobrongto bahwa jogèd Mataram adalah kewajiban atau seni penjiwaan dari tari klasik gaya Yogyakarta (Soeryobrongto, 1981:88). Konsep jogèd Mataram sering juga disebut ilmu jogèd Mataram yang diciptakan oleh Sri Sultan H.B I (1755-1792). Pada waktu itu tidak semua guru mengetahui mengenai konsep jogèd Mataram, sehingga tidak mengherankan apabila banyak murid tidak mengetahuinya. Namun demikian murid yang betul-betul memiliki bakat dan sudah memperoleh kematangan lahir batin, oleh guru yang terpercaya dapat diperkenankan mendalami ilmu jogèd Mataram.

\section{B. Filosofi Joged Mataram}

Ilmu jogèd Mataram terdiri dari 4 (empat) unsur yaitu: sawiji, greged, sengguh, dan ora mingkuh dengan penjelasan sebagai berikut:

a). Sawiji

Sawiji adalah suatu konsentrasi penuh atau total dari seorang penari di atas pentas, akan tetapi konsentrasi tersebut tidak sampai menimbulkan ketegangan jiwa. Konsentrasi adalah suatu kemampuan seseorang penari untuk mengerahkan semua kekuatan pikiran pada suatu sasaran yang jelas. Penari harus dapat atau mampu mentransformasikan dirinya pada suatu peran yang harus dibawakan atau dijalani. Konsentrasi penari tidak terikat oleh perasaanperasaan yang aktual. Penari bebas dari kesadaran objektif yang aktual atau praktik perbuatan sehari-hari. Penari tidak mengekspresikan dirinya, tetapi mengkomunikasikan bentuk-bentuk perasaan melalui penyajian simbolis. Konsentrasi total bukan berarti penari menjadi tidak sadarkan diri, namun peleburan seorang penari dengan karakter tari yang harus dibawakan.

Sawiji dalam tari Klana Alus Sri Suwela dimengerti bahwa penari sudah tidak memikirkan tentang hafalan maupun yang lain. Pikiran dan perasaan sudah memahami apa yang harus dilakukan dan apa saja yang akan dilakukan penari di atas pentas. Mulai penari berjalan masuk arena pentas, maka bukan dirinya lagi tetapi peran apa yang dibawakan. Semuanya itu dari dalam jiwa mengalir, apalagi dengan adanya bunyi instrumen atau musik, maka kepekaan penari terhadap peran yang dibawakan akan semakin meningkat.

b). Greged

Greged adalah suatu semangat yang membara yang ada pada jiwa seorang penari di atas pentas. Semangat yang dikerahkan itu tidak boleh dilepaskan begitu saja, tetapi harus ditekan atau diarahkan pada suatu yang normal atau wajar. Semangat seorang penari harus dikendalikan, yang pada gilirannya tidak akan berkesan atau kelihatan kasar. Greged merupakan pembawaan dari seorang penari. Unsur ini tidak dapat diajarkan/dilatih oleh orang lain atau guru. Guru yang baik harus dapat mengetahui bila murid memiliki greged atau tidak. Apabila seorang penari mempunyai greged, maka guru tinggal mengarahkan ke arah yang benar. Penari yang baik harus memiliki greged, apabila ia tidak memiliki greged akan mengalami 
kesulitan dalam menyalurkan dinamika dalam diri karakter tari yang dibawakan. Penari yang memiliki greged yang baik, walaupun dalam keadaan sikap diam telah menimbulkan kesan adanya gerak di dalam jiwa dan karakter yang dibawakan (Soeryobrongto, 1981:91).

Greged dalam tari Klana Alus Sri Suwela agak dikurangi terutama pada waktu sekaran muryani busana. Greged di dalam muryani busana memiliki rasa prenèsan, tetapi masih di dalam batas aturanaturan tari putra alus yang berlaku. Penonjolan pada waktu melakukan sekaran muryani busana adalah tekanan-tekanan atau aksi-aksi agar memiliki daya tarik atau daya pikat terhadap apa yang dilakukan penari Klana Sri Suwela.

\section{c). Sengguh}

Sengguh adalah percaya pada diri sendiri yang tidak mengarah pada kesombongan penari di atas pentas. Percaya diri sendiri sangat penting bagi seorang penari. Penari yang telah tampil di atas pentas, harus percaya dengan sepenuh hati bahwa apa yang ditampilkan atau ditarikan adalah baik, dan orang lain atau penonton dapat menikmati dengan baik juga. Jadi seorang penari harus menjadi satu kesatuan dengan tarinya. Seorang penari tampil di atas pentas bukan sebagai dirinya sendiri, tetapi ia membawakan misi untuk menyampaikan sesuatu kepada penonton atau penikmatnya. Sikap semacam ini harus diyakini, sehingga ia memiliki kepercayaan pada diri penari. Kepercayaan ini dapat menimbulkan sikap yang meyakinkan, pasti, dan tidak raguragu dalam bahasa Jawa mbedhedheg (perasaan yang meluap-luap tetapi terkendali) (Soeryobrongto, 1981:92).

Sengguh dalam pembawaan tari Klana Alus Sri Suwela adalah merasa mampu, merasa tampan, merasa gumagus, merasa lebih dari yang lain atau dirinya tak ada yang menyamai. Ada rasa sedikit kongas, tetapi semua itu tetap terkendali sehingga antara gerak yang dilakukan dengan rasa gerak dari dalam diri penari akan mengalir sejalan dengan nalurinya.

d). Ora Mingkuh

Ora mingkuh adalah pantang mundur atau tidak takut menghadapi kesukaran-kesukaran. Penari harus memiliki keberanian dalam menghadapi apa saja waktu pentas. Penari harus menepati janji atau kesanggupan dengan penuh tanggung jawab. Suatu keteguhan hati dalam menarikan suatu tarian atau memainkan suatu peran. Keteguhan hati dapat berarti kesetiaan dan keberanian untuk menghadapi situasi apa saja dengan suatu pengorbanan penuh. Suatu contoh apabila seorang penari telah menyanggupi untuk menari, maka walaupun ia dalam keadaan sakit apabila masih dapat menari, ia harus melakukan dengan penuh tanggung jawab. Ora mingkuh diri seorang penari meskipun dalam perjalanan untuk menuju tujuan yang luhur banyak menghadapi rintanganrintangan, akan tetapi seorang penari tidak akan mundur setapakpun.

Ora mingkuh dalam pembawaan tari Klana Alus Sri Suwela penari di atas pentas tanpa pantang mundur dalam menghadapi segala rintangan, tantangan, kesulitan demi tercapainya cita-cita yang diinginkan. Dalam cerita ini digambarkan untuk mencapai tujuan Sri Suwela harus mengembara dan pantang menyerah menghadapi segala musuhnya.

\section{Dasar Pathokan Baku atau Tidak Baku}

Tari gaya Yogyakarta ada dua pathokan atau aturan yang harus ditaati oleh seorang penari dalam melakukan sebuah tarian. 
Pathokan itu adalah pathokan baku dan pathokan tidak baku.

\section{A. Pathokan baku}

Pathokan baku adalah suatu aturan tari gaya Yogyakarta yang mutlak harus ditaati (dilakukan) bagi seorang penari, baik putra maupun putri yang ingin mencapai tingkat optimal dalam seni tarinya. Berikut ini akan dikemukakan penjelasan terperinci mengenai pathokan baku.

1. Sikap badan (deg)

Sikap badan penari ketika menari harus selalu kelihatan baik apabila dipandang dari segala arah. Badan penari harus selalu tegap (ndegèg). Sikap tegap yang dimaksud adalah tulang belakang (columna vertebrae) berdiri tegak, tulang belikat (scapula) datar (rata), bahu (humeri) membuka, tulang rusuk (costae) diangkat, dada (thorax) dibusungkan, dan perut (abdomen) dikempiskan. Langkah yang harus diambil oleh seorang penari untuk mendapatkan sikap dan gerak badan seperti di atas adalah dengan jalan menarik napas panjang sampai badan dalam posisi seperti yang dimaksud, kemudian napas dikembalikan, akan tetapi tidak boleh mengubah posisi sikap badan. Selanjutnya seorang penari bernafas seperti biasa. Sikap badan semacam ini harus dipertahankan selama menari, walaupun penari di atas pentas dalam keadaan diam, tidak bergerak. Sikap badan seperti itu harus dilakukan dari awal masuk pentas sampai selesai menari dan meninggalkan tempat pentas.

2. Sikap dan gerak kaki

Bagian kaki (metatarsus) penari ini dapat dibagi menjadi dua bagian yaitu bagian tungkai atas (femur) dan jari-jari kaki (phalanges). Posisi kaki dengan ketentuan sebagai berikut:
- pupu mlumah/tungkai atas (femur) terentang

- dhengkul megar/lutut (patella) membuka

- $\quad$ suku malang/kaki (metatarsus) melintang

- driji nylekenthing/jari-jari kaki (phalanges) diangkat ke atas

\section{Mendhak}

Mendhak adalah posisi tungkai (femur dan patella) yang merendah dengan tekukan lutut (patella). Tekukan lutut (patella) ini dilakukan dalam keadaan tungkai atas (femur) terbuka. Mendhak yang mapan memungkinkan gerakan tungkai (femur, patella, tibia, fibula, ossa tarsalia, ossa metatarsalia, dan phalanges) lebih hidup sehingga tarinya kelihatan ébrah (besar). Ruang geraknya menjadi luas atau dapat dikatakan mengisi ruang. Posisi mendhak walaupun yang merendah tungkai atas (femur dan patella), namun sebenarnya kekuatan atau tekanan gerak terletak pada cethik (pelvis), jadi tekukan lutut (patella) sebagai akibat cethik (pelvis) ditekan ke bawah. Tidak ada ukuran yang pasti seberapa rendah tekukan femur dan patella itu, namun yang jelas tidak terlalu rendah sekali dan tidak terlalu kelihatan tidak merendah. Ukuran untuk mendhak setiap penari berbeda-beda tergantung pada tinggi rendahnya tubuh penari, akan tetapi sikap mendhak itu kelihatan luwes dan tanpa mengganggu dalam melakukan gerak. Posisi mendhak lutut (patella) harus tetap terbuka. Posisi mendhak demikian itu gerak akan lebih nampak kuat. Apabila penari tidak mendhak intensitas gerakan akan kosong dan akan kelihatan lemah. Namun demikian apabila penari terlalu mendhak akan menghasilkan tari yang nampak dipaksakan (ngaya) dan membuang tenaga. Mendhak harus dilakukan tidak kendor, tetapi juga tidak tegang. Jadi mendhak yang benar 
adalah mendhak cethik (pelvis) yaitu merendah sehingga memusatkan gerak pada cethik (pelvis) bukan pada tekukan lututnya (patella).

\section{Sikap tangan}

Lebar tangan (jarak tangan dengan badan) untuk tari putra berbeda dengan tari putri. Untuk tari putra masih dibedakan lagi putra halus dan putra gagah. Untuk tari putra halus jarak tangan dengan badan kurang lebih satu pethènthèngan. Mengukurnya dengan cara menempelkan kedua telapak tangan (ossa metacarpalia) pada pinggang. Ukuran lebar tangan (humerus, ulna-radius, carpalia, metacarpalia, ossa metacarpalia, dan phalanges) ini dipakai semua standar tari halus apapun. Bentuk tangan (humerus, ulna-radius, carpalia, metacarpalia, ossa metacarpalia, dan phalanges) apabila menekuk adalah siku-siku dengan pusat atau tekanan pada pergelangan tangan (capalia). Gerak tangan selalu dipusatkan pada pergelangan tangan (carpalia) sedangkan lengan (humerus, ulnaradius) hanyalah mengikuti. Pemusatan gerak tangan (humerus, ulna-radius, carpalia, metacarpalia, ossa metacarpalia, dan phalanges) pada pergelangan tangan (carpalia) ini dimaksudkan agar posisi tangan dan siku dapat stabil tidak mengembang maupun menguncup (megar-mingkup).

5. Pacak gulu/gerak leher (cervical vertebrae)

Gerak leher (cervical vertebrae) dipusatkan pada tekukan (coklèkan) jiling (cervic), yaitu persendian kepala (cranium) dengan leher (cervical vertebrae) baik untuk tolehan maupun pacak gulu. Gerak demikian itu adalah tidak Dalam gaya Yogyakarta terdapat empat (4) macam pacak gulu yaitu:

1. Pacak gulu baku (pokok) kanan dan kiri (dexter-sinester)
2. Tolèhan kanan dan kiri (dextersinester)

3. Coklèkan kanan dan kiri (dexter-sinester)

4. Gedheg khusus untuk tari putra gagah kanan dan kiri (dextersinester).

6. Gerak cethik (pelvis)

Cethik atau pangkal tungkai atas (pelvis) merupakan bagian yang sangat penting dalam gerak tubuh penari baik ke arah samping maupun ke bawah atau mendhak. Gerak tubuh ke samping baik ke kanan maupun ke kiri (dexter-sinester) yang benar dalam tari gaya Yogyakarta harus dilakukan dengan pemusatan gerak pada pangkal tungkai atas atau cethik (pelvis).

7. Pandangan mata (pandengan)

Pandangan mata dalam tari gaya Yogyakarta dengan ketentuan kelopak mata terbuka, bola mata lurus ke depan menurut arah hadap muka, dan pandangan tajam, dengan jarak kurang lebih 3 kali tinggi badan. Mata seorang penari tidak boleh berkedip-kedip karena akan kelihatan rongeh dan kurang konsentrasi.

\section{B. Pathokan tidak baku}

Pathokan-pathokan baku merupakan pegangan dasar penari pada umumnya yang memiliki keadaan fisik normal atau wajar, serasi, dan bagus. Sering terjadi ada seorang penari yang memiliki beberapa kekurangan dalam fisiknya. Para penari yang memiliki kekurangankekurangan fisik, mereka harus menggunakan pathokan tidak baku atau khusus untuk menutupi kekurangankekurangan tersebut. Pathokan tidak baku ini bukan merupakan pegangan yang dapat dijalankan oleh setiap orang atau penari. Pathokan ini sering disebut pathokan khusus atau pathokan tidak baku atau juga sering disebut pathokan penyesuaian diri. 
1. Luwes

Luwes merupakan sifat pembawaan dari seorang penari. Penari dikatakan luwes apabila kelihatan wajar dan tidak kaku dalam membawakan tariannya. Gerak yang dilakukan tampak lancar, mengalir sesuai dengan irama yang digunakan dan enak dinikmati, tak ada kesan dipaksakan, geraknya serius dan sungguhsungguh tetapi tidak kelihatan tegang (kenceng nanging ora ngecenceng).

\section{Patut}

Patut adalah serasi dan sesuai. Mengingat adanya kekurangankekurangan fisik penari diperbolehkan melakukan gerak yang sedikit agak menyimpang dari pathokan ragam tarinya, menurut selera dan interpretasinya sendiri. Penyimpangan itu diperbolehkan asal guru tari yang bertanggung jawab sudah menilainya patut. Kepatutan ini di dalam wayang wong Kraton Yogyakarta erat sekali hubungannya dengan "wanda" seorang penari. Wanda adalah raut muka yang menggambarkan perwatakan/karakter.

\section{Resik}

Resik dalam tari dapat diartikan bersih atau cermat dalam melakukan gerak. Penari dapat dikatakan bersih apabila dapat menguasai tiga macam kepekaan irama, yaitu kepekaan irama gending, kepekaan irama gerak, dan kepekaan irama jarak. Kepekaan penari terhadap irama ini akan selalu memperhitungkan ketepatan gerak tarinya. Gerakan harus dilakukan dengan cermat dengan mematuhi keharusankeharusan yang berlaku. Hal ini dapat dilaksanakan apabila penari telah menguasai teknik tari dengan baik. Kecermatan ini merupakan perwujudan tari yang tidak berlebihan tetapi juga tidak kurang, sehingga dilakukan dengan tepat dan cermat.

\section{Sistem Penguasaan Teknik Tari}

Penguasaan teknik bagi para penari pada masa lampau dapat ditempuh melalui tiga sistem, yaitu: 1) sistem menirukan; 2) sistem bimbingan guru; 3 ) sistem mandiri. Ketiga sistem tersebut merupakan cara untuk belajar menari sampai kini.

1. Penguasaan teknik menirukan

Sistem ini merupakan latihan tahap elementer/dasar, biasanya sering disebut tayungan. Dengan tayungan penari bisa menirukan penari lain yang ada di depan maupun disampingnya.

2. Sistem bimbingan guru

Sistem ini lebih menekankan adanya bimbingan yang cermat dan rinci, meliputi kemantapan pembentukan sikap (deg); penggalan-penggalan gerak yang benar menurut aturan, dan peningkatan penghayatan karakter gerak melalui penggalan-penggalan gerak menuju keutuhan.

3. Sistem mandiri

Hasrat untuk selalu meningkatkan kemampuan teknik secara mandiri para penari umumnya sangat kuat. Hal ini adanya pengakuan para nara sumber yang tergolong wayang sabet.

\section{Dasar Pola Baku Gerak Tari}

Menurut G.B.P.H. Soeryobronto, ragam tari putra gaya Yogyakarta dibagi menjadi empat, yaitu:

1. Impur: untuk karakter putra halus, menggambarkan watak, sederhana, tidak banyak tingkah dan percaya diri.

2. Kambeng: untuk karakter putra gagah berwatak jujur, sederhana, tidak banyak tingkah dan percaya diri. 
3. Kalang kinantang: untuk karakter putra alus dan gagah, yang memiliki watak keras, banyak tingkah, agak sombong, angkuh, dan dinamis.

4. Bapang: untuk karakter putra gagah yang berwatak kasar, sombong, banyak tingkah, dan kasar tingkah lakunya (Soeryobrongto, 1981:83$88)$.

Keempat ragam pokok tersebut masih memiliki variasi lebih rumit lagi yang berkembang menjadi dua puluh satu ragam tari pada masa pemerintahan $\mathrm{HB}$ VIII.

\section{E. Dasar Pola Irama dan Ritme Gerak Tari}

Ada empat pola pokok irama yang sering digunakan dalam tari Jawa, yaitu:

1) Ganggeng kanyut, adalah irama gerak yang diterapkan untuk tari Bedaya, tari Srimpi, dan tari Luruh alus gaya Surakata. Dalam hal ini, maka akhir dari setiap bentuk motif gerak tarinya secara prinsip harus dilakukan dengan sedikit membelakangi sabetan (pukulan) balungan pada akhir gatra dari suatu gending.

2) Prenjak Tinaji, adalah irama gerak yang diterapkan pada tari alus lanyapan gaya Surakarta. Irama gerak Prenjak Tinaji ini, setiap akhir dari suatu bentuk motif gerak tari harus dilakukan tepat pada sabetan (pukulan) balungan pada akhir gatra dari suatu gending pengiringnya.

3) Banyak Slulup, adalah irama gerak yang diterapkan pada tari gagah dugangan gaya Surakarta. Penggunaan irama gerak ini dalam tari, yaitu setiap akhir dari suatu motif gerak tarinya harus dilakukan dengan sedikit mendahului dari sabetan (pukulan) balungan pada akhir gatra dari gending pengiringnya.

4) Kebo manggah, adalah pola irama gerak tari yang pada lazimnya diterapkan untuk tari gagah, namun khusus untuk karakter raksasa. Secara prinsip setiap akhir dari suatu bentuk motif gerak tari yang berirama gerak kebo manggah, senantiasa harus dilakukan tepat pada sabetan balungan pada akhir gatra dari gending pengiring tarinya. Berdasarkan penjabaran di atas, kirannya pola irama gerak yang sangat mungkin mendekati pola irama pada tari Klana Sri Suwela gaya Yogyakarta adalah pola irama prenjak tinaji. Irama gerak prenjak tinaji, penggunaan tempo dalam setiap ketukan berjarak tetap, akan terasa lebih konsisten (ajeg) dari pada yang dipergunakan dalam irama gerak ganggeng kanyut. Sehubungan dengan hal itu, maka dalam irama prenjak tinaji, penggunaan irama gerak pribadi akan nampak terbatas. Kecepatan gerak dan penggunaan energi pun akan menjadi lebih teratur dan konsisten. Kesan yang dilahirkan dari cara melakukan gerak irama ganggeng kanyut lebih jelas berbeda dengan irama gerak prenjak tinaji, sehingga tari menghadirkan kesan mengalir tetapi tegas.

\section{PENUTUP}

Pengkajian dasar-dasar konsep jogèd
Mataram secara utuh dapat
diimplementasikan melalui struktur, bentuk
gerak, dan teknik menari, serta penjiwaan
dalam membawakan sebuah bentuk tari.
Pengkajian konsep jogèd Mataram dalam tari
gaya Yogyakarta sebenarnya dapat dipandang
sebagai sebuah pemahaman kognitif dan
normatif. Untuk itu, beberapa aspek yang
melatarbelakanginya dapat ditelusuri dari
kaitan tarian tersebut dengan sumber-sumber
tertulis di masa lampau, dan bentuk-bentuk
perkembangannya. Komposisi tari nglana Sri
Suwela yang ada di bagian adegan jejeran
dalam wayang wong lakon Sri Suwela itu
merupakan latar belakang yang terkait
langsung dengan perwujudan seni tari Klana
Alus Sri Suwela gaya Yogyakarta. Struktur
dan bentuk gerak pada peran tokoh Prabu Sri


Suwela menjadi dasar konsepsi pada tarian tersebut.

Kesimpulan dari pengkajian ini bahwa secara konseptual kehadiran bentuk tari dapat dilihat dari wiraga, wirama, dan wirasa yang semuanya terakumulasikan di dalam konsep jogèd Mataram. Jalinan struktur tari Klana Alus Sri Suwela dipengaruhi oleh adegan jejeran nglana pada pertunjukan wayang wong gaya Yogyakarta lakon Sri Suwela. Jalinan keselarasan hubungan itu menyangkut motif gerak dengan pola lantainya, bentuk gerak dengan musik tari, dan irama gerak serta ritme gerak dengan musik tarinya. Pengkajian jogèd Mataram tari Klana Alus Sri Suwela juga bersinggungan dengan keindahan bentuk yang berpola. Hal ini sangat dimungkinkan dari pencermatan total atau wujud unity pada suatu penyajian berupa tari. Pandangan semacam ini dapat disimpulkan pula bahwa tata hubungan yang terdapat di antara pola lantai dengan makna gerak tari, antar elemen-elemen dasar tari yang mendasari konsep jogèd Mataram.

Pengkajian sebuah konsep jogèd Mataram, dalam tari dengan demikian harus ditekankan pada aspek apa saja yang dilihat, dinikmati, dinilai, dan dipahami sebagai suatu keutuhan atau unity tarian tersebut. Pemahaman itu tercipta meliputi wiraga, wirama, dan wirasa yang dijiwai oleh sawiji, greged, sengguh, dan ora mingkuh. Hal ini dapat terlihat pada pola baku gerak tari, pola lantai, urutan gerak, musik tari, tata rias, dan tata busana, serta pola-pola tata hubungan yang melatarbelakangi suatu genre tari.

Berdasarkan uraian di atas, pengkajian tari Klana Alus Sri Suwela gaya Yogyakarta dapat dipahami secara kognitif maupun normatif. Secara normatif, menjelaskan kehadiran tari Klana Alus Sri Suwela tersebut melalui penentuan dan penerapan pola-pola yang diacu sebagai aspek pertunjukan tari. Secara kognitif karena kaitan catatan masa lampau tari Klana Alus Sri Suwela yang melatarbelakangi pembentukan tari tersebut sebagai genre tari tunggal.

\section{DAFTAR RUJUKAN}

Dewan Ahli Yayasan Siswa Among Beksa. 1981. Kawruh Joged Mataram. Dewan Ahli Yayasan Siswa Among Beksa, Yogyakarta.

Kagungan Dalem Serat Kandha Ringgi Tiyang Lampahan Jaya Semedi Kalajengaken Sri Suwela. K.H.P. Kridha Mardawa Kraton Yogyakarta. M.S.W. A4.

Kagungan Dalem Serat Kandha Ringgi Tiyang Lampahan Jaya Semedi Kalajengaken Sri Suwela. K.H.P. Kridha Mardawa Kraton Yogyakarta. M.S.W. A5.

Lindsay, Jennifer. 1991. Klasik, Kitsch, Kontemporer: Sebuah Studi Tentang Pertunjukan Jawa. Gadjah Mada University Press, Yogyakarta

Meri, La. 1975. Komposisi Tari: Elemen-elemen Dasar. Terjemahan Soedarsono. Yogyakarta: Akademi Seni Tari Indonesia Yogyakarta.

Pudjasworo, Bambang. 1982. Dasar-dasar Pengetahuan Gerak Tari Alus Gaya Yogyakarta. Akademi Seni Tari Indonesia Yogyakarta, Yogyakarta.

\section{Studi Analisis Konsep} Estetik Koreografis Tari Bedaya Lambangsari. Akademi Seni Tari Indonesia Yogyakarta, Yogyakarta.

Sedyawati, Edi. ed. 1986. Pengetahuan Elementer Tari dan Beberapa Masalah Tari. Direktorat Kesenian Proyek Pengembangan Kesenian Jakarta, Departemen Pendidikan dan Kebudayaan, Jakarta.

Soedarsono, [R.M] ed. al. 1977. Kamus Istilah Tari dan Karawitan Jawa. Proyek Penelitian Bahasan dan Sastra Indonesia, Jakarta.

.2000. Masa Gemilang dan Memudar Wayang Wong Gaya Yogyakarta. Terawang Press, Yogyakarta

.2003. Seni Pertunjukan dari Perspektif Politik, Sosial, dan Ekonomi. Gadjah Mada University Press, Yogyakarta. 
JOGED

ISSN: $1858-3989$

Soeryobrongto, G.B.P.H. 1981. "Wayang Orang Gagrag Mataram", dalam Fred Wibowo (ed), Mengenal Tari Klasik Gaya Yogyakarta. Dewan Kesenian Propinsi DIY, Yogyakarta.

Sumaryono. 2003. Restorasi Seni Tari dan Transformasi Budaya. Lembaga Kajian Pendidikan dan Humaniora Indonesia, Yogyakarta.

Wardhana, Wisnoe. R.M., 1981. "Tari Tunggal, Beksan dan Tarian Sakral Gaya Yogyakarta", dalam Fred Wibowo (ed), Mengenal Tari Klasik Gaya Yogyakarta. Dewan Kesenian Daerah Istimewa Yogyakarta, Yogyakarta.
Supriyanto (Tari Klana Alus Sri Suwela Gaya Yogyakarta Perspektif Joged Mataram)

1981. "Ragam Tari Klasik Gaya Yogyakarta", dalam Fred Wibowo (ed), Mengenal Tari Klasik Gaya Yogyakarta. Dewan Kesenian Daerah Istimewa Yogyakarta, Yogyakarta.

1981. "Penjelasan Tentang Pathokan Baku dan Penyesuaian Diri", dalam Fred Wibowo (ed), Mengenal Tari Klasik Gaya Yogyakarta. Dewan Kesenian Daerah Istimewa Yogyakarta, Yogyakarta.

Wibowo, Fred. 2002. Tari Klasik Gaya Yogyakarta. Yayasan Bentang, Yogyakarta. 


\title{
PELAJARAN TARI : IMAGE DAN KONTRIBUSINYA TERHADAP PEMBENTUKAN KARAKTER ANAK
}

\author{
Oleh : Kuswarsantyo \\ Dosen Juruan Pendidikan Seni Tari Fakultas Bahasa dan Seni, Universitas Negeri Yogyakarta
}

Tari adalah salah satu cabang seni yang dalam ungkapannya menggunakan bahasa gerak tubuh. Untuk mencapai kualitas kepenarian yang bagus, seorang penari dituntut penguasaan aspek wiraga, wirama dan wirasa. Namun ternyata tidak hanya cukup penguasaan tiga aspek tersebut agar pemahaman tari secara utuh dipahami. Aspek di luar teknis sebenarnya lebih banyak manfaat yang bisa kita peroleh jika kita mempelajari tari secara kontekstual.

Permasalahan seputar pelajaran tari di sekolah umum (baca : SD, SMP, dan SMA) sebenarnya berkutat pada masalah image orang terhadap pelajaran tari yang dipandang sebelah mata. Pertanyaan yang pantas kita ajukan kepada para pelaku dan pendidik seni tari adalah : mampukah kita merubah image tari dari pemahaman tekstual menjadi kontekstual?

Manfaat yang dapat kita peroleh dari pemahaman secara konteksualitas tentang tari sebenarnya akan memberikan kontribusi yang signifikas terhadap pembetukan karakter siswa yang mempelajari. Kedalaman isi dan makna di balik pelajaran tari inilah yang selama ini belum banyak dikupas pendidik seni tari di sekolah umum. Dengan pemahaman kontekstualitas itu maka anggapan tari sebagai pelajaran praktik ansich akan terkikis. Tari adalah pelajaran yang memiliki kompleksitas permasalahan terkait dengan masalah sosial, budaya, antropologi, politik hingga permasalahan global. Untuk itulah belajar tari yang benar adalah belajar secara kontekstual dengan mempertimbangkan apa yang ada dalam tari itu secara utuh, sehingga kita tidak hanya terpancang pada aspek teknik dalam olah wiraga saja. Pemahaman nilai-nilai filosofi joged mataram menjadi penting artinya, karena akan memberikan manfaat untuk pembentukan karakter bagi anak yang mempelajarinya Konsep sawiji, greget, sengguh dan ora mingkuh dapat diterapkan dalam kehidupan seharihari, karena prinsip tersebut merupakan dasar untuk melaksanakan kehidupan yang oleh Suryobrongto disebut dengan way of life.

\section{PENGANTAR}

Belum banyaknya masyarakat yang paham tentang nilai-nilai di balik pelajaran tari adalah salah satu penyebab mengapa pelajaran tari di sekolah umum (baca: SD, SMP, dan SMA) masih dipandang sebelah mata. Hal ini ditambah dengan persepsi mayoritas guru di sekolah terhadap seni tari masih sebatas pada pelajaran praktik yang hanya bermodalkan sampur dan kaset. Dampaknya, pelajaran tari dianggap tidak penting dan hanya dijadikan pelajaran ekstrakurikuler yang sifatnya tidak wajib (pilihan). Sungguh memprihatinkan jika kita melihat perlakuan tersebut di sekolah umum yang mendiskreditkan pelajaran tari.

Permasalahan ini telah berlangsung sejak lama, dan hingga kini masih belum muncul adanya tanda-tanda pelajaran tari di sekolah umum mendapatkan tempat yang proporsional. Pelajaran tari di sekolah umum yang diberikan sejak Sekolah Dasar hingga Sekolah Menengah Atas, masih berstatus sebagai pelajaran ekstra di sebagian besar sekolah. Kalaupun ada sekolah yang menerapkan pelajaran tari sebagai bagian pelajaran wajib tempuh, ini karena kepala sekolah yang menjabat sangat peduli dengan seni. Ironisnya belum banyak kepala sekolah di wilayah kota Yogyakarta atau DIY umumnya yang peduli dengan pelajaran seni tari.

Kenyataan ini menjadi keprihatinan kita bersama, khususnya guru-guru tari yang mayoitas telah lulus sertifikasi. Dengan persyaratan administratif yang mewajibkan seorang guru harus mampu mengajar tiap minggu minimal 24 jam, menjadikan guru tari kalang kabut. Kebijakan sekolah untuk memanfaatkan guru tari mengajar bidang lain adalah alternatif yang "dipaksakan", karena 
tidak sesuai dengan kompetensi keahliannya. Bagaimana dengan hasil yang dicapai oleh guru tari ketika harus mengajar bahasa Jawa atau bahasa Indonesia? Ini tentu saja akan menimbulkan masalah baru di dunia pendidikan kita. Namun itu adalah urusan bidang kurikulum untuk bisa mengatasinya.

Tugas berat yang harus mampu dibuktikan oleh guru tari di sekolah yang mayoritas ditempati alumni UNY dan ISI, adalah bagaimana meyakinkan minimal kepada sesama guru di sekolah itu, Kepala Sekolah, dan pada masyarakat umumnya tentang hakikat pelajaran seni tari. Ada beberapa hal yang terlupakan di mata guru tari di sekolah yang hingga saat ini masih "malas" untuk mengembangkan kemampuan dirinya di luar masalah psikomotorik. Dua aspek lain yakni kognitif dan afektif belum optimal diterapkan. Apalagi setelah menerima sertifikasi, bukan untuk kepentingan peningkatan kemampuan profesional, tetapi justru untuk merubah gaya hidup yang tidak ada relevansinya dengan kompetensi bidang keilmuannya. Ini adalah satu ironi yang sebenarnya bisa menjadi bumerang bagi guru yang akan memunculkan image buruk terhadap pelajaran tari ke depan. Permasalahan ini tentu saja berpulang pada nurani guru tari yang selama ini sudah mengikrarkan dirinya menjadi pendidik professional.

Bagaimana langkah ke depan untuk dapat memaksimalkan pelajaran tari di sekolah, sehingga tidak lagi dianggap sebelah mata sebagai pelajaran praktik ansich. Mengingat pentingnya misi di balik pelajaran tari, sebenarnya guru-guru tari masih harus banyak belajar tentang nilai-nilai filofosi dan edukasi yang terkait dengan karya tari yang diajarkan. Pemahaman guru tari terhadap makna di balik pelajaran tari ini yang perlu digali sebagai upaya untuk meyakinkan pada steakholder minimal di tingkat sekolah, sesama guru, dan masyarakat secara umum. Upaya yang harus dilakukan guru-guru tari untuk memberikan penyadaran kepada masyarakat bahwa pelajaran tari dapat dijadikan media untuk membentuk jatidiri menuju insan yang berkarakter, adalah satu tuntutan yang mendesak segera ditemukan solusinya.

\section{SENI TARI}

Berkaitan dengan upaya untuk menjadikan tari sebagai media untuk membentuk jatidiri, perlu kiranya kita paham terlebih dulu dengan apa yang dimaksud tari dalam konteks ini. Ada tiga kategori tari yang dikenal masyarakat berdasarkan latar belakang penciptaanya. Ada tiga kategori yang bisa disebutkan di sini yakni, tari klasik yang berbasis di kraton. Kedua tari kerakyatan, adalah tari yang berkembang di wilayah pedesaan. Dan ketiga, tari modern kontemporer yang menjadi konsumsi masyarakat di perkotaan dengan gaya atau trend kekinian. Dalam konteks pembahasan ini kita akan mengambil seni tari klasik yang berbasis di kraton. Mengapa tari klasik yang kita jadikan rujukan? Ini terkait dengan nilainilai yang ada di dalam tari klasik yang secara universal sebenarnya memiliki muatan edukatif yang sangat luar biasa dan dapat diterapkan untuk berbagai kepentingan. Tidak bermaksud mengenyampingkan dua kategori tari lain, tari klasik dipilih karena memiliki kedekatan dengan prinsip dan pola hidup manusia yang oleh Suryobrongto disebut sebagai way of life (Suryobrongto, $1981: 23$ )

Tari Klasik Gaya Yogyakarta sering juga disebut dengan joged méataram. Hal ini karena latar belakang historis, di mana penciptaan tari klasik gaya Yogyakarta lebih dekat dengan Kraton sebagai pusat Kebudayaan yang ketika itu merupakan patronase seni istana. Tari klasik gaya Yogyakarta merupakan tarian yang bersifat abstrak dan simbolik, yang mengandung maksud tertentu. Tari klasik merupakan permainan garis atau lijnenspel yang sekilas jika dilihat tidak ada artinya, akan tetapi setelah di stilering ternyata terdapat simbolisasi dari karakter yang dikandung dalam ragam-ragam tari. Kompleksitas ragam dan unsur yang ada dalam tari klasik gaya Yogyakarta itu memberikan daya tarik bagi orang yang ingin belajar tari secara holistik.

Pemahaman tari klasik secara utuh belum banyak diketahui masyarakat, termasuk sebagian guru tari yang baru belajar pada tataran teknik saja. Namun kedalaman nilainilai filosofi yang ada di balik tari klasik gaya Yogyakarta, belum banyak orang paham. Ada beberapa hal yang penting dipahami secara 
keilmuan tentang tari klasik gaya Yogyakarta. Secara teknik tari gaya Yogyakarta memiliki aturan baku yang harus dipenuhi seperti wiraga, wirama, dan wirasa. Sedangkan untuk pemaknaan dari sudut pandang semiotik, tari memiliki beberapa simbol yang jika dikaitkan dengan nilai-nilai kehidupan akan menjadi lebih bermakna seperti tersirat dalam gerak pucang kanginan, ngenceng encot, lénggot raga, dan sebagainya.

Dari makna di balik tari klasik gaya Yogyakarta ini, sebenarnya secara fungsional tari gaya Yogyakata memiliki fungsi dan tujuan sebagai media untuk mengembangkan sikap dan kemampuan agar siswa mampu berkreasi dan peka dalam berkesenian. Oleh karenanya, secara rasional pelajaran pendidikan seni di sekolah didasarkan pada hal-hal sebagai berikut :

1. Pendidikan seni memiliki sifat multilingual, multidimensional, dan multikultural

2. Pendidikan seni memiliki peranan dalam pembentukan pribadi siswa yang harmonis dalam logika, rasa estetis dan artistiknya serta etikanya dengan memperhatikan kebutuhan dan perkembangan anak untuk mencapai kecerdasan (EQ), kecerdasan intelektual (IQ), kecerdasan adversitas (AQ), dan kreativitas (CQ), serta kecerdasan spiritual dan moral.

3. Pendidikan seni memiliki peranan dalam pengembangan kreativitas, kepekaan rasa, dan inderawi serta terampil dalam berkesenian melalui pendekatan belajar dengan, belajar melalui seni, dan belajar tentang seni (Depdiknas, 2001 :7)

\section{Konsep Nilai dalam Tari Klasik}

Nilai adalah suatu penghargaan atau kualitas terhadap sesuatu hal yang dapat menjadi dasar penentu tingkah laku seseorang. Sesuatu itu dianggap bernilai bagi seseorang karena sesuatu itu menyenangkan (pleasant), memuaskan (satisfying), menarik (interest), berguna (useful), menguntungkan (profitable) atau merupakan satu keyakinan (bilief) (Daroeso, 1988 : 20). Pendapat lain dikemukakan Mardiatmaja (1986 ; 54), nilai menunjuk satu sikap orang terhadap sesuatu hal yang baik. Ada kaitan yang erat antara yang bernilai dengan yang baik. Nilai pada dasarnya berhubungan dengan kebaikan yang terdapat pada inti sesuatu hal. Dengan demikian nilai itu merupakan kadar relasi positif antara sesuatu hal dengan orang tertentu. Beberapa nilai itu antara lain nilai praktis, nilai sosial, nilai religius, nilai susila atau norma, nilai kultural, nilai estetis, dan nilai yang bersifat konsepsional. Nilai dapat saling berkaitan membentuk suatu sistem dan antara satu dengan lain koheren serta mempengaruhi segi kehidupan manusia.

\section{Terwujudnya Jatidiri Melalui Pendidikan Tari}

Konsepsi Ki Hadjar Dewantara tentang kebudayaan melatarbelakangi konsepsinya di bidang pendidikan, yang antara lain mendefinisikan pendidikan sebagai berikut: "Pendidikan adalah usaha kebudayaan yang bermaksud memberi bimbingan dalam hidup tumbuhnya jiwa raga anak, agar dalam garis kodrat pribadinya serta pengaruh lingkungannya mereka memperoleh kemajuan lahir-batin menuju kearah adab kemanusiaan" (Ki Hadjar Dewantara I, 2004, 342). Lebih lanjut Ki Hajar Dewantara mengemukakan nilai-nilai kehidupan yang berbunyi "Ing Ngarso Sung Tulodo, Ing Madya Mangun Karso, Tut Wuri Handayani". Apa yang terkandung dalam nilai-nilai tersebut adalah keteladanan, berkarya, dan dukungan. Dengan demikian, nilai-nilai universal ini berlaku di mana pun dan bagi siapapun, tidak dibatasi oleh Barat dan Timur. Instruksi Presiden (Inpres) Republik Indonesia No. 1 Tahun 2010 tentang Percepatan Pelaksanaan Prioritas Pembangunan Nasional, berisi penyempurnaan kurikulum dan metode pembelajaran aktif yang didasarkan pada nilai-nilai budaya bangsa. Perubahan kurikulum di Perguruan Tinggi dan di Sekolah harus memperhatikan instruksi presiden ini. Bagaimana memasukan nilai-nilai dalam kurikulum atau pada pembelajarannya. Ini adalah kesempatan para guru kesenian di sekolah untuk menerapkan sistem pembelajaran secara kontekstual.

Berkaitan dengan nilai-nilai kehidupan dalam belajar seni, Ki Hajar Dewantara (1937 : 173) mengatakan bahwa: 
pengajaran gendhing itu tidak saja untuk memperoleh pengetahuan dan kepandaian hal gendhing, namun perlu juga bagi tumbuhnya rasa kebatinan, karena selalu menuntun ke arah rasa kewiramaan (perasaan ritmis)... rasa keindahan (perasaan estetis)...rasa kesusilaan (perasaan etis) (p. 173).

Dalam pandangan Ki Hajar Dewantara rasa kebatinan ini dapat diperumpamakan para pemimpin agama serta gereja yang menggunakan musik untuk membuka rasa keagamaan dan juga sebagai pengasah budi (pembentukan watak). Selain itu, Dewantara menjelaskan bahwa tari dapat mengajarkan pangkal kesopanan dan keadaban (moral), serta keteraturan. Dengan kata lain, musik dan tari sangat berkaitan dengan keteraturan ritme atau wirama yang akan berdampak pada suatu keteraturan dan ketertiban dalam kehidupan, perasaan senang, dan bahagia. Dewantara juga berpendapat bahwa pengajaran gendhing (musik) atau seni adalah suatu upaya penanaman rasa bangga akan kekayaan budaya bangsa yang indah dan luhur. Pembelajaran nilai yang dikemukakan oleh Dewantara tersebut merupakan dampak atau manfaat belajar seni, nilai-nilai sendiri yang tidak secara langsung direncanakan untuk diajarkan.

Juju Masunah (2011 : 31) mencontohkan pendekatan pembelajaran nilai-nilai yang sekaligus belajar seni pada mata kuliah Tari Pendidikan. Dalam konteks ini, seni sebagai alatnya dan metode adalah cara mencapai tujuannya. Tari pendidikan bukanlah Tari Bentuk atau Tari Kreatif, akan tetapi sebuah pendekatan pembelajaran tari yang mengutamakan kreasi dan apresiasi. Seperti halnya standar kompetensi yang dirumuskan pada Kurikulum Tingkat Satuan Pendidikan (KTSP) tahun 2006, yaitu ekspresi dan apresiasi.

Dengan membawakan sebuah tarian, siswa telah dididik untuk berbuat sesuatu dengan penghayatan penuh. Kedua, terkait dengan apresiasi terhadap karya orang lain yang harus dilakukan untuk menanamkan sikap menghargai karya orang lain dapat diterapkan ketika materi sebuah tarian akan diajarkan kepada siswa.

\section{Mengimplementasikan Filososi Joged sebagai sarana membentuk karakter anak}

Untuk mengimplementasikan filosofi joged mataram sebagai sarana pembentuk karakter anak, terlebih dahulu diperlukan pemahaman mendasar terkait dengan perilaku dalam kehidupan sehari-hari. Perilaku tersebut adalah ; kejujuran, keberanian, hormat, tanggung jawab dan adil merupakan nilai-nilai dalam kehidupan yang harus dimiliki oleh setiap manusia. Dengan kata lain, pendidikan karakter identik dengan pendidikan nilai-nilai yang telah berlangsung setiap hari.

Black seperti dikutip Masunah (2005:31) berpendapat bahwa pendidikan karakter berisi tiga elemen yaitu:

\section{A common core of shared or universal values}

2. The belief that there are rational, objectively valid, universally accepted qualities to which people of all nations, creeds, races, socio-economic statuses, and ethnicity subscribe

3. The belief that traits (qualities) transcend political persuasions as well as religious and ethnic differences.

Tiga elemen di atas menekankan pada nilai-nilai universal dan kepercayaan terhadap keragaman dan keberbedaan. Lebih jauh diungkapkan bahwa untuk memasukkan pendidikan karakter ke sekolah, kewajiban pertama sekolah adalah mengidentifikasi nilai-nilai universal yang akan menjadi fokus pada program dan membuat sebuah komitmen untuk mengajarkan nilai-nilai tersebut. Jika dikaitkan dengan nilai-nilai yang ada dalam tari semua aspek tersebut dapat menjadi rujukan. Misalnya keberanian ini akan berhubungan dengan rasa percaya diri ketika seorang akan menari. Kedua saling percaya ini identik dengan sengguh yang merupakan bagian inti dari prinsip joged mataram.

Selanjutnya untuk menjabarkan bagaimana penerapan nilai-nilai filosofis joged mataram sebagai media untuk membentuk karakter anak dapat diawali dari pemahaman non teknis ketika orang sedang atau akan belajar menari. Dari sisi inilah nilainilai mendasar dari sebuah proses untuk 
membentuk budi pekerti itu mulai dapat disisipkan, termasuk cara penyampaian yang sesuai dengan karakteristik materi tari yang akan disampaikan. Proses berjalan menuju ke tempat pertunjukan, tata cara naik ke atas pentas, dan bagaimana bersikap terhadap guru yang sedang mengajar, adalah bagian dari proses pembentukan karakter sebelum memasuki materi tari yang diajarkan. Dari materi tari yang diajarkanpun dapat dijadikan media untuk membentuk perilaku siswa, ketika materi itu diberikan deskripsi, makna simbolik, serta nilai-nilai yang terkandung di dalamnya.

Semua aspek tersebut dapat diuraikan sebagai media untuk membentuk karakter anak, karena makna di balik sebuah tarian itu sendiri merupakan pendidikan batin yang tertuju pada kehalusan jiwa. Pendidikan batin yang dimaksud adalah kehalusan budi pekerti yang meliputi cara berikir, pandangn hidup dalam kaitannya dengan kepercayaan terhadap Tuhan Yang Maha Esa. Keteraturan melaksanakan kedisiplinan yang ketat pasti akan berakibat seseorang percaya diri. Dengan bekal percaya diri inilah, jika mampu diperdalam seseorang melalui pelajaran tari gaya Yogyakarta, maka orang akan lebih banyak mendapatkan ilmu dari nilai-nilai di balik tari itu dari pada sekedar teknik menari yang benar.

Tahap berikut adalah menerapkan nilainilai filosofis joged mataram dalam membentuk karakter anak, dapat dijabarkan dari prinsip sawiji, greget, sengguh dan ora mingkuh yang secara lengkap dapat dilihat dalam tabel berikut ini.

\begin{tabular}{|c|c|c|c|c|}
\hline No & $\begin{array}{l}\text { Aspek Joged } \\
\text { Mataram }\end{array}$ & Deskripsi & Prinsip perilaku & $\begin{array}{l}\text { Keterkaitan dengan } \\
\text { karakter anak }\end{array}$ \\
\hline 1 & Sawiji & $\begin{array}{l}\text { Wujud untuk selalu } \\
\text { konsentrasi dalam } \\
\text { menghadapi segala } \\
\text { kegiatan }\end{array}$ & $\begin{array}{l}\text { Pemahaman, } \\
\text { konsentrasi, } \\
\text { kesungguhan, } \\
\text { ketekunan }\end{array}$ & $\begin{array}{l}\text { Orang dituntut untuk } \\
\text { konsentrasi penuh dalam } \\
\text { menghadapi segala hl } \\
\text { agar tidak melakukan } \\
\text { kesalahan. }\end{array}$ \\
\hline 2. & Greget & $\begin{array}{l}\text { Ungkapan dinamika dalam } \\
\text { kehidupan yang harus } \\
\text { dilalui manusia }\end{array}$ & $\begin{array}{l}\text { Kesungguhan, } \\
\text { kemauan, ketekunan }\end{array}$ & $\begin{array}{l}\text { Dinamika dalam } \\
\text { kehidupan harus menjadi } \\
\text { dasar untuk memahami } \\
\text { sesuatu }\end{array}$ \\
\hline 3. & Sengguh & $\begin{array}{l}\text { Kepercayaan diri manusia } \\
\text { dalam segala situasi anpa } \\
\text { harus menyongbongkan } \\
\text { diri }\end{array}$ & $\begin{array}{l}\text { Pemahaman, } \\
\text { kesungguhan, } \\
\text { ketekunan }\end{array}$ & $\begin{array}{l}\text { Sikap yang harus } \\
\text { dikedepankan oleh setiap } \\
\text { manusia dalam } \\
\text { menghadapi segala } \\
\text { situasi. Jangan cepat } \\
\text { puas sebelum apa yang } \\
\text { diperoleh itu jelas. } \\
\text { Jangan merasan bias } \\
\text { padahal tidak bias. } \\
\text { Jangan merasa lebih baik } \\
\text { dari pada teman lainnya }\end{array}$ \\
\hline 4. & Ora mingkuh & $\begin{array}{l}\text { Sikap pantang menyerah } \\
\text { untuk menggapai sebuah } \\
\text { cita cita }\end{array}$ & $\begin{array}{l}\text { Kemauan, } \\
\text { kesungguhan, } \\
\text { ketekunan }\end{array}$ & $\begin{array}{l}\text { Jangan menyerah } \\
\text { sebelum dicoba. } \\
\text { Mempelajari sesuatu } \\
\text { tentu akan menghadapi } \\
\text { cobaan }\end{array}$ \\
\hline
\end{tabular}

Dari tabel di atas memberikan keyakinan bahwa apa yang ada di dalam joged mataram, ternyata dapat diimplementasikan ke dalam kehidupan sehari hari sebagai media untuk menanamkan nilai-nilai edukatif, dalam rangka pembentukan budi pekerti anak. Dari hasil tersebut menunjukkan bahwa adanya keterkaitan yang signifikan yang mampu 
memberi keyakinan kita bahwa aspek filosofis joged mataram dapat diterapkan sebagai media pembentukan karakter anak.

Selain itu konsep filosofis joged mataram dapat dipahami sebagai dasar pendidikan yang penerapannya dapat digunakan untuk membentuk karakter anak. Hal tersebut terdapat di dalam konsep dasar yang tertuang dalam prinsip wirasa sebagai syarat belajar tari. Pengolahan rasa di sini lebih banyak menekankan pada aspek mental, di mana rasa percaya diri harus ditumbuhkembangkan sejak dini. Berolah rasa dalam konteks umum tidak hanya dipahami sebagai penguasaan atau penjiwaan karakter seperti ketika menari. Namun penguasaan rasa lebih memiliki makna yang universal dan dapat diterapkan dalam pendidikan karakter anak.

Sal Murgiyanto dalam bukunya Tradisi dan Inovasi: Beberapa Masalah Tari di Indonesia menjelaskan bahwa, pendidikan kesenian sangat penting sebagai pembentuk watak dan mental anak. Pendidikan dan pengalaman tari memberikan manfaat secara pribadi, sosial, kebudayaan, maupun kreativitas. Seni tari seperti cabang seni lainnya, memberikan kesenangan dan kegembiraan pada pelakunya. Gerakan tari dilakukan oleh seluruh tubuh secara intelektual, emosional, fisikal,tari merupakan sarana ideal untuk menumbuhkan kesadaran diri, perkembangan diri pada anak anak (Sal Murgiyanto, 2004 : 152). Merunut dari pendapat Murgiyanto, kini semakin jelas bahwa tari klasik gaya Yogyakarta dapat menjadi media untuk pendidikan anak.

\section{Kesimpulan}

Berdasarkan pada uraian tentang pemanfaatan nilai-nilai filosofis joged mataram sebagai media untuk membentuk karakter anak. Pendidikan karakter adalah pendidikan nilai-nilai. Untuk membangun bangsa yang berkarakter di tengah pluralitas budaya diperlukan guru yang memahami, mendalami, menghayati, dan mengimplementasikan nilai-nilai kehidupan, sehingga guru dapat mengajarkan nilai-nilai bersamaan dengan mengajarkan materi seni kepada siswa. Nilai dalam seni tidak hanya nilai estetis yang terlihat, tetapi nilai-nilai kehidupan yang tidak terlihat seperti hormat, peduli, tanggungjawab, cinta kasih, kejujuran, keadilan dan demokrasi.

Untuk itulah belajar tari yang benar adalah belajar secara kontekstual dengan mempertimbangkan apa yang ada dalam tari itu secara utuh, sehingga kita tidak hanya terpancang pada aspek aspek teknik praktis dalam olah wiraga saja. Pemahaman nilainilai filosofi joged mataram menjadi penting artinya, karena akan memberikan manfaat untuk pembentukan karakter bagi anak yang mempelajarinya Konsep sawiji, greget, sengguh dan ora mingkuh dapat diterapkan dalam kehidupan sehari-hari, karena prinsip tersebut merupakan dasar untuk melaksanakan kehidupan yang oleh Suryobrongto disebut dengan way of life.

Dengan pemahaman secara kontekstual itu maka image tentang pelajaran tari yang selama ini dipandang hanya sebagai pelajaran praktik akan terkikis. Kini sudah saatnya dibuktikan bahwa di balik pelajaran tari terdapat nilai-nilai yang dapat diterapkan dalam kehidupan sebagai sarana membentuk jatidiri. Oleh karena itu perlu dibangun sistem pendidikan yang dapat mengarahkan guru untuk mengajarkan nilai-nilai kehidupan melalui pelajaran tari.

\section{DAFTAR RUJUKAN}

Black, F.B., 2005. Democratic Practices as Manifested through Character Education. In Pearl, Art \& Pryor, Caroline R. Democratic. Eds. Practices in Education: Implication for Teacher Education. A Division of Rowman \& Litlefield Publishers, Inc., Maryland, U.S.A.

Daroeso, 1988. Konsep Nilai dalam Pendidikan. Kanisius, Yogyakarta.

Depdiknas, 2001, Kurikulum Berbasis Kompetensi Mata Pelajaran Pendidikan Seni SLTP. Depdiknas, Jakarta.

2002, Pendidikan Kontekstual (CTL). Depdiknas, Jakarta.

Kussudiardja, Bagong, 1992. Dari Klasik hingga Kontemporer. Padepokan Press, Yogyakarta. 
Majelis Luhur Persatuan Tamansiswa. 1994. Karya Ki Hadjar Dewantara. Percetakan Offset Tamansiswa, Jogjakarta

Masunah Juju, 2012. “Peranan Pendidikan Seni Dalam Konteks Pluralitas Budaya Untuk Membangun Bangsa Yang Berkarakter" dalam Kuswarsantyo, ed.al. Greget Joget Jogja. Bale Seni Condroradono, Yogyakarta.

2011. "Konsep dan Praktik Pendidikan Multikultural di Amerika Serikat dan Indonesia" dalam Jurnal Ilmu Pendidikan. pp. 298-306. Jilid 17, Nomor 4, Februari 2011.
, 2010. "Pendidikan Multikultural dan Demokrasi", dalam Narawati dan Masunah, J. Eds. Quo Vadis Seni Tradisional $V$ : Meningkatkan

Murgiyanto, Sal, 1993. Tradisi dan Inovasi : Beberapa Permasalahan Tari di Indonesia. Institut Kesenian Jakarta, Jakarta.

Suryobrongto, 1981. Mengenal Tari Klasik gaya Yogyakarta, Editor Fred Wibowo. Dinas Kebudayaan Propinsi DIY, Yogyakarta. 


\title{
SISTEM PEWARISAN PENARI ROL DALAM WAYANG ORANG PANGGUNG
}

\author{
Dr. Hersapandi,SST.,MS. \\ Jurusan Tari Fakultas Seni Pertunjukan ISI Yogyakarta \\ Email: hersapandi.17@gmail,com
}

\begin{abstract}
The system of inheritance in the puppet stage appears to face a popular issue on the values of professionalism that demands self-discipline and commitment to wrestle in total. Inheritance takes place in two categories, namely: the first category that the inheritance according to the direct lineage or a child of the dancer roller. The second category, the inheritance of acquired dancer roller which is not the biological parent, but as a senior where he played the puppet people. Although they were aware that the dancer roller is never created because it is considered as a replacement actor rivalry.

A top dancer is an individual who has a mastery of knowledge and the quality of the high technical skills, and be able to incarnate into a figure that was delivered. The top dancer transmission regeneration in the context of the puppet stage is a must propesional profession in building a public figure image as an iconic of audience appeal.
\end{abstract}

Keywords: top dancer, professional, icons appeal, inheritance

Sistem pewarisan dalam wayang orang panggung populer tampaknya dihadapkan suatu permasalahan tentang nilai-nilai profesionalisme yang menuntut adanya disiplin diri dan komitmen untuk menggeluti secara total. Pewarisan berlangsung dalam dua kategori, yaitu: kategori pertama bahwa pewarisan menurut garis keturunan langsung atau anak kandung penari rol. Kategori kedua, yaitu pewarisan yang didapatkan dari penari rol yang bukan orang tua kandung, tetapi sebagai seniornya di tempat ia bermain wayang orang. Meskipun disadari bahwa penari rol tidak pernah menciptakan aktor pengganti karena dianggap sebagai rivalitas.

Seorang penari rol adalah individu yang memiliki kualitas penguasan pengetahuan dan keterampilan teknik yang tinggi, serta mampu menjelma ke dalam tokoh yang dibawakan. Transmisi kaderisasi penari rol dalam konteks wayang orang panggung propesional adalah suatu keharusan profesi dalam membangun pencitraan figur publik sebagai ikon daya tarik penonton.

Kata kunci: penari rol, profesional, ikon daya tarik, pewarisan

\section{Latar Belakang Masalah}

Berbicara tentang sistem pewarisan manusia, maka pertanyaan pokok adalah apakah manusia memiliki sistem-tiruan berbasis mekanisme warisan yang berfungsi evolusi transmisi fenotipe perilaku andal dari generasi ke generasi. Untuk memiliki kekuatan evolusioner dari sistem warisan, mekanisme berbasis imititasi harus memenuhi berbagai tuntutan persyaratan. Mungkin kekayaan budaya manusia karena kemampuan meniru bawaan dan unik? Kualitas manusia meniru sama sekali tergantung dalam konteks sosial atau sesuai ' pedagogis alami'. Selektifitas tindakan mereka yang cenderung meniru, mereka muncul untuk menunjukkan apresiasi terhadap sifat disengaja model tindakan dan struktur kausal dari masalah yang itu diterapkan. (http://rstb.royalsocietypublishing.org/content/ 364/1528/2429.full). Sifat meniru bawaan dan unik pada manusia dalam konteks sosial adalah suatu mekanisme pembelajaran dengan menyerap berbagai informasi tentang pengetahuan dan keterampilan teknik yang 
pada gilirannya membentuk karakter pribadi individu. Ia sebagai individu yang memiliki intelejensi dan integritas kualitasnya ditentukan oleh seperangkat tata nilai dari potensi diri yang berproses dan dibesarkan oleh lingkungannya.

Fenomena penari rol sebagai agen adalah individu aktor yang memiliki kharisma yang dibangun dari profesionalisme kesenimanan yang sempurna, baik secara fisik atau lahir yang menyangkut kualitas keterampilan teknik maupun secara psikis atau batin yang menyangkut kualitas spiritualitas. Keseimbangan kualitas kepenarian penari rol adalah sosok seniman yang memiliki tingkat kemampuan pengetahuan dan keterampilan yang tinggi dengan dibekali ilmu kebatinan yang memadahi untuk membentengi diri untuk menghadapi medan pergolakan sosial seperti adanya pengaruh jahat yang bersifat gaib. Hal ini dilatarbelakangi fenomena penari rol tempo dulu yang cenderung mendapat persaingan yang tidak sehat melalui kekuatan gaib, sehingga yang bersangkut tiba-tiba tidak dapat menari dan berbicara di atas pentas (Kies Slamet, wawancara tanggal 19 Juli 2009). Dominasi otoritas dan kharisma penari rol sebagai agen mendorong para juragan wayang orang panggung populer berlombalomba mendapatkan mereka guna kepentingan bisnisnya. Oleh karena itu, maka dengan segala cara bahkan kurang terpuji juraganjuragan wayang orang itu merekrut penari rol melalui janji tawaran bayaran lebih tinggi dan mendapatkan fasilitas yang lebih baik. Persaingan tidak sehat ini merupakan hal yang biasa terjadi, dan bagi seniman gejala ini dimanfaatkan untuk memperbaiki kesejahteraan hidup keluarga dan sekaligus untuk mencari pengalaman baru berkesenian.

Dominasi otoritas penari rol wayang orang melekat dalam diri aktor, yaitu kualifikasi aktor yang memiliki kewenangan dalam menentukan kebijakan artistik, ukuran dan kualitas estetis untuk kepentingan perkembangan karya seni. Dominasi otoritas penari rol adalah kewenangannya dalam grup, bahkan manager dan sutradara pun tidak mutlak mempunyai kebijakan terhadap penari rol. Spiritnya dapat memotivasi grup dan penonton, sehingga tindakannya kalau tidak terkendali menjadi kendala kekompakan kelompok itu sendiri, yang memungkinkan grup itu dapat hancur karena arogansi penari rol (ahersapandi, 2011: 143). Dominasi otoritas ini tentu memiliki kekuatan yang melahirkan suatu kharisma karena ketokohannya. Menurut Weber, keberhasilan agen menjadi faktor penentu hal-hal yang ia kehendaki (Weber, 1946: 295). Suatu keberhasilan aktor merupakan dasar pembentukan kekuatan yang berujung pada kharisma dalam menjaga nilai-nilai profesionalisme berkesenian. Menurut Waters, variasi kekuatan itu mencakup: (1) daya tarik yang dimiliki aktor; (2) sejumlah distribusi kekuatan yang tersebar atau terpusat; (3) lingkup kekuatan yang dibatasi aktivitas khusus, dan (4) daerah kekuatan yang dibatasi oleh kelompok yang subordinatif (Waters, 1994: 242). Kekuatan aktor dalam tradisi pemain wayang orang atau seniman tradisi lain, tampaknya harus diimbangi dengan laku ritual sebagai upaya penangkal pengaruh jahat dari luar.

Laku ritual penari rol sebagai agen ialah tindakan praktis sosial yang terkait dengan kebutuhan spiritual aktor untuk mempertebal rasa percaya diri dalam menjaga kelangsungan hidup berkesenian. Di lingkungan seniman wayang orang, seorang pemain secara individual cenderung mengelola diri dengan memadukan kemampuan keterampilan teknik dengan kemampuan keterampilan spiritual, sehingga keseimbangan potensi diri itu diharapkan mampu menjaga profesionalisme. Penguasaan olah batin ini merupakan bagian dari strategi aktor dalam menjaga pencitraan diri, sehingga yang bersangkutan memancarkan aura yang mampu menggetarkan penonton. Di era Rusman, tampaknya laku ritual dibutuhkan oleh penari untuk menjaga keseimbangan lahir (fisik) dan batin (spiritual). Seperti dijelaskan oleh Slamet Wiyono (adik Rusman nomor 10 dari 11 bersaudara), bahwa Rusman belum begitu mantap dengan kemampuan keterampilan tekniknya, sehingga secara spiritual ia melakukan laku ritual di makam Balakan di Langenharjo Sukoharjo untuk mendapatkan pelarisan (Hresapandi, 2011: 179-180). Keterpaduan antara teknis dan spiritual adalah kesempurnaan seorang seniman wayang orang dalam menjual "adol kabisan", terutama dalam menjaga stabilitas berkesenian. Seperti diketahui, bahwa 
persaingan antar penari rol merupakan fenomena zamannya sebab ketika itu tidak jarang mereka mencelakakan seniman lain dengan cara menjatuhkan lewat kekuatan gaib. Misalnya, penari rol tiba-tiba tidak mampu bersuara ketika sedang berdialog atau nembang, dan penari rol secara mendadak tidak mampu menari di atas pentas yang berakibat fatal pada penampilannya (Ibid.)

Dalam sistem pewarisan penari rol wayang orang tampaknya berlaku sistem magang, yaitu proses transmisi secara longgar bagi penari yang dipandang memiliki kualifikasi kemampuan keterampilan teknik gerak dan vokal untuk memerankan tokoh tertentu dalam wayang. Sistem magang dalam wayang orang secara tradisi melakukan suatu metode pendidikan yang didasarkan pada aktivitas individu untuk melihat secara langsung suatu pertunjukan dan secara detail mencatat. Kemudian aktor itu menirukan apa yang dilakukan oleh penari senior dan menguasai semua perbendaharaan gerak, vokal, dan tembang. Tahap paripurna adalah aktivitas mengembangkan materi perbendaharaan gerak sesuai dengan membangun gaya pribadi aktor. Kesempurnaan penari rol ketika ia mampu menampilkan gaya pribadi yang dikembangkan berdasarkan pengalaman belajar pada seniornya. Pola pewarisan dalam sistem magang dipandang strategis dalam mentransfer seluruh kemampuan aktor, sehingga memungkinkan terjadinya kesinambungan regenerasi aktor. Substansi sistem pembeljaran ini sesungguhnya mirip dengan metode $3 \mathrm{~N}$ Ki Hadjar Dewantara, yaitu Niteni, Nirokake, dan Nambahi. Niteni adalah selalu memperhatikan sampai hal-hal detail, Nirokake adalah selalu mencontoh halhal yang dianggap bagus/hebat dsb, dan Nambahi yaitu menambah hal-hal yang dipandang bagus, sehingga menjadi the best. (http://husnimuarif.wordpress.com/tag/emaneman/). Belajar seni tradisi dan keterampilan kerajinan seperti batik, ukir, anyam dapat dilakukan dengan menggunakan metode $3 \mathrm{~N}$ atau 3 M yaitu Mengamati, Meniru, dan Mengembangkan yang digunakan dalam pembelajaran di Tamasiswa oleh Ki Hajar Dewantoro. Metode $3 \mathrm{~N}$ (http://eprints.uny.ac.id/3767/1/08Martono.pd f).
Sistem pewarisan sebenarnya tidak hanya terbatas pada pengetahuan dan keterampilan teknik yang tinggi serta kemampuan membalikkan karakter tokoh yang dibwakan, tetapi juga pemakaian nama tokoh senior yang mewarisi. Misalnya, pemakaian nama Harjowibaksa merupakan bentuk nunggaksemi ${ }^{l}$ dari nama penari rol pemeran tokoh Gathutkaca wayang orang Sriwedari yaitu Harjowugu Wibaksa. Hal yang menarik dari nunggaksemi ini adalah suatu bentuk transmisi kader penari senior kepada penari junior sebagai aktualisasi nilai-nilai kesenimanan dan pencitraan aktor. Sayangnya, dalam wayang orang Sriwedari tradisi nunggaksemi hanya berjalan sekali dalam rentang waktu 101 tahun, sehingga ketiadaan transmisi ini berdampak pada menurunnya kualitas aktor, terutama penari rol sebagai daya tarik dan ikon penonton. Hal ini disebabkan oleh dua sebab, yaitu (1) kurang harmonisnya hubungan dengan institusi keraton Kasunanan Surakarta sejalan dengan kehilangan pamornya, dan (2) sifat dominasi otoritas Rusman sebagai penari rol yang mempertahan reputasinya sampai akhir hayatnya (Hersapandi, 2011: 5).

Ironisnya, dalam wayang orang penari rol tidak menciptakan aktor pengganti karena dianggap sebagai rivalitas. Artinya, secara sistematik ia tidak mentrasmisikan keahliannya secara langsung kepada yuniornya, sehingga ia mampu mempertahankan superioritasnya sebagai penari rol tak tertandingi di zamannya. Oleh karena itu, intensitas proses pewarisan dalam wayang orang sangat tergantung dari sikap proaktif individu aktor, intelejensi dan integritas aktor sebagai pewaris aktif dalam lingkungan aktor. Di samping itu juga, kualitas pewarisan ditentukan oleh bekal pengetahuan dan keterampilan teknik aktor. Misalnya, Rusman belajar menari dari guru dan empu tari Kadipaten Mangkunegaran dan Kasunanan Surakarta, antara lain guru Darmo yang mengawali nelajar menari Rusman, Demang Poncosewaka empu tari dari Pura Mangkunegara (Rusini, 2003: 45-46). Pengalaman berkesenian menjadi faktor

${ }^{1}$ Dalam tradisi Jawa, pengertian nunggaksemi biasanya dikenakan pada orang yang menggunakan nama ayahnya atau nama tokoh senior yang memiliki nilai karismatik, (lihat Rustopo, 2008: 292). 
penentu keberhasilan aktor dalam proses pewarisan tradisi yang berdampak popularitas sebagai figur publik yang menjadi daya tarik dan ikon wayang orang.

Dalam berbagai kasus, bahwa munculnya penari rol baru datangnya terkadang tidak terduga-duga. Ia menggantikan seniornya ketika berhalangan hadir karena berbagai alasan teknis seperti sakit, karena suatu tugas pribadi, atau alasan lain yang menyebabkan yang bersangkutan absen. Ketidakhadiran seniornya ini tentu menjadi kesempatan yang harus dimanfaatkan untuk membuktikan kualitas kesenimannya. Pembuktian kualitas kepenarian ini merupakan kondisi objetif yang memungkinkan dirinya benar-benar membuat detak kagum penonton. Ukuran keberhasilan penari rol pengganti adalah apabila ia mampu merepresentasikan dirinya sebanding dengan penari rol yang digantikan. Bahkan jika memungkinkan, ia dapat mengungguli aktor seniornya dalam membawakan tokoh yang dibawakan. Kesan yang ditangkap adalah kualitas penampilan, baik aspek kualiats keterampilan teknik gerak dan vokal maupun penguasaan dramatikalnya.

\section{Sistem Pewarisan Penari Rol Wayang Orang}

Tiadanya penari rol yang handal dalam wayang orang panggung populer masa kini sebenarnya dilatarbelakangi oleh lemahnya sistem pewarisan penari rol. Hal ini disebabkan oleh dominasi otoritas penari rol yang tidak menciptakan aktor pengganti karena dianggap sebagai rivalitasnya. Menariknya, penari rol baru muncul secara mendadak karena kekosongan atau ketidakhadiran penari rol. Sebagai pemeran pengganti ada dua kemungkinan yang terjadi, yaitu: kemungkinan ia berhasil dan bahkan kualitasnya melebihi aktor yang digantikannya, atau kemungkinan ia gagal karena tidak cukup memiliki kualitas kesenimanan yang mampu menciptakan daya tarik penonton. Misalnya, kasus munculnya Rusman sebagai penari rol yang menjadi idola penggemar wayang orang Sriwedari, sebenarnya merupakan faktor kebetulan yang ketika itu ada kesempatan untuk main menggantikan tokoh Gathutkaca yang diperankan Harjowugu Wibaksa. Seperti dikemukakan oleh Soemardjo Hardjoprasonto, bahwa penampilan Rusman ketika menggantikan Wugu Harjawibaksa memiliki kualitas yang mirif, terutama 'gregetnya', namun Rusman mampu menciptakan dirinya sebagai Rusman, bukan Harjowugu. Akhirnya, penampilannya sudah Gathutkaca Rusman yang utuh yang sama sekali berbeda dengan Gathutkaca Harjowugu (Hardjoprasonto, 1997: 132). Kualitas kepenarian yang luar biasa ini, merupakan pencitraan aktor yang diidolakan para penggemarnya, bahkan mampu menjadi idola Presiden Soekarno dan penari rol legendaris di zamannya.

Fenomena pewarisan penari rol secara garis besar dipilahkan menjadi dua, yaitu (1) penari rol yang berasal dari keturunan atau anak penari rol, (2) penari rol yang bukan berasal dari keturunan atau anak penari rol, tetapi memiliki kelebihan secara pengetahuan dan keterampilan teknik yang tinggi, sehingga ia layak memiliki kualifikasi penari rol. Pewarisan penari rol merupakan faktor determinan yang menjadi dasar pembentukan kualitas aktor dalam rangka menjaga pencitraan dan reputasi pertunjukan. Bahkan, kebijakan manajemen wayang orang panggung populer tempo dulu senantiasa bergantung pada penampilan penari rol. Menurutnya, tanpa penari rol, maka pertunjukan tidak laku dijual. Artinya, superior penari rol menjadi kata kunci keberhasilan sebuah pertunjukan profesional. Oleh karena itu, pewarisan penari rol dipandang penting untuk mempertahankan reputasi sebuah grup kesenian komersial. Di Jepang salah satu negara modern yang masih menghargai seni tradisinya, tampaknya memiliki tradisi sistem pewarisan pemain bintangnya sebagai bentuk pencitraan aktor. Misalnya, teater Kabuki yang masih mempertahankan tradisi transmisi pemain bintang secara ketat, yakni (1) Ia harus keturunan pemain bintang, (2) Ia menjadi menantu anak pemain bintang, dan (3) Ia diangkat menjadi anak angkat pemain bintang (Himiko, wawancara pada tanggal 30 Januari 2010). Tradisi transmisi dari tokoh tua ke tokoh muda di lingkungan teater Kabuki merupakan strategi untuk menjaga spirit berkesenian terkait upaya pencitraan kesenian 
itu dengan penonton sebagai basis sosial. Bentuk pencitraan itu dicerminkan oleh sikap maestro Kabuki dalam menciptakan pola tari dan akting yang khas, yang kemudian diwariskan kepada keturunan-keturunannya (Tati Narawati dan Soedarsono, 2005: 237). Penciptaan tradisi pewarisan ini dipandang penting dan terbukti menjadi kunci sukses pertunjukan teater Kabuki dan dicintai masyarakat modern Jepang mutakhir.

\section{Penari Rol yang berasal dari Keturunan atau Anak Penari Rol}

Fenomena anak tobong merupakan peristiwa proses kesenimanan yang didapat oleh para pemain wayang orang sebagai keturunan atau anak penari rol. Dominasi otoritas penari rol melekat dalam diri aktor yang diposisikan sebagai pemimpin budaya. Dominasi otoritas dan kharisma yang melekat pada individu aktor adalah mencerminan parameter keunggulan kompetetif agen sebagai seniman di papan atas. Predikat anak penari rol tentu memiliki kesempatan lebih untuk menyerap pengetahuan dan keterampilan teknik dari orang tuanya. Sejak usia dini, anak, dewasa, dan orang tua dari aspek waktu senantiasa dapat belajar langsung dengan orang tuanya. Mulai bangun tidur, pagi, siang dan malam hari ia mendapat kesempatan untuk berinteraksi dengan orang tuanya. Proses perjalanan berkesenian ini membentuk karakter aktor sebagai individu yang mampu menjadikan dirinya sebagai figur publik yang populer di zamannya. Pembentukan karakter penari rol sangat tergantung dari kualitas individu, intejensi, dan integritas agen sebagai penari yang memiliki keunggulan kompetetif. Bahkan, pada tingkat tertentu ia harus mendapatkan pulung melalui laku spiritual yang berat. Oleh karena itu, menuju predikat penari rol bukan permasalahan yang mudah bagi aktor, tetapi membutuhkan kerja keras lahir dan batin untuk mencapai impiannya sebagai penari kesayangan penonton. Dominasi otoritas dan kharisma penari rol dapat berkurang atau bahkan hilang apabila individu yang memilikinya berbuat kesalahan-kesalahan yang merugikan masyarakat atau mental individu yang mendukungnya tidak kuat (Soekanto, 1986: 258).

Koesseno Brojo Kuncoro lahir 4 Juli 1952 di Semarang adalah anak pertama dari seniman kondang wayang orang Ngesthi Pandawa Semarang, yaitu Koesni. Koesni adalah penari rol dan sutradara terkenal wayang orang Ngesthi Pandawa Semarang. Ia adalah anak tobong yang setiap hari bergelut dengan seniman wayang orang, sehingga secara alami ia belajar dari lingkungan budayanya, baik menyangkut pengetahuan tentang dunia pewayangan maupun keterampilan teknik gerak dan suara. Sebagai anak tobong ia demikian dekat dengan dunia pemanggungan wayang orang. Koesseno Brojo Kuncoro dikenal penari rol tahun 1970an yang memiliki kualifikasi keaktoran baik dan mumpuni. Ia lahir dan dibesarkan di lingkungan wayang orang Ngesthi Pandawa Semarang ketika masa pertumbuhannya di era kebesaran nama Rusman Harjowibaksa sebagai penari Gathutkaca. Kualitas keaktorannya dibentuk oleh spirit berkesenian di lingkungan seniman wayang orang Ngesthi Pandawa Semarang, sehingga tidak mengherankan apabila ia merupakan pewaris aktif dari struktur dominasi otoritas dan kharisma Koesni. Duet permainan di atas panggung selalu menjadi tontonan yang menarik dan ditunggu-tunggu oleh para penggemarnya. Oleh karena itu, tidak mengherankan apabila BUMN Pertamina Unit IV Semarang secara rutin memborong kursi pertunjukan wayang orang Ngesthi Pandawa dengan catatan harus melibatkan pemain favoritnya, yaitu Koesni dan Koesseno. Misalnya untuk lakon "Kikis Tunggarana", pemeran tokoh Boma harus Koesni dan tokoh Gathutkaca dimainkan Koeseno. Apabila kedua penari rol itu tidak main, biasanya pentas dibatalkan dengan diganti hari lain asalnya kedua pemain itu tampil sebagai pemainnya (Hersapandi, dkk, 1998: 92).

Koeseno sebagai pewaris aktif struktur dominasi otoritas dan kharisma penari rol Koesni adalah pengagum Rusman sebagai seniman besar wayang orang Sriwedari. Ekspresi kekaguman itu ia buktikan ketika menjadi juara I Gathutkaca mirip Rusman dalam lomba tari tahun 1972 di mana Rusman sebagai salah satu anggota Dewan Juri (Hersapandi, 2011: 254) Hal ini menunjukkan 
bahwa Koesseno memiliki kualifikasi kepenarian yang baik dengan kualitas gerak di atas rata-rata peserta lomba. Pengakuan kualitas kepenarian itu dibuktikan ketika ia main bareng tiga kali dengan Rusman pada tahun 1980-an sebagai pemeran tokoh Gathutkaca asli dan Rusman pemeran tokoh Gathutkaca palsu dalam lakon yang menghadirkan dua peran tokoh Gathutkaca. Baginya, bermain bersama Rusman adalah kebanggaan tersendiri seorang seniman wayang orang dalam menjaga nilai-nilai profesionalisme. Untuk menjadi penari yang baik dibutuhkan sikap profesional dengan penguasaan pengetahuan dan keterampilan seni yang tinggi. Ia harus menjaga ketubuhannya dengan terus berlatih dan meningkatkan kualitas keaktorannya. Di samping itu, ia harus mampu menciptakan kreativitas yang membuat penonton terkesima dengan atraksinya di atas pentas. Dengan potensi diri diharapkan mampu mengembangkan kualitas gaya pribadi sebagai modal untuk membangun pencitraan sebagai aktor, bukan meniru orang lain, bahkan aktor idolanya. Kesadaran ini merupakan sikap proaktif untuk mengembangkan potensi diri agar menjadi idola penonton.

Koordinasi tata urutan gerak dengan teknik mengolah suara ketika berdialog dan bertembang serta penghayatan karakter tokoh yang dibawakan merupakan kekuatan Rusman, sehingga ia mampu mengeluarkan suara secara keras dan lantang di ruangan yang luas dengan kualitas suara yang mantab dan indah tanpa terkesan ngoyo (dipaksakan). Elaborasi teknik gerak dan teknik suara yang sempurna dan didukung pemahaman tentang struktur gending iringannya menjadi kekuatan tersendiri bagi keaktoran Rusman. Di sini Koesseno mencoba mendalami karakter tokoh Gathutkaca yang ditampilkan Rusman, sehingga kemampuan mengadaptasi ketubuhan dan keaktoran Rusman membawa konsekuensi logis terpilihnya ia menjadi pemeran tokoh Gathutkaca di mana Rusman juga sebagai patner bermain. Hal ini menunjukkan bahwa Koesseno memiliki kualitas keaktoran yang mampu mengimbangi keaktoran Rusman dalam membawakan peran Gathutkaca. Ia menyadari untuk dapat memahami gaya pribadi Rusman sebagai penari ulung dalam memerankan tokoh
Gathutkaca, bukanlah suatu pekerjaan yang mudah, namun dibutuhkan kontinuitas berkesenian dengan memerankan tokoh Gathutkaca secara terus-menerus dengan dilambari laku spiritual yang mendalam dan kepasrahan dalam sebuah pengabdian pada profesinya.

Disiplin berkesenian ia terapkan ketika menjadi sutradara di wayang orang Ngesthi Pandawa mewarisi ayahnya, Koesni. Penguasaan pengetahuan dan keterampilan teknik gerak atau suara yang bagus dan mantab tampaknya membawa Koeseno sebagai aktor yang mampu menciptakan kreativitas dan inovasi dalam upaya menjawab tantangan jaman. Oleh karena itu, ia tidak banyak menemui hambatan yang berarti ketika menciptakan koreografi wayang orang garap baru. Bahkan sebagai seniman muda wayang orang Ngesthi Pandawa, ia mendirikan komunitas generasi muda wayang orang Ngesthi Pandawa. Berdirinya komunitas generasi muda Ngesthi Pandawa ini dilatarbelakangi oleh keprihatinan menurunnya minat dan kualitas pemain muda sebagai dampak perubahan gaya hidup masyarakat pendukungnya sebagai akibat pengaruh kehidupan global.

Kehidupan kesenimanan Koesseno sebagai pemain wayang orang Ngesthi Pandawa memang tidak berjalan mulus, sebab ia harus mengorbankan profesinya untuk mengikuti kepindahan istrinya yang bekerja sebagai staf pengajar pada Akademi Seni Tari Indonesia Yogyakarta pada tahun 1976 (sekarang Jurusan Tari Fakultas Seni Pertunjukan Institut Seni Indonesia Yogyakarta). Meskipun demikian, ia masih wira-wiri (pulang-pergi) ke SemarangYogyakarta untuk pentas, bahkan tahun 1980an ia mendirikan komunitas generasi muda Ngesthi Pandawa. Wadah ini merupakan tempat menuangkan ide-ide baru menggarap format baru wayang orang, termasuk garap wayang orang dengan memanfaatkan multimedia. Namun sayangnya, peran Koesseno menjadi fasilitator kerja kreatif untuk generasi muda wayang orang Ngesthi Pandawa terhenti karena faktor jarak dan waktu serta kesibukan dalam keluarganya. 


\section{Penari Rol yang Bukan berasal dari Keturunan atau Anak Penari Rol}

\section{Pewarisan Rusman dari Harjowugu Wibaksa}

Dalam mendapatkan pewarisan atau penerusan dominasi otoritas dan kharisma penari rol yang berupa pengetahuan dan keterampilan seni, seorang pewaris atau penerus dapat menempuh melalui dua cara, yaitu (1) dengan cara berguru langsung kepada seorang penari rol, (2) secara tidak langsung dengan jalan menonton pertunjukan di mana penari rol itu sebagai bintangnya. Dalam proses pembelajaran itu seorang siswa didik harus mengikuti sistem pendidikan yang berlaku, seperti latihan menari, ujian dan pentas kenaikan peringkat sesuai dengan tingkat kesulitan materi ajar. Metode pembelajaran yang mengutamakan penyampaian dan transfer pengetahuan dan keterampilan seni melalui interaksi guru dengan murid secara individual dan intensif disebut "magang". Tidak jarang calon penari rol itu menetap tinggal di rumah dan mengabdi pada seorang guru atau empu seni. Aktor calon penari rol menjadi anggota keluarga baru dari sang guru, ikut mengambil pekerjaan seharihari, dan acap kali menjadi pembantu atau pengikut dari sang empu seni. Harapannya, aktor tidak saja terikat akan kebutuhan untuk mendapatkan pengetahuan dan keterampilan seni, lebih jauh lagi untuk meneruskan kehidupan suatu jenis kesenian. Untuk menyempurnakan pengetahuan dan keterampilan seni, seorang aktor biasanya memperkaya pengalaman berkesenian dengan rajin datang ke tempat-tempat pertunjukan untuk menonton penampilan para empu tari atau seniman-seniman yang sudah berpengalaman (lihat Dibia, 2004: 121-122).

Bagi Rusman, posisi penari rol merupakan hasil perjuangan kesenimanannya sebagai relasi kharismatik seorang penari rol Harjowugu Wibaksa yang populer sebagai penari Gathutkaca pada tahun 1930-an. Rusman demikian terinspirasi dengan ketokohan Harjowugu Wibaksa sebagai penari Gathutkaca yang ketika menjadi idola para penggemar wayang orang Sriwedari, terutama ce $\square$ ngkokce $\square n g k o k$ tembangannya. Tanda-tanda ketertarikan dengan wayang wong ternyata telah tampak ketika masih usia anak-anak. Oleh karena itu, tidak mengherankan jika pada masa kanakkanak Rusman bersama-sama teman sebayanya sering melihat pertunjukan wayang orang Sriwedari, terutama terkesan dengan penampilan Harjowugu Wibaksa ketika memainkan tokoh Gathutkaca. Bagi Rusman, melihat pertunjukan wayang orang Sriwedari adalah cara belajar pasif secara langsung kepada seniman idolanya. Bahkan bersama teman-teman sebayanya, suatu hari bermain wayang-wayangan di halaman sekolah dekat rumahnya. Saat mereka bermain itu, diketahui oleh seorang guru di sekolah itu, bahwa Rusman adalah salah seorang anak yang dianggapnya mempunyai bakat menari. Guru Darmo adalah orang pertama yang menjadi guru tari Rusman di masa kanakkanak (Rusini, 2003: 44), sebelum Rusman menjadi murid dari R.Ng. Wiryopradhata dan Demang Poncosewaka. Bakat seni yang dimiliki Rusman menempatkan ia sebagai seorang murid cerdas dan menonjol, sehingga dalam berbagai kesempatan pentas ia ditunjuk sebagai pemeran tokoh kunci yang membuat detik kagum penonton.

Kekaguman pada sang tokoh idola itu mendorong Rusman untuk mencoba mendekat dengan belajar secara langsung kepada Harjowugu Wibaksa sebagai penari Gathutkaca. Masyarakat pencinta wayang orang Sriwedari kecanduan penampilannya Gathutkaca Harjowugu. Mereka kagum suara dan cèngkok uranurannya, sehingga dulu menjadi omongan dan menjadi model uran-uran cèngkok Harjowugu. Menurut R.Ng. Wiryopradhata selaku manajer wayang orang Sriwedari, bahwa ia mendapatkan kembali Harjowugu, bahkan suaranya lebih bagus, gayanya pun mirip. Seperti 
Harjowugu terutama "gregetnya", namun akhirnya Rusman menciptakan dirinya sebagai Rusman, bukan Harjowugu. Gathutkaca Rusman yang utuh menjadi lain sama sekali berbeda dengan Gathutkaca Harjowugu (Hardjoprasonto, 1997: 132). Nama Rusman Harjowibaksa sesungguhnya nunggaksemi dari nama Harjowugu Wibaksa, artinya adaptasi nama penari rol seniornya merupakan bentuk pewarisan atau transmisi keaktoran sebagai penerus pemain wayang orang Sriwedari.

Sebagai pewaris aktif dominasi otoritas dan kharisma Harjowugu, Rusman bukannya duplikasi atau kopian Harjowugu, tetapi gaya pribadi Rusman merupakan pencerminan keaktoran yang berbeda dengan pendahulunya. Fenomena ini adalah bentuk spirit zamannya yang dibangun oleh rasional tindakan aktor untuk mendapatkan pengakuan masyarakat penggemarnya. Ekspresi individual yang dibangun aktor sudah barang tentu cenderung bersumber pada bentuk-bentuk koreografi yang sudah ada, kemudian dengan diinterpretasikan kedalam nilai-nilai spirit baru sesuai dengan semangat zamannya, yang melahirkan gaya pribadi aktor. Kehebatan Rusman adalah ketika ia mampu belajar dari Harjowugu dan kemudian memberi penafsiran yang lebih pop dari Harjowugu, yang disadari betul oleh Rusman bahwa hal inilah yang dibutuhkan oleh penonton (Rusini, 2003: $\mathrm{x})$.

Kehebatan Rusman adalah kemampuan menafsirkan kemapanan struktur tari ke dalam paradigma baru sesuai dengan semangat zamannya. Keliaran berkesenian diyakini akan melahirkan kejutan-kejutan baru dalam koreografinya dan memunculkan gaya pribadi. Nilai kharismatik keberhasilan Rusman adalah disiplin dan totalitas penghayatan terhadap tokoh wayang yang dibawakan. Wewenang kharismatik merupakan wewenang yang didasarkan pada kharisma, yaitu suatu kemampuan khusus (wahyu, pulung) yang ada pada diri seseorang. Kedudukan pulung tampaknya irasional, namun pulung akan memberi kekuatan pada seseorang yang mendapatkan bimbingan seorang guru spiritual. Disadari bahwa pulung sudah barang tentu tidak dapat diberikan kepada setiap orang, tetapi hanya diberikan kepada mereka yang benar-benar memiliki kualifikasi untuk mendapatkannya. Keseimbangan kekuatan lahir dan batin ikut menentukan apakah seseorang itu akan memperoleh suatu pulung, termasuk niat baik dalam diri seseorang juga menentukan untuk mendapatkan pulung. Di sini sebenarnya dukungan ayahnya yang ikut membantu dalam melakukan beberapa laku tirakat berat, sehingga menjadi seorang penari rol legendaris di zamannya.

Surono sebagai pewaris aktif dari Sastra Dirun pemeran tokoh Petruk legendaris wayang orang Sriwedari sebelumnya, atau Ranto Edi Gudel yang tampil terlebih dulu sebagai pemeran tokoh Petruk sebelum Surono. Kehebatan Surono adalah perjalanan berkesenian telah ia tempuh dengan belajar terlebih dulu dengan tokoh seniman tari dan karawitan dari Kadipaten Mangkunegaran dan Keraton Kasunanan Surakarta, seperti Demang Poncosewaka, RM.Ng. Wignya Hambeksa, dan R.T. Koesoemokesawa. Sikap keras sang guiru itu, tampaknya membentuk kualitas Surono sebagai penari rol yang mumpuni di bidang tari dan karawitan, sehingga wajar ia dipercaya untuk menjadi sutradara wayang orang Sriwedari. Bahkan karya fragmen wayang orang dalam bentuk garapan humor laku kears dipasaran. Akhirnya, Surono bergabung dalam komunitas sempalan wayang orang Sriwedari untuk keperluan tanggapan yang terkenal dengan sebutan "Trio DRS" (Darsi, Rusman, Surono). Melalui kelompok "Trio DRS" ini sebenarnya mereka mendapatkan menghasilan finansial yang mampu meningkatkan kesejahteraan keluarganya. 


\section{Pewarisan Zamrud dari Rusman Harjowibaksa}

Pewaris aktif Rusman di lingkungan internal wayang orang Sriwedari adalah Zamrud Haryo Yekti Wirutomo (42 tahun). Dalam perjalanan berkesenian sebagai penari wayang orang Sriwedari, ia belum pernah memainkan tokoh Gathutkaca ketika Rusman masih aktif sebagai pemain tokoh Gathutkaca. Namun sebagai penari yunior, ia banyak belajar secara tidak langsung dengan Rusman dalam setiap kali pertunjukan. Proses pembelajaran seni panggung ini memiliki keunikan karena faktor interaksi yang berulang-ulang dalam konteks ruang dan waktu dalam struktur sosial seni pertunjukan. Seorang seniman pada dasarnya adalah peniru, sehingga untuk dapat bertahan dibutuhkan komitmen untuk memiliki kemampuan meniru. Kemampuan meniru ini bukan hanya berlaku untuk seorang seniman pop, melainkan juga untuk para seniman elit (Sunardi, 2007: 5). Oleh karena itu, spesifikasi peniru ini menempatkan Zamrud sebagai pewaris aktif Rusman, meskipun demikian ia memiliki kebebasan kreatif sebagai aktualisasi aktor yang mandiri dan produktif.

Zamrud adalah anak bungsu dari 7 bersaudara, ia lahir di Karanganyar tanggal 1 Oktober 1970 dari pasangan Subanto Citroyudana-Srisuyekti. Ibunya langsung meninggal dunia tahun 1970 setelah melahirkan dirinya, ayahnya seorang kepala Sekolah Menengah Pertama yang juga sebagai seniman serba bisa. Bakat seni Zamrud terlihat sejak ia berumur 6 tahun yaitu seni tari, teater dan menyanyi, yang kebolehannya ditampilkan pada acara peringatan hari kemerdekaan Republik Indonesia, acara penikahan, dan sebagainya. Hargiyanto, Paimin dan Anjrah Sri Paramita adalah guru pemimbing seni tari, teater dan menyanyi ketika masih usia anak-anak. Secara formal mulai mengenal wayang orang secara dekat pada tahun 1987 ketika ia mengikuti mata pelajaran di kelas 2 Sekolah Menengah Kesenian
Indonesia (SMKI) Surakarta. Secara informal ia memperdalam seni tari dan wayang orang kepada Tan Guan Him pelatih wayang orang Persatuan Masyarakat Surakarta (PMS) dan Witoyo pelatih tari dan wayang orang di Keraton Kasunanan Surakarta. Selama kurun waktu tahun 1985-tahun 1995, ia berkenalan dan banyak belajar dengan empu tari Solo yaitu S. Maridi, Rusman dan Surono. Bahkan masuk menjadi pemain wayang orang Sriwedari sejak tahun 1990 atas rekomendasi Rusman dan Surono dengan status sebagai Wiyata Bakti tanpa menerima gaji selama 4 tahun dan pada tahun 1994 ia diangkat menjadi pegawai honorer dengan gaji Rp 60.000,-- per-bulan. Pada bulan Juni tahun 1993 ia mengikuti misi kesenian Keraton Kasunanan Surakarta selama 1 bulan di 12 negara Eropa, yaitu menjadi penari tokoh Indrajit dan Jatayu dalam sendratari Ramayana. Pada tahun 2000 secara resmi ia diangkat menjadi pegawai negeri sipil (PNS) dengan golongan II-a, sehingga status ini menjadikan ia sebagai seniman birokrat yang secara rutin bekerja menjadi penari wayang orang Sriwedari, kacuali hari Minggu malam libur dan Senin (hari Senin sekarang diberlakukan libur tidak ada pertunjukan).

Riwayat peran dapukan sebagai penari wayang orang Sriwedari, yaitu periode tahun 1990-1991 masih mendapat peran prajurit atau bala dupak, tahun 1991-1992 sering berperan raksasa Cakil, dan 1992-1994 selama 1 minggu 3 kali berlatih peran antagonis (brantak), perang, olah suara untuk dialog vokal dan nembang ura-ura atau palaran. Kepiawaian dalam menari dan bekal suara yang baik, ia mulai dipercaya peran-peran tertentu, terutama tokoh dugangan seperti Gathutkaca, Burisrawa, Baladewa, Bomanarakasura, Rahwana, dan sebagainya. Sebagai pemeran tokoh Gathutkaca baru dipercayakan kepada Zamrud setelah Rusman Harjowibakso meninggal dunia 19 Oktober 1990, sebab dominasi otoritas dan kharisma Rusman begitu kuat yang tidak memungkinkan ia tampil sebagai pemerankan tokoh 
Gathutkaca. Pemilihan Zamrud sebagai pengganti Rusman karena pertimbangan kualitas artistik, bahwa ia memiliki gaya penampilannya mirip Rusman, meskipun kualitas kesenimanannya belum mampu menyamai Rusman. Seperti kualifikasi keaktoran Rusman sebagai penari rol, Zamrud masuk pada kategori pola perjalanan berkesenian "tegak lurus', artinya bahwa sejak awal Zamrud menekuni jenis kesenian wayang orang gaya Surakarta, yang terbatas pada satu jenis karakter tokoh pewayangan putra gagah dugangan seperti Gathutkaca, Bomanarasura, Baladewa, Burisrawa, Rahwana, Indrajit dan sebagainya.

Zamrud menyadari, bahwa menduplikasi Rusman bukan pekerjaan yang mudah, tetapi membutuhkan komitmen dan kerja keras untuk meningkatkan kualitas pengetahuan dan keterampilan seni wayang orang secara optimal, sehingga ia mampu membawakan karakter Gathutkaca secara baik. Keyakinan atas dominasi otoritas dan kharisma Rusman belum tergugurkan oleh penari-penari yang pernah lahir kemudian. Hal ini menunjukkan, bahwa dominasi otoritas dan kharisma Rusman sebagai penari rol hanya lahir sekali. Sebagai anak zaman, ia lahir dengan kriteria estetika yang berlaku di zamannya dan didukung oleh penggemarnya yang memiliki acuan normatif dengan standar artistik baku menurut estetika keraton. Kehebatan Rusman adalah kualitas tubuh dan suara yang ideal, sehingga muncul pendapat bahwa Rusman adalah Gathutkaca dan Gathutkaca adalah Rusman. Kondisi ideal ini tidak berlaku bagi Zamrud sebagai pemeran tokoh Gahutkaca pengganti Rusman, ia belum memenuhi kriteria ideal pemeran tokoh Gathutkaca, sebab predikat itu sudah menjadi monopoli Rusman.

Konsep kemasan kontemporer ini diawali ketika Zamrud ditanggap main di kantor Gubernur Jawa Tengah pada tahun 1999, ia diminta oleh G.P.H. Heruwasta pimpinan Suryasumirat Mangkunegaran Surakarta untuk menari Gathutkaca Gandrung berkolaborasi dengan $\mathrm{Ki}$
Enthus Susmono seorang dalang wayang kulit kontemporer. Kritikan yang muncul adalah garapan masih tampak konvensional, belum ada upaya pembaharuan yang menjadi magnit membuat penonton tertawa dan terhibur. Kemudian muncul kemasan tari Gathutkaca-Pregiwa lintas jenis kelamin (cross gender) yang dielaborasikan dengan jenis musik pop, dangdut dan campursari, serta kental dengan nuansa humor, tampaknya mampu menjawab selera dan kebutuhan penonton. Karya tari ini memberikan sentuhan estetis kontemporer tokoh Gathutkaca dan Pregiwa kepada penontonnya. Fenomena ini menunjukkan bahwa penonton masa kini membutuhkan sajian baru dan penafsiran baru terhadap tokoh Gathutkaca dan Pregiwa. Penonton tidak lagi mendengarkan tembang dhandhangula atau pangkur, tetapi mendengarkan lagu pop nasional atau asing, dangdut, dan campursari yang akrab di telinga mereka. Sentuhan estetis ini tampaknya mampu menyentuh hati penonton masa kini, sehingga tidak mengherankan apabila tarian ini semakin populer di kalangan masyarakat pendukungnya.

Popularitas tari "GathutkacaPregiwa" lintas jenis kelamin adalah fenomena zamannya, yang khas dan eksotik. Hal ini sesuai dengan latar belakang kebudayaan populer yang menawarkan suatu gaya hidup yang khas dan eksotik (Siregar, 1997: 219). Karya tari ini membawa Zamrud mencapai popularitas di masa kini dan banyak menerima tanggapan para penggemarnya dari berbagai kota di Jawa Tengah seperti Semarang, Surakarta, bahkan sampai ke Bandung (Zamrud, wawancara 14 Juli 2010).

\section{KESIMPULAN}

Sistem pewarisan dalam wayang orang panggung populer tampaknya dihadapkan suatu permasalahan tentang nilai-nilai profesionalisme yang menuntut adanya disiplin diri dan komitmen untuk menggeluti secara total. Pewarisan berlangsung dalam dua 
kategori, yaitu kategori pewarisan keturunan langsung atau anak kandung sanga penari rol, sehingga ia dibesarkan oleh lingkungannya berkesenian. Dalam kasus wayang orang panggung populer, biasanya ia anak tobong yang memungkinkannya dapat melihat langsung proses kreatif orang tuanya, baik dalam setiap pertunjukan maupun dalam setiap kegiatan latihan. Uniknya, pada prakteknya tidak semua anak penari rol tertarik untuk mendapatkan warisan orang tuanya mengikuti profesinya. Hal ini disebabkan oleh faktor internalnya dengan berbagai alasan yang sifatnya subjektif.

Kategori kedua, yaitu pewarisan yang didapatkan dari penari rol yang bukan orang tua kandung, tetapi sebagai seniornya di tempat ia bermain wayang orang. Misalnya, Rusman yang mendapat pewarisan aktif dari Harjowugu Wibaksa, demikian juga Zamrud yang mewarisi Rusman Harjowibaksa. Spirit integritas kategori kedua ini tentu karena pertimbangan ekonomi semata agar ia mendapatkan kharisma dari pencitraan seniornya. Meskipun disadari bahwa peanri rol tidak pernah menciptakan aktor pengganti karena dianggap rivalitas. Fenomena jarak status sosial ini menyebabkan lahirnya penari rol secara tiba-tiba karena seniornya berhalangan datang akibat sakit atau ada keperluan lain yang dianggap penting. Di sini, kategori penari rol biasanya telah memiliki kepandaian dalam bermain wayang orang yang ia pelajari dari tokoh-tokoh seniman tari dan karawitan yang mumpuni di bidangnya.

Dalam mencari solusi tentang sistem pewarisan penari rol dalam wayang orang, tampaknya kita patut bercermin dan beradaptasi dengan sistem pewarisan yang berlaku di teater Kabuki di Jepang, seorang pemain bintang merupakan andalan pencitraan bagi kepentingan bisnis hiburan seni pertunjukan tradisional, yaitu (1) ia harus keturunan langsung dari pemain bintang, $) \backslash(2)$ ia harus menjadi menantu anak pemain bintang; (3) ia harus diambil anak angkat pemain bintang. Transmisi kaderisasi pemain bintang itu disahkan dalam suatu upacara yang diadakan untuk kepentingan itu, yaitu pencitraan pemain bintang sebagai ikon daya tarik penonton.

\section{DAFTAR RUJUKAN}

\section{A. Sumber Tercetak}

Clara van Groenendel, Victoria M. (1987), Dalang Di Balik Wayang, terjemahan. Pustaka Utama Grafiti, Pustaka Grafiti, Jakarta

Dibia, I Wayan, (2004), Pragina: Penari, Aktor dan Perilaku Seni Pertunjukan Bali. Sava Media, Malang.

Hardjoprasonto, Soemardjo,(1997), Bunga Rampai Seni Tari Solo. Taman Mini Indonesia Indah, Jakarta.

Hersapandi, dkk, (1998), "Krisis Wayang Orang di Era Orde Baru”. Penelitian Pada Lembaga Penelitian ISI Yogyakarta, Yogyakarta.

(1994), "Etnis Cina dan Wayang Orang Komersial: Suatu Kajian Sosio-Historits", dalam Jurnal Seni Pertunjukan Indonesia. PT. Gramedia Widiasarana Indonesia., Jakarta.

(1999), Wayang Wong Sriwedari: Dari Seni Istana Menjadi Seni Komersial. Yayasan Untuk Indonesia, Yogyakarta.

Rusini, 2003, Gathuitkaca di Panggung Soekarno. STSI Press, Surakarta.

Siregar, Ashadi, (1997), "Budaya Massa: Catatan Konseptual tentang Produk Budaya dan Hiburan Massa", dalam Lifestyle Ecstasy: Kebudayaan Pop dalam Masyarakat Komoditas Indonesia” editor Idi Subandy Ibrahim. Jalasutra, Yogyakarta.

Soekanto, Soerjono, (1986), Sosiologi Sutau PengantarRajawali, Jakarta.

Sriyadi, (2003), "Surono: 'Petruk' Wayang Wong Sriwedari, Sebuah Biografi”. Tesis untuk memperoleh Derajat Sarjana S-2 pada Program Pascasarjana Universitas Gadjah Mada Yogyakarta, Yogyakarta. 
Sunardi, 2007, Fenomena Bintang, Universitas: Sanata Dharma, Yogyakarta.

\section{B. Sumber Internett}

http://rstb.royalsocietypublishing.org/content/ 364/1528/2429.full.

http://husnimuarif.wordpress.com/tag/emaneman/

http://eprints.uny.ac.id/3767/1/08Martono.pdf 


\title{
REOG OBYOGAN SEBAGAI PROFESI
}

\author{
Oleh: Hendro Martono \\ Dosen Jurusan Tari Fak. Seni Pertunjukan ISI Yogyakarta \\ Email: gendotrie@yahoo.com
}

\begin{abstract}
Abstrak
Zaman telah berubah, penari seni rakyat tidak lagi dilirik orang karena tidak dapat menjadi profesi yang menguntungkan dalam mengais uang. Tidak demikian di reog Obyogan yang hidup di desa-desa sekitar kota Ponorogo Jawa Timur, penari Obyogan bisa menjadi profesi yang lumayan mendatangkan rejeki bagi para gadis remaja. Profesi penari Obyogan bersifat sementara sampai kondisi fisik penari tidak menarik lagi atau sudah menikah. Obyogan berbeda dengan reog Festivalan yang sudah dikenal masyarakat luas, justru penari Obyog menjadi penari utama dengan bergerak goyang pinggul sensual, mirip goyang ngebor dan gergaji di dangdut. Peran Jathil ditransformasikan menjadi peran wanita yang seksi, peran lain dihilangkan. Pemain Dadak Merak masih dipertahankan sebagai ikon reog. Tulisan ini menyoroti upaya-upaya dan manajemen penari Obyog yang terdiri dari: berlatih tari Obyog, mengubah karakter tari, pencitraan, strategi persaingan, pendapatan, pengeluaran dan pemasaran. Profesi penari Obyog yang temporer tetap harus dihargai sebagai pelaku pelestari dan pengembang seni tradisional. Penari Obyog juga membuka lapangan kerja non formal dan mengurangi urbanisasi serta migrasi. Pemerintah wajib memberi penghargaan berupa pelatihan kerja untuk masa datang, dan beasiswa sekolah hingga perguruan tinggi.
\end{abstract}

Keyword: reog, obyog, profesi

\begin{abstract}
Times have changed, folk art dancers are no longer a desirable profession because it isn't profitable in day to day struggle to make ends meet. This isn't the case with reog Obyogan which persists in villages around Ponorogo city in East Java, Obyogan dancer is a lucrative job for teenage girls. The profession of Obyogan dancers is temporary until the dancers are no longer physically attractive or are married. Obyogan is different from reog Festivalan which is already widely known in that the Obyog dancers are the main dancers with their sensual hips movements, like the drill-like or saw-like dance in dangdut. The role of Jathil is transformed into a sexy woman, other roles are removed. Dadak Merak player is still maintained as the icon of reog. This paper highlights the efforts and management of Obyog dancers which consist of: practicing Obyog dance, changing the characterization of the dance, imaging, competitive strategy, revenue, expenses, and marketing. The temporary profession of Obyog dancers must be respected as the conservators and developers of traditional arts. Obyog dancers also opened non formal job vacancy and reduce urbanization and migration. The government must give appreciation in the form of work training in the future and scholarship to college level.
\end{abstract}

Keyword: reog, obyog, profession

\section{Penari Rakyat Sebagai Profesi}

Di zaman sekarang masih adakah beberapa seniman tari yang hidup dari profesi sebagai penari tradisional? Di Sragen yang terkenal seni Tayub, di Indramayu dan Cirebon yang terkenal dengan tarian topeng. Para pelakunya adalah penari profesional dan hanya menggantungkan hidup sebagai penari, walaupun tetap didukung usaha lain untuk menjaga asap dapur terus mengepul. Para penari seni reog dan Jathilan yang banyak di daerah Yogyakarta, tidak menggantungkan hidupnya dari keseniannya. Mereka pada umumnya para petani yang tergabung dalam kelompok kesenian rakyat. Kondisi demikian juga terjadi di kelompok kesenian topeng Malang yang berada di Kepanjen Malang Selatan dan di Tumpang Malang Timur. Para pelaku kesenian topeng adalah para petani, 
tukang ojek dan profesi lainnya. Para pemain wayang wong Sri Wedari di Surakarta sudah diangkat menjadi pegawai negeri. Apalagi para penari di tempat wisata sudah memiliki profesi lain di luar profesi pelaku kesenian tradisional. Sangat jarang orang yang hidup dari kesenian tradisi.

Penulis memiliki teman baik sejak remaja hingga sekarang yang hidup dari kegiatan tari-menari, yaitu Chattam AR. Dari Malang, yang dulunya sebagai penari Ludruk, sebuah seni pertunjukan tradisional dari Surabaya. Kemudian berpindah menjadi pelatih tari gaya Malangan. Hingga saat ini bukan pegawai negeri. Ternyata dapat hidup layak di kota yang kering kesenian tarinya. Sesuatu yang terjadi di Ponorogo, sebuah kota kabupaten yang tersembunyi di antara perbukitan Seribu yang membentang di Jawa bagian Selatan. Ternyata ada satu lahan hidup yaitu: sebagai penari reog Obyog. Pada kenyataannya, para pelaku bisa hidup layak dan berkecukupan. Bukan penari reog kawak atau festivalan yang telah banyak dikenal masyarakat. Namun sebagai penari reog Obyog yang merupakan kreativitas seniman rakyat. Kalau di Sragen dan Indramayu maupun Cirebon, penarinya adalah wanita yang sudah matang usia dan pengalaman. Beda dengan penari reog Obyog yang dominan para gadis remaja yang masih lajang bahkan ada yang baru lulus sekolah menengah pertama (SMP). Ada beberapa yang sudah menikah muda asal masih cantik, menarik dan kualitas teknik tarinya bagus, tetap menjalani penari Obyog sebagai profesi yang mendatangkan uang yang lumayan. Profesi penari Obyogan di desa pinggiran kota Ponorogo menarik diamati dan disosialisasi sebagai satu kenyataan hidup di sudut ruang kesenian yang jauh dari hingar bingar kehidupan urban.

\section{Reog Obyog}

Tari reog Ponorogo sudah terkenal di seantero nusantara dan sudah banyak yang menuliskan secara tektual maupun kontekstual, tetapi yang ditulis adalah reog tradisional atau sering disebut reog Festivalan atau reog Kawak (lama/kuno), karena hanya dipentaskan saat ada festival reog setahun sekali menjelang bulan Suro. Para seniman reog tidak puas kalau hanya pentasnya 1 kali setahun, maka untuk memenuhi hasrat kesenimanannya pada tahun 1984/1985 dibentuklah reog Obyogan oleh tokoh reog yaitu pak Upal yang berasal dari suatu desa Ponorogo (wawancara dengan pak Yuni dan pak Bambang Wibisono diijinkan dikutib, 2008). Tarian garapan baru tersebut berkembang dan dikembangkan sendiri oleh masyarakat sampai mencapai formatnya seperti sekarang ini, yang hanya dikenal di kalangan masyarakat pedesaan.

Reog Obyog sangat berbeda koreografinya dengan reog Festivalan yang telah dikenal oleh masyarakat luas. Walaupun tetap menggunakan unsur-unsur yang sama dengan reog Festivalan, seperti tetap menggunakan penari jathil namun wujudnya berbeda, tetap menggunakan Dadak Merak sebagai ikon reog, serta komposisi musik tarinya berbeda dengan instrumen musik yang sama.

Perbedaan utama dengan reog festival adalah hanya ada dua peran, yaitu: Jathil tanpa membawa kuda kepang dan Barongan (Dadak Merak), peran Bujang Ganong kadang ada dimainkan anak-anak, sedang Klana Sewandono dan Warok dihilangkan. Sehingga koreografi berbeda sangat jauh dengan reog yang dikenal oleh masyarakat luas. Koreografinya berubah menjadi tari pergaulan yang menghadirkan gerak lemah gemulai nan seksi dari penari jathil yang berdandan menor, seronok dan seksi bak penyanyi dangdut.

Pemerintah tidak terlalu banyak turut campur, dibiarkan masyarakat melestarikan Obyogan sendiri yang pada kenyataannya mendapat sambutan antusias yang luar biasa dari masyarakat sampai sekarang. Dimanapun ada pentas reog Obyogan yang biasanya untuk hajatan pernikahan, khitanan dan perayaan hari besar serta peresmian suatu acara, penonton akan berdatangan dari seluruh penjuru pedesaan Ponorogo, apalagi bila penarinya merupakan primadona.

Walaupun demikian terkenalnya reog Obyog di pedesaan Ponorogo, banyak juga warga Ponorogo kota maupun desa yang tidak mengetahui keberadaan Obyogan.

Pemerintah melalui dinas terkait pernah mengadakan pembakuan gerak tari khususnya tarian Jathil sekitar tahun 1993 dan terus berkembang sampai sekarang ini (wawancara 
dengan Bambang Wibisono diijinkan dikutib, 2005). Kelahiran reog Obyog membangunkan gairah baru terutama dari sisi penari Jathil dan pembarong yang semakin meningkat taraf hidupnya. Bagi penari Klana, Bujang Ganong, Warok justru musibah karena jarang pentas karena hanya pentas saat ada festival reog yang diadakan setahun sekali atau pentas apresiasi seni sebulan sekali setiap bulan purnama di panggung permanen alun-alun Ponorogo.

Kata obyog bisa diambil dari salah satu permainan atau komposisi musik tari Barongan (Dadak Merak) atau tabuhan menjelang pentas reog juga disebut Obyog. Ada juga istilah Obyog dari kata byok byog sebuah kosa kata dialektika Ponorogo yang diucapkan dengan berulang maka menimbulkan arti kacau, meriah seperti suasana reog Obyog yang hingar-bingar (Tugas Kumorohadi, 2004: 94). Menurut pendapat penulis sendiri kata Obyog sesuai dengan komposisi gerak tarinya yang dominan bergoyang pinggul serta liukan badan sensual yang menggetarkan atau mengobyog-obyog iman para lelaki. Perlu diketahui struktur Obyog terdiri dari bagian 1 disebut tari Massal 1995, bagian 2 gambyongan, bagian 3 edrek, menari dengan Bujang Ganong dan Dadak Merak (Kumorohadi, 2004:224-227 di Erlina Pantja, 2005: 66).

Penulis pada tahun 2005 berkesempatan melihat dari dekat seni reog Obyog yang berkembang dan beredar di wilayah pinggiran dan pedesaan sekitar kota Ponorogo. Pada waktu itu sedang ada perhelatan pernikahan salah satu warga desa di Barat kota Ponorogo. Para seniman reog menyiapkan diri di salah rumah warga yang jaraknya sekitar $1 \mathrm{~km}$ dari rumah hajatan. Setelah menampilkan diri pada acara pembukaan di rumah warga, rombongan berjalan sambil diiringi tetabuhan gamelan reog yang menimbulkan suasana riang gembira dan semangat. Tidak ketinggalan diikuti ratusan penonton yang setia menjadi penggembira dengan kadangkala menari dengan irama reog. Ada beberapa orang yang menggantikan penari Barong dengan menggenakan Dadak Merak yang beratnya sekitar $50 \mathrm{~kg}$. Ternyata menjadi penari Barong yang menggigit Dadak Merak tidak melalui ritual sakral namun karena latihan yang lama (wawancara dengan pembarong, 2005). Selanjutnya saat berjalan menuju lokasi hajatan, beberapa kali berhenti di tempat strategis untuk memperagakan tarian. penari wanita menjadi tokoh utama menari bebas ala Jaipongan yang erotis diikuti kendang yang mirip Jaipongan pula, tidak ada lagi gerak loncat-loncat naik kuda, perang-perangan yang heroik. Kadangkala penari wanita menari dengan Barong. Nuansa yang hadir justru erotisme mirip pertunjukan dangdut, goyang gerjaji, goyang ngebor, serta gerakgerak erotis dangdut banyak diadapatasi oleh penari Obyog. Penonton yang mengikuti prosesi kebanyakan laki-laki muda yang sedikit mabuk karena minum putihan beralkohol cukup tinggi. Mereka memberikan respon dengan teriakan dan ikut menari dengan penari wanitanya, beberapa di antaranya menggantikan penari Barong yang menggigit Dadak Merak. Para penonton datang dari berbagai daerah yang fanatik terhadap reog gaya baru tersebut. Ada satu aturan yang ditaati bersama antar penonton dan penari, yaitu penonton tidak boleh menyentuh sedikitpun anggota tubuh penari wanita walaupun hanya tangan, niscaya akan dipukuli oleh sesama penonton (Pantja, 2008: 1-4).

Masih di tahun 2005 saat bulan puasa, selama satu minggu penulis bersama-sama grup reog dari Ponorogo menghadiri festival tari di Taipei dan I-lan. Di kesempatan itu penulis manfaatkan untuk mengorek secara mendalam baik dari penari Obyog, maupun seniman reog lainnya, untuk mencari informasi tentang kehidupan para penari reog Obyog saat itu dan perkembangan reog ke depannya.

Pada hari Minggu tanggal 9 November 2008, berkesempatan lagi melihat reog Obyogan kembali di sebuah desa Selatan Ponorogo yang dipertontonkan untuk acara peresmian kolam renang di desa tersebut. Sayang sekali hujan terus menerus jadi tidak bisa menikmati reog Obyog dengan nyaman, justru banyak informasi tambahan yang didapat dari seniman reog yang melihat dan yang sedang pentas reog.

Pemaparan ini akan mengupas manejemen reog masa kini yang disebut reog Obyog ada yang menyebut Obyogan. Sebagai penari Obyogan yang dilakukan oleh remaja 
putri ternyata dapat menjadi mata pencaharian yang lumayan walau hanya untuk beberapa tahun. Eksistensi penari Obyogan ditentukan oleh usia serta keunggulan fisik atau keelokan wajah maupun tubuh, teknik tari bukan utama.

Penari utama Obyog adalah penari wanita dengan tata rias dan busana:

a. Baju Kebayak (bisa warna apapun yang menyolok) berlengan longgar.

b. Imbar semacam kacih besar yang menutup hingga bahu dan dada, ciri khas Obyog.

c. Berkain panjang batik motif parang, dimodel prajuritan.

d. Rambut terurai lepas, mengenakan ikat kepala model Jawa Timuran yang cara pemasangannya kain dalam keadaan basah.

e. Celana panji di atas lutut hampir seperti celana pendek yang ketat, warna hitam dengan hiasan payet di tepinya.

f. Stagen hitam, kamus timang (sabuk).

g. Boro samir dan sampur dua helai, yang depan gendala giri, yang belakang polos dan lebih pendek untuk menambah efek gerak pinggul.

h. stocking warna kulit dan berkaos kaki putih serta sepatu vantoufel $3-5 \mathrm{~cm}$ warna hitam (Pantja, 2005: 45-46).

Tidak berkuda kepang/Eblek. Selama ini yang diketahui penari Jathil berdandan prajurit berkuda kepang tanpa sepatu. Tidak ada peran Warok, Klana Sewandana dan Bujang Ganong, tinggal penari Barong yang mengenakan Dadak Merak. Menurut informasi, penari wanita dapat menjadi hadiah dari seseorang kepada yang punya hajat bisa lebih dari satu dan yang membayar si penyumbang. Makanya penari wanitanya bisa banyak dan menarinya berbeda-beda. Kelak bila orang yang menyumbang punya hajat, harus dibalas juga dengan mengirim penari Obyogan dalam jumlah yang sama atau lebih.

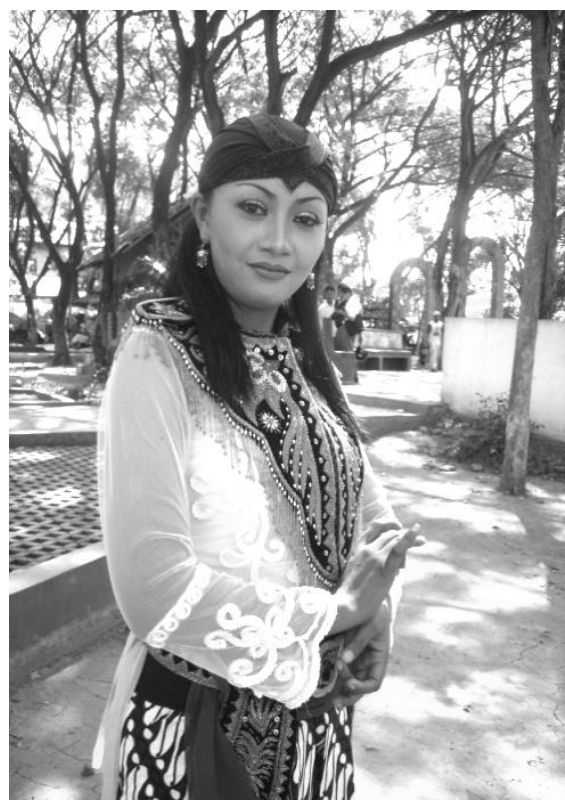

Gambar 1: Kostum penari Obyog lebih feminin daripada Jathil, diperankan oleh Nurul penari

Obyog yang laris (koleksi pribadi, 2009)

Dampak ekonomis bagi penari wanita sangat menguntungkan, bila sekali pentas dibayar sekitar Rp. 200.000,- dalam musim perkawinan satu penari bisa tampil lebih dari 2 kali seminggunya, bila sebulan bisa jutaan yang diraup. Tidak heran bila penari wanita yang terdiri dari para gadis remaja itu mempunyai handphone dan sepeda motor keluaran terbaru. Bila menjadi penari Jathil saja sangat jarang pentas.

Satu hal yang menarik untuk diamati adalah terjadinya pergeseran nilai pada reog Obyog yaitu: peran wanita yang lebih dominan dari pada peran putra, padahal di dalam reog tradisional justru peran-peran putra yang menonjol, peran putri hanya sebagai pemanis. Kehadiran Obyogan di kota santri yang memiliki pondok Gontor, menjadi fenomena yang menarik. Pemerintah kabupaten sengaja membiarkan eksistensi Obyogan yang semakin berkibar, melalui Obyogan para seniman dapat mendapatkan nafkah yang lumayan bila dibandingkan saat pentas reog Festival. 


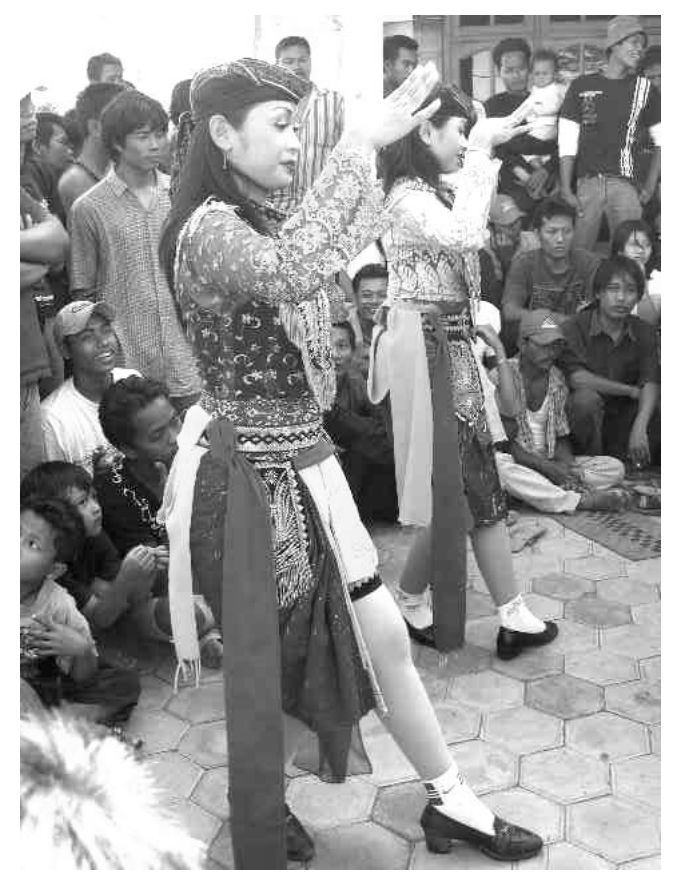

Gambar 2: Penari Obyogan yang mengenakan sepatu dan tidak menggunakan kuda kepang lagi (koleksi pribadi, 2005)

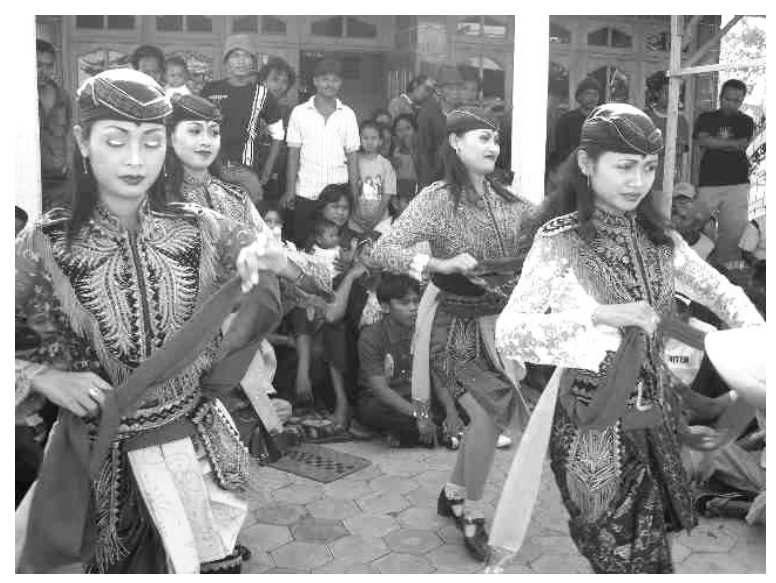

Gambar 3: Penari Obyogan menari dengan goyang pinggul tidak lagi menari prajurit berkuda, lebih disukai masyarakat pedesaan kabupaten Ponorogo (koleksi pribadi, 2005)

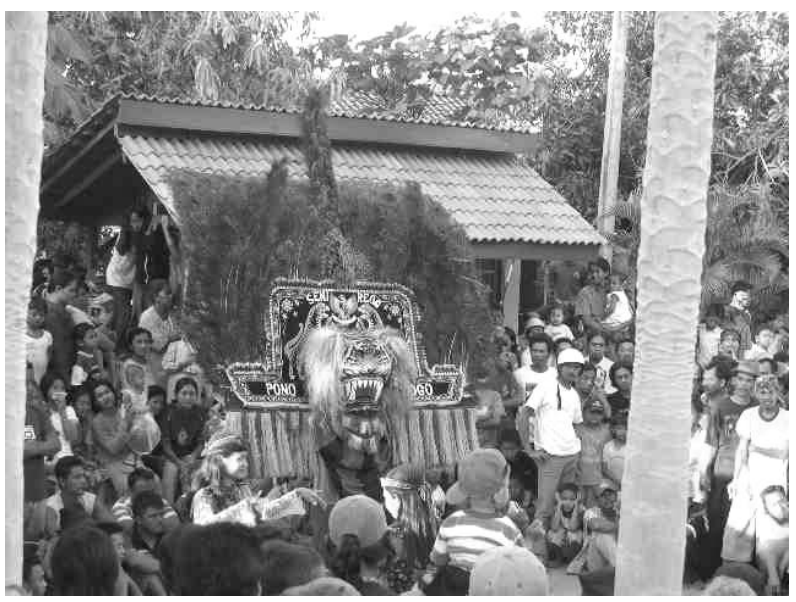

Gambar 4: Antusias penonton Obyogan di pinggiran kota Ponorogo (koleksi pribadi, 2005)

Peranan pemerintah Kabupaten Ponorogo sangat besar dalam pendidikan pelestarian dan pengembangan seni reog Festivalan, karena merupakan identitas dan kebanggaan masyarakat Ponorogo. Peranan tersebut terlihat dari upaya-upaya sebagai berikut:

1. Pemerintah Ponorogo sudah puluhan tahun (lebih dari 20 tahun) menggelar festival reog yang diadakan setiap tahun menjelang bulan Suro, memiliki ketentuan koreografi yang harus ditaati oleh peserta dari manapun. Meluasnya kesenian reog Ponorogo hingga ke luar Jawa seperti Sumatra, Kalimantan bahkan sampai ke Malaysia dikarenakan terjadinya urbanisasi dari sebagian masyarakat Ponorogo dan sekitarnya ke daerah-daerah tersebut di atas. Jadi pelaku penyebaran adalah warga Ponorogo sendiri, bukan orang Sumatra atau Kalimantan yang belajar reog. Termasuk yang di Malaysia, para keturunan orang Ponorogo atau Jawa yang urban di sana sejak sekian puluh tahun yang lalu, membawa kesenian daerahnya.

2. Sektor keuangan dengan menganggarkan dana milyaran Rupiah setiap tahunnya untuk penyelenggaraan Festival Reog selama 5 hari menjelang bulan Suro. Peserta dari berbagai daerah seperti Surabaya, Jember, Lampung, Kalimantan Timur, Jakarta, Yogyakarta, Magelang, Wonogiri, dan setiap kecamatan di 
Kabupaten Ponorogo diharuskan mengirimkan minimal satu kelompok reog dan diberi bantuan biaya produksi Rp. 5.000.000,- (tahun 2005) kekurangannya disuruh mengupayakan sendiri.

3. Pemerintah Kabupaten Ponorogo membangun panggung permanen yang ukurannya sangat luas dan tanpa atap, di alun-alun kota, bila pentas akan dilengkapi tata dekorasi, tata cahaya dan tata suara yang mampu mengangkat prestise sebuah perhelatan besar yang bertaraf Nasional. Penontonnya setiap malam selama lima hari selalu ribuan dengan membayar karcis Rp.3000Rp.10.000,- (tergantung duduk di depan, di tengah dan dibelakang). Di sekitarnya ada pasar malam yang jualan perlengkapan pakaian reog, ved reog dan kaos reog. Jadi nuansa yang hadir betulbetul nuansa reog,

4. Penulis yang pernah berkesempatan menjadi Juri Festival Reog, kagum melihat upaya pemerintah untuk menanamkan kecintaan masyarakat terhadap reog. Salah satunya mengharuskan semua para pria pegawai negeri mengenakan pakaian tradisional reog selama 1 minggu saat Festival Reog digelar, baik saat bekerja maupun saat tidak bekerja, jadinya sehari-sehari dan dimanapun menjumpai masyarakat yang mengenakan pakaian reog. Belum lagi para peserta festival juga mengenakan pakaian demikian, maka semakin mereogkan kota Ponorogo. Ditambahkan pula patung-patung reog di setiap perempatan, di panggung alun-alun serta di empat sudut alun-alun terdapat patungpatung singa (kenapa bukan Harimau), juga di halaman kantor Kabupaten ada patung singa serta dewi Sanggalangit, satu putri dari Kediri yang diperebutan oleh Klana Sewandana dengan Singabarong.

5. Program pelatihan di sanggar-sanggar, di sekolahan dan di kecamatan juga difasilitasi pemerintah.

6. Program pementasan reog yang terjadwal rutin setiap bulan purnama di panggung permanen di alun-alun Ponorogo, yang diisi oleh kelompok-kelompok reog dari kecamatan atau independen yang diberi anggaran oleh pemerintah Rp.1.000.000,disamping dibantu peralatan tata cahaya, tata suara serta promosinya.

7. Pemerintah juga gencar promosi melalui internet dengan memiliki website khusus tentang seni reog festival dan kesejarahannya.

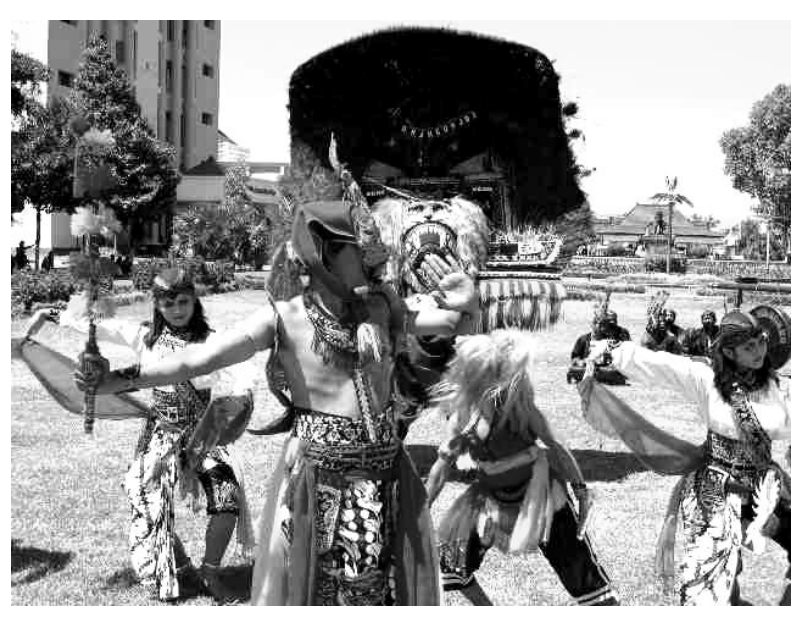

Gambar 5: Reog Festival terdiri dari peran Sewandana (depan), Ganong di tengah, jathil dan barong serta warok di latar belakang (koleksi pribadi, 2005)

Situasi berbalik 180 drajad dengan reog Obyogan, pemerintah tidak memberikan bantuan terhadap Obyogan, karena pemerintah tidak mendukung keberadaaannya, tetapi juga tidak bisa melarangnya disebabkan:

1. Tarian itu berkembang dimasyarakat pedesaan saja atau di pinggiran kota dan lebih disenangi masyarakat, maka Obyogan berkembang sendiri tanpa bantuan pemerintah berkat intensitas permentasan yang sangat sering.

2. Tarian erotis tersebut dianggap menyalahi identitas Ponorogo sebagai kota santri, yang memiliki pondok pesantren terbesar dan terkenal, yakni Pondok Gontor.

3. Sebagai lapangan kerja, para penari Obyogan keadaan ekonominya lebih baik dan bisa hidup layak di usia remaja.

4. Obyogan adalah seni warna lokal yang hanya berkembang di pedesaan Ponorogo saja, belum pernah ada Obyogan dari 
daerah lain. Sehingga tidak perlu ada festival Nasional. Kalau Lomba penari Obyogan pernah ada, hanya sekali.

Tarian Obyog sangat berbeda jauh dengan tarian Jathil, Jathil berkarakter gagah karena sebagai prajurit berkuda (jaman dulu dibawakan oleh laki-laki). Sedangkan Obyogan berkarakter wanita yang genit, geraknya lemah gemulai dan gerak pinggulnya yang seronok. Maka sangat diperlukan pelatihan bila akan menari Obyog. Penari Obyog hampir semuanya bisa menari Jathil, sebaliknya penari Jathil banyak yang tidak bisa menari Obyog. (wawancara dengan Bambang Wibisono diijinkan dikutib, 2005)

\section{Menuju Tari Sebagai Profesi}

Sebagai penari bayaran, para penari Obyogan telah berupaya meningkatkan kualitas teknik tari serta memperluas pergaulannya dengan kelompok-kelompok reog agar mendapat kesempatan pentas yang berkali-kali. Penari adalah manusia juga yang memerlukan beberapa kebutuhan hidup, menurut Abraham Maslow, ada hirarki kebutuhan manusia, yaitu:

1. Kebutuhan fisiologis (makan, sex, hunian).

2. Kebutuhan keselamatan (keamanan diri, keluarga dan asetnya).

3. Kebutuhan milik dan kecintaan (puas sebagai anggota kelompok, berhubungan dengan orang lain, kesenangan serta pengakuan dari pihak lain).

4. Kebutuhan atas penghargaan (reputasi, prestasi, kedudukan atau status dll).

5. Kebutuhan akan kenyataan diri (pengembangan diri semaksimal mungkin, kreativitas, ekspresi diri).

Kebutuhan awal merupakan kebutuhan pokok, setelah terpenuhi akan berlanjut kebutuhan selanjutnya hingga kebutuhan ke lima (Dharmmesta, 2000: 48).

Selaras dengan upaya penari reog Obyog dalam meraih prestasi agar laris manis, maka mencapai tahapan kebutuhan ke 3 hingga ke 4. Kebutuhan milik dan kecintaan, diraih dengan upaya bergabung dengan kelompok seni reog yang terkenal dan menjadi penari yang baik sehingga semakin laris dan banyak pemasukan uangnya.

Upaya-upaya yang dilakukan oleh penari Jathil yang ingin menjadi penari Obyogan, yaitu melalui beberapa tahapan:

1. Belajar Tari Obyog

a. Kebanyakan awal mulanya berangkat dari kesadaran sendiri setelah melihat bahwa menjadi penari Obyogan dipuja-puja dan bisa mendatangkan uang yang tidak sedikit. Walaupun sebagian masyarakat menilai negatif, dalam situasi serba sulit begini menjadi penari Obyogan adalah pilihan yang menggiurkan. Motivasi terjun menjadi penari Obyogan bukan sebagai pelestari budaya, namun berdasarkan pertimbangan ekonomi semata, jadi terpisah antara berkesenian dengan bekerja di sektor seni. (wawancara dengan Wiwid dan diijinkan dikutib, 2005)

b. Dilanjutkan belajar tari Obyog melalui pengamatan, menirukan, mengembangkan dengan ciri pribadi. Tidak ada sanggar maupun kelompok reog yang memberi pelatihan tari Obyog, ada juga yang belatih dari penari senior secara individual. Disebabkan Obyogan bersifat individual tidak berkelompok seperti reog Festival, penari Obyogan bisa bergabung dengan kelompok reog mana saja. Keluwesan teknik tari menjadi modal utama, maka harus berlatih giat selama beberapa bulan dengan uji coba dalam beberapa pentas.

c. Berlatih ekspresi wajah yang selalu tersenyum genit diperkuat lirikan mata yang menggoda. Hal ini penting karena selama menari penari harus mampu menampilkan wajah yang semringah, murah senyum tetapi tidak boleh tertawa lebar nilainya akan turun karena dianggap kurang sopan.

\section{Mengubah Karakter Tari}

Penari Obyog menggambarkan wanita dalam arti sesungguhnya, menurut 
sejarah penari Jathil dilakukan oleh lakilaki yang menjadi simpanan para Warok, jadi ada yang berkarakter banci ada juga yang tetap laki-laki normal. Seiring perubahan jaman, seni reog menjadi seni hiburan dan adanya pelarangan homoseksual secara agamis, maka penari Jathil diganti menjadi wanita semua sampai sekarang agar lebih menarik. Tarian Obyog memperkuat peran wanitanya tidak sekedar jadi prajurit namun menjadi wanita yang seksi yang menggoda iman para lelaki. Jadi ada transisi karakter dalam penari Jathil, maka diperlukan penampilan berbeda yang mendukung kodrati kewanitaannya. Perubahan penampilan adalah meliputi:

a. Gerak tari lemah gemulai, banyak gerak goyang pinggul bahkan memasukkan gerak dangdut yang sensual, semakin pandai bergoyang pinggul semakin disenangi penonton yang kebanyakan para pemuda.

b. Kostum tidak begitu seronok, hanya kebayaknya yang transparan sehingga memperlihatkan perangkat baju dalam yang berupa kaos singlet, serta celana pendeknya yang di atas lutut namun tertutup stocking. Penggunaan ikat kepala dan sampur serta kain panjang adalah sebagai upaya adanya benang merah atau hubungan dengan kesenian tradisional.

3. Pencitraan

a. Mengubah citra dengan menjaga jarak dengan penonton, tidak boleh akrab dan selalu bersikap anggun sebagai seorang wanita terhormat.

b. Perlakuan yang eksklusif, penari Obyog selalu dijemput mobil yang bagus dan diantar sampai tujuan bahkan di depan masyarakat yang sudah berkumpul. Datangnya sering kali terakhir daripada anggota kelompok lainnya. Kesan eksklusif didapatkan dengan cara demikian. Penjemputnya yang menggunakan mobil bisa yang punya hajat atau pihak keluarga atau panitia yang sudah mengetrahui persyaratan bila antar-jemput Obyog. c. Datang ke lokasi biasanya sudah berhias dan mengenakan kostum tarinya yang merupakan milik pribadi, dengan demikian terjadi perubahan sikap dengan membuat jarak dengan penonton atau sering disebut "jaim" (jaga imej), yaitu dengan bersikap anggun tidak mengacuhkan pada ratusan pasang mata penonton yang melototinya. Seolah-olah penari tersebut selebriti bukan dari kalangan masyarakat biasa.

d. Penari Obyogan bisa sebagai hadiah dari seseorang teman kepada temannya yang mengundang reog Obyog untuk hajatan penikahan misalnya. Bila yang punya hajat orang terpandang, maka penari Obyogan bisa banyak sekali karena beberapa diantaranya adalah sumbangan dari teman-temannya. Hal itu harus diketahui dan dicatat bila kelak temannya punya hajatan, dia harus ganti menyumbang penari Obyog. Hadiah penari Obyogan diartikan hanya sebatas menari tidak ada unsur seksualitas.

e. Mengubah penampilan dan Perlakuan eksklusif tersebut perlu dicapai oleh penari Obyog bertujuan untuk menimbulkan psikologis rasa aman, menjaga harga diri dan aktualisasi diri atau merepresentasikan diri sebagai penari yang terhormat. Sesuai dengan hirarki kebutuhan manusia (Dharmmesta, 2000: 48).

\section{Strategi Persaingan}

Persaingan sangat ketat dan profesi penari Obyog berusia pendek, bila sudah tidak menarik lagi penampilannya akan tergeser oleh pendatang baru yang lebih segar dan cantik. Budaya populer sangat kental dalam keberlangsungan tari Obyog, yang harus dituntut menjaga tubuh penari, kecantikan dan keluwesan tariannya. Senantiasa mengikuti mode atau trend tarian dangdut yang menjadi acuannya.

Ada kesadaran bahwa menjadi penari Obyog hanya bersifat sementara. 
Maka mereka berusaha tetap menarik serta mencari peluang pentas sesering mungkin untuk meneguk Rupiah yang banyak. Setelah tidak laku lagi karena dianggap tidak menarik lagi atau usianya sudah di atas 25 tahun, banyak yang beralih menjadi ibu rumah tangga dan bekerja disektor lain. Tidak ada yang berusaha menjadi pengelola penari Obyogan dengan mencari bibit-bibit baru, dilatih dan dipentaskan di bawah naungan kelompoknya. Sehingga tetap ada keterikatan dirinya dengan kesenian reog Obyog. Selama ini yang terjadi terjadi pemutusan hubungan dengan reog begitu seseorang penari mengundurkan diri sebagai penari Obyogan, jadi reog dianggap sebagai lahan kerja temporer. Tidak berpikir idealistis bahwa reog sebagai kesenian warisan leluhur yang perlu dilestarikan dan dikembangkan.

Untuk itu penari Obyog berupaya mencapai:

Memiliki keunggulan fisik dan ketrampilan teknis menari dan merias diri. Memperluas hubungan dengan sesama penari Obyogan dan seniman atau kelompok reog, agar ada jejaring kerja yang solid dan saling menguntungkan.

Melengkapi diri dengan handphone agar mudah dihubungi dan sepeda motor untuk mobilitas yang cepat dan luas.

Melengkapi diri dengan koleksi kebayak yang bagus dan selalu baru setiap ada pentas besar.

Mempromosikan diri saat tampil dengan sebaik-baiknya pada setiap pentas, penonton akan memperhatikan dirinya dan akan mencatat nama maupun nomor teleponnya.

5. Pendapatan

Reog Obyog sangat laris, apabila musim hajatan perkawinan, nadar, bersih desa, sunatan dan tujuh belasan, hari Raya dan lain-lain yaitu pada bulan Agustus Penari-penari panen duit. Reog Obyog sebagai seni profan, telah mengubah paradigma lama tentang fungsi reog tradisional untuk sarana ritual komunitas, bukan untuk mencari nafkah. Diubah oleh reog Obyogan menjadi sarana untuk mencari nafkah terutama bagi para gadis-gadis remaja menjadi penari Obyug.

Honorarium sekali menari Obyog adalah sekitar 100.000-200.000, bayaran tertinggi diterima oleh: pengendang, penari Obyok, penari Barong, pemusik dan pawang, kru.

Namun penari Obyog bisa pentas 2 kali dalam sehari di tempat lain dengan kelengkapan yang sama, tanpa harus ganti rias dan kostum, sebab penari Obyog berposisi individual tidak terikat kelompok tertentu, sehingga bebas bergabung dengan kelompok lain. Sudah hal umum bila suatu kelompok reog yang terdiri dari pemusik, pembarong, pawang adalah anggota komunitas, tetapi penari Obyognya datang dari luar kelompok. Dengan posisi Obyog yang independen berdampak pada pemasukan keuangannya lebih banyak daripada pemusik, pembarong dan pawang yang terikat dalam satu kelompok.

Sebagai contoh pendapatan saat bulan Agustus yang dianggap bulan paling baik dan laris manis, satu penari Obyogan senior seperti Wiwid, dalam satu minggu rata-rata menari 3 kali $\mathrm{x}$ Rp. 200.000,- = Rp. 600.000,- x 4 minggu= Rp. 2.400.000,- Uang sejumlah itu tentunya sangat besar bagi orang desa, makanya banyak remaja putri yang tetarik dengan profesi penari Obyogan dan memang semakin meningkat jumlah penari Obyogan dari tahun ke tahun. Bulan paling sepi adalah bulan Suro, hampir tidak ada tanggapan pentas.

Dapat dikatakan penari Obyog sebagai bintang tamu yang selalu ditunggu-tunggu masyarakat, mereka datang dari puluhan kilometer dari desa lain hanya untuk melihat dan menari bersama Obyog, bila penari Obyognya terkenal seperti Wiwid, Kus dan Utami maka semakin ramai penontonnya.

Strata sosial penari Obyogan berbeda dengan masyarakat umum, karena pendapatannya lumayan besar dibandingkan pendapatan masyarakat desa umumnya. Namun ada yang mencibir karena dianggap penari Obyog sebagai penggoda iman laki-laki, memang ada beberapa kasus yang 
melibatkan hubungan terlarang antara penari Obyog dengan penggemarnya, menjadi istri simpanan. Semua profesi bisa berbuah hal yang negatif, tergantung dari dua individu yang terlibat.

6. Pengeluaran

Sebagai penari Obyogan harus mengeluarkan uamg untuk:

a. Membeli kosmetika seharga $\mathrm{Rp}$. 200.000,- untuk beberapa bulan ke depan. Biasanya belanja saat kosmetikanya sudah habis, tidak setiap saat beli kecuali yang dipakai untuk sehari-hari.

b. Membeli kain untuk kebayak dan ongkos jahitnya, sekitar Rp. 200.000,- sepotong dan bisa digunakan untuk beberapa tahun ke depan dengan bergantian dengan koleksinya yang sudah dimiliki sebelumnnya. Ukuran harus pas dan ketat melekat di badan, jadi harus memiliki sendiri beberapa kebayak dengan warna-warna yang disukai. Pada umumnya sudah bisa menyesuaikan diri antara warna kulit dengan warna kain kebayaknya. Seperti Wiwid yang berkulit gelap tidak akan mau mengenakan warna-warna merah muda dan kuning, lebih senang mengenakan warna biru sedang dengan model kebayak dan kain yang berbeda-beda. Paling sering membeli stocking yang tipis karena mudah robek, namun harganya yang murah tidak menjadikan beban.

c. Membeli hand phone, ada yang seharga di atas Rp. 1.500.000,terutama bagi penari yang laris. Setiap saat harus membeli pulsa. Hubungan bisnisnya sering melalui sms atau telepon, maka alat komunikasi tersebut sata penting.

d. Membeli sepeda motor untuk mobilitas dan menunjukan keberhasilannya.

e. Mencukupi kebutuhan sekunder sehari-hari, para penari yang remaja masih ikut orang tua, maka kebutuhan primernya seperti: makan dan tempat tinggal masih menjadi tanggungan orang tuanya. Walaupun ada penari yang menjadi tulang punggung keluarga dalam perekonomian, karena sudah menikah dan punya anak seperti yang dialami oleh penari Utami, yang saat ini menjadi primadona karena kecantikannya serta keluwesannya yang berhasil menobatkan dirinya sebagai juara 2 dalam lomba penari Obyogan, di bawah Wiwid yang juara 1 .

Bila dihitung-hitung dalam satu tahun, penari yang laris tetap meneguk keuntungan yang lumayan banyak, bisa membeli kesenangan yang diimpikan oleh para remaja pada umumnya yaitu makan minum di restoran, membeli hp produk terbaru, membeli pakaian seharihari yang modis. Namun tidak ada pengeluaran yang ditujukan untuk meningkatkan kualitas teknik tari dan teknik tata rias, yang akan berguna di masa mendatang saat sudah tidak laris menjadi penari, berganti menjadi pelatih tari dan membuka salon kecantikan. Belum ada penari Obyogan yang memikirkan masa depan secara bisnis atau menanamkan modal, masih berpikiran pendek untuk bersenangsenang saja.

Menurut teori manajemen bahwa pelaku harus memiliki standartisasi profesional, apakah penari Obyog memiliki ciri profesional?:

a. Memiliki standar unjuk kerja yang baku dan jelas tentang hal-hal yang dikerjakannya. Sesuai kadarnya memang demikian halnya di dalam penari Obyog, sangat jelas peranannya sebagai penari serta penghibur.

b. Anggota profesi memperoleh pendidikan tinggi yang memberikan dasar pengetahuan yang bertanggungjawab. Bila diukur secara akademis justru penari Obyog lebih banyak para gadis remaja yang lulus SMP atau SMA saja, tidak berpendidikan akademi seni. Namun alam dan lingkungan yang membentuknya, bahkan 
pengetahuan itu tidak akan didapat di bangku akademi.

c. Memiliki lembaga pendidikan khusus yang menghasilkan tenaga profesi yang dibutuhkan. Lembaga atau sanggar tidak ada yang melatih Obyogan, mereka tumbuh sendiri secara independen dan tidak ada latihan yang intensif, bahkan penari Obyog yang sudah laris tidak mau lagi berlatih meningkatkan kualitas teknik tarinya, sudah puas dengan kondisinya dan itupun sudah dapat duit yang cukup.

d. Memiliki organisasi profesi yang memperjuangkan hak-hak anggotanya, serta bertangungjawab untuk meningkatkan profesi yang bersangkutan. Tidak ada organisasi profesi yang menangani, hanya organisasi kesenian atau organisasi kemasyaratan yang mencintai reog Obyog namun tidak jelas bentuknya. Sebab dari kalangan inilah reog Obyog menjadi bertahan hidup.

e. Adanya pengakuan yang layak dari masyarakat. Nampak jelas pengakuan dari masyarakat dengan banyaknya undangan pentas bagi penari Obyog.

f. Adanya sistem imbalan yang memadai, sehingga anggota profesi dapat hidup dari profesi. Belum merata, namun penari Obyog dapat hidup layak. Anggota lain tidak bisa hidup hanya dari reog, maka mencari pekerjaan lain seperti pegawai negeri, pengrajin perlengkapan reog, jadi guru dan sebagainya.

g. Memiliki kode etik yang mengatur setiap anggota profesi. Jelas memiliki kode etik yang terwujud dari masing-masing peran.

7. Pemasaran

Walaupun tidak bernaung pada suatu grup reog, penari Obyogan bergabung dengan sesama penari Obyogan terutama yang senior, guna mendapat kesempatan ajakan pentas meski tanpa bayaran, yang terpenting berlatih tampil di depan masyarakat luas dengan harapan sarana itu sebagai promosi yang ampuh. Apabila dalam perkembangannya ada orang yang tertarik dan memanggil untuk pentas secara independen, merupakan debutnya memasuki arena kompetitif dalam kesenian rakyat yang terlihat lembut namun sesungguhnya sangat keras persaingannya, sangat dimungkinkan menggunakan jasa paranormal (dukun) untuk mendongkrak popularitas. Dunia reog identik dengan dunia mistis.

Pemasaran masih menggunakan gaya tradisional yaitu secara lisan atau dari mulut ke mulut. Biasanya untuk penari Obyogan yang belum dikenal, pemasarannya melalui pihak ke dua yaitu ajakan dari penari Obyogan senior, ajakan dari kelompok reog atau rekomendasi dari orang yang pernah melihat. Sedangkan penari Obyogan yang sudah terkenal biasanya mendapat job kerja langsung dari pihak pertama, melalui sms, telepon atau bertemu langsung setelah pentas atau di kesempatan lain (wawancara dengan Wibisono diijinkan dikutib, 2008).

Biasanya konsumen jarang menanyakan berapa harga kontraknya, karena sudah mengetahui kisaran harga dari keterangan orang lain yang pernah memanggilnya.

Kontrak itu sudah termasuk sewa kostum dan tata rias, tidak termasuk transportasi dan konsumsi. Konsumen harus menyediakan mobil untuk menjemput dan mengantar kembali pulang.

Pemasaran hanya untuk wilayah Kabupaten Ponorogo, masih sangat jarang Obyogan dipentaskan di luar Ponorogo, dikarenakan Obyogan merupakan ekspresi warna lokal asli yang berkarakter khas Ponorogo. Penulis sudah berupaya untuk mementaskan Obyogan di Taipei dalam suatu festival Tari, sebenarnya yang dipentaskan hanya reog Festivalan, tetapi untuk variasi diselipkan Obyogan karena pentasnya perhari 3 kali selama 5 hari. Terlihat Penarinya lebih antusias saat menari Obyogan daripada menari Jathil, mungkin merupakan luapan emosinya 
yang sebenarnya dan kalau menari Jathilan harus mengeluarkan tenaga ekstra kuat sedangkan menari Obyogan lebih santai dan hemat tenaga.

Surut sebagai penari biasanya disebabkan oleh:

a. Sudah menikah dan tidak diijinkan oleh suami.

b. Usia sudah masuk dewasa dan tidak menarik lagi secara fisik.

c. Tidak lagi menjadi anggota kelompok reog (wawancara dengan Bambang Wibisono dan diijinkan dikutib, 2008).

\section{Kesimpulan}

Manajemen Obyog masih tradisional, hanya berjalan secara alami, artinya tidak memiliki ketentuan seperti di dalam manajemen profesional:

Penari Obyog tidak memiliki manager yang bisa mengurusi semua kebutuhan perlengkapan menari, mengurusi kontrak kerja, mencarikan peluang-peluang pentas dan menentukan nilai honorariumnya secara kompetitif. Masih menggunakan manajemen tradisional yaitu semua ditangani sendiri dan hanya mengandalkan nilai kepercayaan.

Tidak ada standart nilai kontrak secara jelas, hanya kisaran harga Rp. 200.000,- sekali pentas.

Penari Obyog banyak yang tidak mau meningkatkan kualitas teknik tarinya dengan berlatih terus menerus guna meningkatkan nilai jual, karena dengan kondisi seperti itu saja mereka sudah dapat uang. Uang adalah segalanya.

Memandang menari Obyogan sebagai suatu pekerjaan yang mendatangkan Rupiah semata, bukan sebagai pahlawan pelestari kebudayaan.

Ada unsur-unsur yang merusak nama baik Obyogan, yaitu setiap pentas beredar minuman keras yang dibawa sendiri oleh penonton dan adanya oknum penari yang bisa dibawa tidur dengan bayaran tertentu, bahkan ada beberapa penari yang menjadi istri simpanan dari oknum tokoh masyarakat. Pemerintah Ponorogo mengalami dilematis, tidak bisa melarang kesenian rakyat yang dicintai masyarakatnya, disisi lain Obyog menjadi identitas asli Ponorogo, karena reog festivalan sudah dimiliki banyak daerah. Maka sikap pemerintah diam pura-pura tidak tahu tentang keberadaannya.

Diperlukan turun tangan pemerintah untuk memberikan wawasan mengelola keuangan bagi penari Obyogan yang umumnya para remaja putri, untuk bekal masa mendatang, agar tidak menjadi pengangguran setelah tidak laku lagi menjadi penari. Program tersebut justru membantu pemerintah untuk mengentaskan kemiskinan dan mengurangi pengangguran dengan membuka lapangan kerja secara mandiri.

Keberadaan penari reog Obyogan perlu dilestarikan keberadaannya, juga akan berefek pada pelestarian budaya tradisi kerakyatan. Juga sebagai salah satu penghalang terjadinya urbanisasi dan migrasi bila tecipta peluang kerja mandiri, tidak tergantung pemerintah. Perlu dicatat Ponorogo merupakan salah satu daerah pensuplai tenaga kerja ke luar negeri. Partisipasi para remaja putri sebagai penari Obyogan juga perlu diberi penghargaan, saat ini sangat jarang anak muda mau berkecimpung di kesenian tradisional. Penghargaan bisa berupa pelatihan kerja, bea siswa sekolah lanjutan atas bahkan kalau bisa sampai perguruan tinggi. Niscaya akan bermanfaat membangun kesenian rakyat Obyogan agar tidak dipandang sebelah mata oleh sebagian orang.

\section{DAFTAR RUJUKAN}

Dharmmesta, Basu Swastha, T. Hani Handoko (2000). Manajemen Pemasara: Abalisa Perilaku Konsumen. BPEE, Yogyakarta

Hartono. 1980. Reog Ponorogo. Proyek Penulisan dan Penerbitan Buku/Majalah Pengetahuan Umum dan Profesi-Departemen Pendidikan dan Kebudayaan: tanpa kota

Indrawijaya, Adam (2000). Perilaku Organisasi. Sinar Baru Algensindo, Bandung.

Kotler, Philip. 1980. Manajemen Pemasaran: Analisis, Perencanaan, Implementasi, dan Kontrol. Terjemahan Hendra Teguh tahun 1997 dkk. PT. Prenhallindo, Jakarta.

Kumorohadi, Tugas. 2004. "Reog Obyogan: Perubagan dan Keberlanjutan Cara penyajian 
JOGED

ISSN: $1858-3989$

dalam Pertunjukan Reog Ponorogo". Tesis S2 Pengkajian Sekolah Tinggi Seni Indonesi Surakarta

Maryaeni, 2005, Metode Penelitian Kebudayaan. PT. Bumi Aksara, Jakarta.

Pantja, Erlina dan Hendro Martono (2009). "Perancangan Koreografi Reog Obyog: Upaya Pengembangan Seni Rakyat Ponorogo". Laporan Penelitian Hibah Bersaing DP2M DIKTI

Permas, Achsan dkk. 2003. Manajemen Organisasi Seni Pertunjukan. PPM, Jakarta

\section{Sumber Lisan:}

1. Bambang Wibisono (45 tahunan), sarjana tari lulusan Sekolah Tinggi Kesenian Wilwatikta Surabaya yang menjadi pegawai di kantor Dinas Kebudayaan dan Pariwisata Ponorogo, dan menjadi pengurus organisasi reog Probo Wengker milik pemerintah Kabupaten Ponorogo.

2. Yuni (40 tahunan), sarjana tari lulusan IKIP Surabaya, sekarang mengajar di sebuah SMP di Kabupaten Ponorogo dan menjadi pelaku serta pengurus grup reog Probo Wengker milik pemerintah.

3. Wiwid (25 tahunan) penari Obyogan pernah meraih juara 1, eksis sebagai penari Obyogan terlaris di tahun 2005. 


\title{
Tari Gandrung Terob Sebagai Identitas Kultural Masyarakat Using Banyuwangi
}

\author{
RINA MARTIARA* dan ARIE YULIA WIJAYA** \\ Jurusan Seni Tari, Fakultas Seni Pertunjukan, Institut Seni Indonesia Yogyakarta, Jalan Parangtritis \\ KM 6,5 Sewon, Bantul, tlp. 0274-375380, email:martiararina@yahoo.com
}

\begin{abstract}
Tari Gandrung Terob sebagai Identitas Kultural Masyarakat Using Banyuwangi. Gandrung Terob merupakan objek yang dikaji guna mengupas pola pikir masyarakat Using Banyuwangi. Sudut pandang yang dipakai adalah Strukturalisme Levi-Strauss. Struktur merupakan susunan bagian-bagian dari suatu sistem yang saling terkait. Segala sesuatu yang memiliki bentuk diyakini memiliki struktur. Struktur kalimat dalam bahasa yang terdiri atas susunan huruf, fonem, dan kata, tidak akan memiliki arti apabila tidak terdapat relasi-relasi yang menghubungkannya untuk mendapatkan struktur yang bermakna.

Keberadaan tari Gandrung Terob dilihat secara menyeluruh, tidak saja sebatas teks dan keterkaitan antar teks saja, melainkan pada konteks sosial budaya masyarakatnya. Melalui cara pandang holistik ini akan ditemukan pola pikir masyarakat Using sebagai pemilik tari Gandrung Terob. Hal yang paling mendasar dalam melihat pola pikir adalah melihat konsep, sehingga Gandrung Terob tidak hanya dilihat sebagai artefak semata melainkan sebagai pandangan hidup atau ideologi masyarakat Using sebagai penyangganya.
\end{abstract}

Key Words: Gandrung Terob, Using, Identitas Kultural

\section{Pendahuluan}

Gandrung Terob merupakan salah satu bentuk kesenian tradisional masyarakat Using Banyuwangi. Kata Ganrung sangat lekat dengan seorang wanita yang berbusana basahan, kain panjang, sampur, kaos kaki berwarna putih, omprog serta membawa properti kipas. Omprog adalah hiasan kepala seperti mahkota yang dibuat dari kulit lembu dengan berbagai ragam pahatan, yang di bagian bawahnya diberi rumbai berwarna kuning emas, sedangkan bagian atasnya dihiasi kembang goyang berwarna emas pula, dengan bentuk kelompok bunga masing-masing berjumlah empat buah yang terbuat dari kulit atau logam, dan ditopang dengan pegas, sehingga saat penari Gandrung bergerak, hiasan pada omprog dapat bergoyang-goyang. $\mathrm{Di}$ dalam pandangan masyarakat Banyuwangi, Gandrung dimaknai dalam beragam arti; yakni dapat berarti sebagai keseluruhan bentuk pertunjukan, sebagai sebutan untuk si penari putri, bahkan wanita yang memakai busana dan tata rias untuk event-event tertentu (misal dalam karnaval) juga disebut Gandrung walaupun ia tidak menari. Adapun terob berarti tenda, yaitu satu bangunan yang dibuat non permanen ketika seseorang memiliki hajat atau gawe. Untuk itu ada perbedaan antara pertunjukan Gandrung yang dipakai sebagai tarian penyambutan tamu dengan Gandrung Terob yang dilaksanakan berkaitan dengan sebuat gawe yang dilakukan oleh seseorang.

Bentuk pertunjukan Gandrung Terob Banyuwangi dipahami sebagai seni yang menghadirkan tari dan vokal, dengan dua orang atau lebih penari puteri yang disebut Gandrung. Pada saat pertunjukan, akan terjadi interaksi antara penari Gandrung, pengrawit, pemaju ${ }^{1}$ dengan penonton. Instrumen pengiring yang digunakan yaitu seperangkat gamelan Banyuwangi yang terdiri dari dua buah biola, kethuk, dua buah kendhang, gong, dan kluncing (triangle). Suara instrumen musik yang digunakan dalam pertunjukan Gandrung Terob terbilang unik dan khas yang ditandai dengan suara biola yang melengking disertai vokal penari Gandrung yang melengking pula.

Tulisan ini memandang tari Gandrung Terob sebagai identitas kultural masyarakat Using Banyuwangi guna mengupas humand mind dengan menggunakan analisis struktural Lévi-Strauss. Fokus strukturalisme Lévi-Strauss bertolak pada

${ }^{1}$ Pemaju adalah penari laki-laki yang menari bersama penari gandrung saat babak paju dalam pertunjukan Gandrung Terob. 


\section{JOGED}

ISSN: $1858-3989$

linguistik, akan tetapi penekanannya bukan pada makna kata, melainkan pada bentuk kata. Prinsip fundamentalnya adalah bahwa pengertian (atau istilah) struktur sosial tidak berkaitan dengan realitas empiris, melainkan dengan model-model yang dibangun menurut realitas empiris tersebut (2009:378). Bangunan dari model-model tersebutlah yang akan membentuk struktur sosial. Melalui Gandrung Terob sebagai teks sekaligus sebagai model akan digali struktur sosial masyarakat Using yang berkaitan dengan nilainilai budaya, pola pikir maupun gejala sosial budaya. Lévi-Strauss memandang bahwa apa yang ada di dalam kebudayaan atau perilaku manusia tidak pernah lepas dari apa yang terefleksikan dalam bahasa yang digunakan. Oleh karena itu, untuk mempelajari kebudayaan atau perilaku suatu masyarakat dapat dilakukan melalui bahasa. Struktur kalimat dalam bahasa yang terdiri atas susunan huruf, fonem, dan kata tidak akan memiliki arti apabila tidak terdapat relasi-relasi yang menghubungkannya. Berkaitan dengan Gandrung Terob yang tersusun dari beberapa unsur, dalam mendeskripsikannya harus dipilah unsur-unsur tersebut beserta penghubungnya untuk mendapatkan struktur yang bermakna.

Penentuan Gandrung Terob sebagai identitas kultural yang dapat mengungkapkan humand mind masyarakat Using Banyuwangi didasarkan pada dua alasan, pertama Gandrung merupakan seni tradisi yang bisa dikatakan paling tua yang ada di Banyuwangi sebagaimana tertulis dalam Serat Bayu yang menyatakan bahwa Gandrung pertama kali muncul, pada saat terjadinya Perang Puputan Bayu. Alasan kedua karena dalam setiap upacaraupacara penting di masyarakat Using, seperti Petik Laut dan perkawinan, selalu menampilkan pertunjukan Gandrung Terob.

\section{Struktur Pertunjukan Gandrung Terob}

Struktur pertunjukan adalah keseluruhan peristiwa yang merangkai kehadiran tari di dalamnya. Gandrung Terob sangat lekat dengan upacara perkawinan, dan khususnya hanya dipertunjukkan pada pesta perkawinan. Pemilihan tari Gandrung Terob dan rangkaian urut-urutan pada pesta perkawinan masyarakat Using menjadi bermakna dan bisa dimengerti dalam totalitas konteks masyarakat Using, dan setiap urutannya tidak akan memberikan penjelasan yang berarti bila dilihat sebagai peristiwa terpisah. Adapun struktur pertunjukan Gandrung Terob dalam
Rina Martiara dan Arie Yulia Wijaya (Tari Gandrung Terob Sebagai Identitas Kultural Masyarakat Using Banyuwangi)

upacara perkawinan terdiri dari 3 rangkaian yaitu: Giro, Topengan, dan Gandrung.

\section{Giro}

Sebelum pertunjukan tari Gandrung dimulai, akan selalu diawali dengan memainkan gendhing yang disebut Giro. Giro adalah bentuk gendhing yang lazim digunakan di wilayah Jawa Timur pada umumnya. Bentuk gendhing giro yang berkembang di wilayah Jawa Timur ini dapat disetarakan dengan gendhing Lancaran yang dikenal di daerah Yogyakarta dan Surakarta, yaitu bentuk gendhing yang dalam satu gongannya terdiri dari 8 ketukan. ${ }^{2}$ Gendhing Giro merupakan bentuk musik instrumental yang memiliki beberapa fungsi, antara lain:

a. Sebagai tanda bahwa akan ada pertunjukan Gandrung di tempat tersebut, yang bagi masyarakat sekitar merupakan undangan untuk turut hadir berpartisipasi di dalam kegiatan tersebut.

b. Sebagai pengawal pertunjukan Gandrung.

c. Sebagai musik pengiring kehadiran tamutamu undangan yang merupakan wujud penghormatan tuan rumah kepada tamu-tamu yang menghadiri acara.

d. Sebagai pengisi waktu kosong sebelum pertunjukan dimulai, saat menunggu penari Gandrung berdandan.

\section{Topengan}

Di beberapa kelompok kesenian Gandrung Terob, pada bagian pertunjukan diawali dengan tari yang disebut dengan Topengan. Topengan ini merupakan tari yang menggambarkan kesatria yang dilakukan sebelum pertunjukan tari Gandrung Terob dimulai. Topengan dilakukan oleh salah seorang penari Gandrung yang memakai kostum celana panji dan kemben (bukan menggunakan kostum tari Gandrung). Menurut cerita turun temurun, penari Gandrung yang pertama kali menarikan Topengan sebelum pertunjukan Gandrung Terob dimulai bernama Awiyah, pada sekitar tahun 1930-an. ${ }^{3}$ Urutan pertunjukan

\footnotetext{
${ }^{2}$ Wawancara dengan Untung Muljono pada tanggal 4 Desember 2010

${ }^{3}$ Menurut Fatrah Abal, Awiyah merupakan penari Gandrung yang berasal dari daerah Mangir, tetapi Awiyah menarikan tari Topengan pertama kali di Desa Bakungan. Pernah dijumpai pula pertunjukan Gandrung yang diawali dengan tari Bondan pada tahun 1950-an. Hal ini menunjukkan adanya pengaruh Jawa Kulonan pada kesenian Gandrung saat itu. Jawa Kulonan merupakan istilah yang digunakan masyarakat Using terhadap orang-orang Jawa yang berasal dari Yogyakarta, Solo, dan sekitarnya.
} 
selanjutnya adalah Gandrung yang merupakan inti dari keseluruhan pertunjukan Gandrung Terob. Untuk itu struktur tari Gandrung Terob diuraikan dalam deskripsi yang lebih terperinci.

\section{Struktur Tari Gandrung Terob}

Tari merupakan salah satu bentuk seni pertunjukan yang kompleks. Ia tidak hanya dipahami sebagai wujud dari gerak semata, melainkan keseluruhan peristiwa yang merangkai hadirnya wujud itu di dalam masyarakat. Dalam pertunjukan tari terdapat banyak unsur-unsur yang mendukung seperti musik, properti, kostum, tata rias, setting, tata cahaya, dan tubuh penari itu sendiri. Tari juga dapat dikatakan sebagai media komunikasi, karena gerak yang ada dalam tari adalah bahasa tubuh. Bahasa tubuh yang muncul merupakan ungkapan perasaan dari masyarakat pemiliknya. Berkaitan dengan tari yang merupakan ungkapan perasaan dari masyarakat pemiliknya, tari Gandrung merupakan bentuk ungkapan yang jujur mengenai perasaan dan pengalaman masyarakat Using yang mencerminkan nilai-nilai humand mind (nalar kemanusiaan) di balik bentuk pertunjukan. Struktur tari Gandrung Terob terdiri dari 3 babak, yaitu Jejer, Paju, dan Seblangseblang. Pertunjukannya biasanya dimulai pada pukul 21.00 dan berakhir pukul 04.00 dini hari, berlangsung sekitar 7 jam.

\section{Jejer}

Pada babak ini penari Gandrung memulai pertunjukan dengan berdiri di tengah-tengah kalangan (arena pertunjukan) dengan melantunkan Gendhing Padha Nonton. Saat menyanyi, ia menutupi wajahnya dengan membentangkan kipas di depan mulutnya. Sebelum melantunkan gendhing Padha Nonton, penari Gandrung menari sesuai dengan ketukan musik pengiringnya. Tarian ini disebut Jejer $^{4}$ dan berlangsung sekitar 15 sampai 20 menit. Gendhing Padha Nonton wajib dilantunkan pada babak ini, terdiri dari delapan bait dan setiap baitnya terdiri dari empat lirik. Delapan bait dalam lirik ini menggunakan bahasa Using Cara Besiki. Satu bait dalam tembang Jawa disebut juga sak pada. Pada perkembangan sekarang ini Gending Padha Nonton dalam praktiknya hanya dilantunkan dua bait pertama.

${ }^{4}$ Jejer berarti berjajar, dalam bahasa Jawa disebut jéjér. Istilah jejer digunakan sebagai nama babak pertama dalam pertunjukan tari Gandrung Terob Banyuwangi, karena pada babak pertama penari Gandrung memulai atraksinya dengan berjajar.
Pemendekan delapan bait lirik Padha Nonton menjadi hanya 2 bait saja, dikarenakan pada sekitar tahun 90-an para peminat kesenian Gandrung mulai terpengaruh adanya ekses minuman keras saat pertunjukan. ${ }^{5}$ Hal ini seringkali menyebabkan kegaduhan dan keadaan yang kurang menyenangkan yang diakibatkan ulah sebagian penonton yang mulai kehilangan kendali kesadaran diri akibat pengaruh minuman keras tersebut. Oleh karena itu dengan tujuan agar tidak menimbulkan hal yang tidak diinginkan tersebut maka waktu dipersingkat dengan cara memotong delapan bait lirik lagu menjadi hanya dua bait saja.

\section{Paju}

Pada babak paju penari Gandrung akan memberi kesempatan kepada para penontonnya untuk maju bersama dalam kalangan (arena pertunjukan) guna menunjukkan kemampuan mereka dalam bidang seni tari atau seni bela diri. Gendhing-gendhing yang digunakan sebagai pengiring dalam babak ini sangat beraneka ragam dan bisa disesuaikan dengan permintaan penonton. Dalam pengaturan urutan penonton yang menari bersama Gandrung, diatur oleh seorang laki-laki pengatur acara yang disebut Pramugari atau Gedhog.

\footnotetext{
${ }^{5}$ Dari sudut pandang ajaran agama Islam, minuman beralkohol haram hukumnya untuk dikonsumsi. Hal ini berbeda dengan konsep minuman beralkohol yang tidak jarang ditemui dalam seni tradisi rakyat. Minuman beralkohol dalam seni tradisi rakyat dianggap memberikan efek keberanian agar penari menari lebih bebas, spontan, dan tanpa beban. Ketika penari dalam keadaan tidak sadar dipercaya mampu untuk berhubungan atau melakukan kontak dengan dunia magis yang berhubungan dengan para leluhur. Tujuan meminum minuman beralkohol diasumsikan juga bahwa si penari bukan lagi 'mejadi dirinya sendiri', melainkan menjadi sosok lain yang nantinya akan menjadi wadah atau sarana pertemuan antara yang ghaib, yang diharapkan dapat mempengaruhi manusia dalam hubungannya dengan yang di atas.
} 


\section{JOGED}

ISSN: $1858-3989$

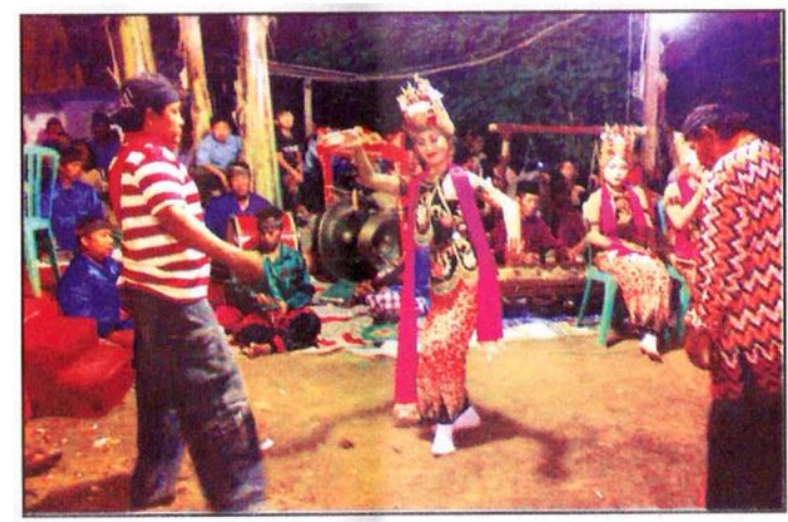

Gambar 1: Pertunjukan Gandrung dalam babak раји

(sumber:Dariharto, 2009, Kesenian Gandrung

Banyuwangi, Dinas kebudayaan dan Pariwisata Banyuwangi, p. 44.

\section{Seblang-seblang}

Dalam babak ketiga penari Gandrung wajib melantunkan gendhing sebanyak lima buah antara lain gendhing Seblang Lokinta, Sekar Jenang, Kembang Pepe, Sondreng-sondreng, dan Kembang Dirma. Seblang-seblang berasal dari kata seblang ${ }^{6}$ yang berarti trance yaitu keadaan seseorang yang sedang terputus dengan sekelilingnya, seperti orang meditasi. ${ }^{7}$ Seblang juga diartikan keadaan orang yang sedang kesurupan atau kemasukan roh halus sebangsa jin atau arwah orang yang sudah meninggal dunia. Ketika penari Gandrung melantunkan gendhing-gendhing wajib di babak ini dengan penuh penghayatan, maka penari Gandrung bisa kesurupan atau dalam keadaan tidak sadar. Hal tersebut menyebabkan babak akhir pertunjukan Gandrung disebut dengan babak Seblang-seblang.

\section{Analisis Teks Pertunjukan}

Memandang tari dari sisi bentuk atau teks, dapat diuraikan antara lain: pelaku pertunjukan, tata busana dan tata rias, waktu dan tempat pertunjukan, pola lantai, dan gerak tari.
Rina Martiara dan Arie Yulia Wijaya (Tari Gandrung Terob Sebagai Identitas Kultural Masyarakat Using Banyuwangi)

\section{Pelaku Pertunjukan}

Pelaku pertunjukan adalah semua orang yang turut berpartisipasi dalam sebuah pertunjukan. Pelaku pertunjukan dalam Gandrung Terob terdiri dari penari Gandrung, pemaju, pemusik, pengudang, dan gedhog. Penari Gandrung ada dua macam, yaitu penari Gandrung keturunan dan bukan keturunan. Penari Gandrung keturunan yaitu penari Gandrung yang memiliki darah keturunan dari seorang penari Gandrung, bisa diperoleh dari ibu atau nenek. Penari Gandrung bukan keturunan adalah penari Gandrung yang berasal dari masyarakat biasa yang tidak memiliki garis keturunan dari seorang Gandrung. Pemaju adalah orang yang menari bersama penari Gandrung saat babak Paju. Ретаju berasal dari tamu dan penonton yang hadir dalam pertunjukan Gandrung Terob.

Pemusik dalam pertunjukan Gandrung Terob biasanya berasal dari masyarakat Using yang senang akan kesenian. Ada pemusik yang memiliki latar belakang pekerjaan sebagai petani, pegawai, buruh, dan pedagang. Ada pula yang berprofesi sebagai pemusik untuk mata pencahariannya. Pemusik dalam pertunjukan Gandrung Terob pada umumnya tidak mengenal notasi musik secara formal, mereka bisa memainkan alat musik secara otodidak. Mereka mengandalkan indera pendengaran dan mengasah kepekaan rasa terhadap musik yang mereka mainkan.

Pengudang yaitu seorang panjak atau wiyaga ${ }^{8}$ yang bertanggung jawab memandu penari Gandrung selama pertunjukan berlangsung. Pengudang disebut juga Tukang Kudang karena selama pertunjukan selalu melontarkan celotehan-celotehan yang lucu atau bersifat komedi. Gedhog adalah seorang yang bertugas sebagai pengatur acara dalam pertunjukan Gandrung Terob. Gedhog mengatur giliran para pemaju untuk menari bersama penari Gandrung.
${ }^{6}$ Di Banyuwangi, daerah Oleh Sari dan Bakungan terdapat pula upacara sakral yang disebut Seblang. Seblang merupakan upacara sakral yang berkaitan dengan upacara magis untuk mendatangkan roh halus, roh leluhur atau Sang Hyang.

${ }^{7}$ Wawancara dengan Hasnan Singodimayan pada tanggal 27 Februari 2010

\footnotetext{
${ }^{8}$ Panjak atau wiyaga yaitu pemain musik tradisional. Dalam pertunjukan Gandrung Terob, panjak digunakan sebagai sebutan untuk pemusik.
} 


\section{Tata Busana dan Tata Rias Pelaku Kesenian Gandrung Terob}

Busana penari Gandrung terdiri dari omprog, basahan, sampur, kain panjang, kaos kaki berwarna putih, dan membawa properti kipas. Basahan, yaitu busana penari Gandrung yang terdiri dari kemben, kelat bahu, ilat-ilat, pending, semong, dan oncer.

Tata rias yang digunakan oleh penari Gandrung yaitu rias korektif atau riasan yang bertujuan mempercantik wajah penari. Tidak terdapat pakem atau aturan khusus dalam tata rias yang dikenakan, akan tetapi penari Gandrung wajib menggunakan lulur yang diusapkan merata ke seluruh bagian tubuh. Lulur yang digunakan biasa disebut dengan boreh. Boreh yang digunakan berwarna kuning emas yang dipercaya memiliki unsur magis sebagaimana warna kuning emas yang merupakan lambang dari keagungan dan menolak bala.

Kostum yang dikenakan oleh wiyaga atau pemusik yaitu atasan lengan panjang dan celana panjang yang diseragamkan warnanya. Tidak terdapat ketentuan khusus untuk kostum pemusik. Aksesoris yang dikenakan pemusik adalah udeng, yaitu hiasan dari kain khas Banyuwangi yang dikenakan di kepala.

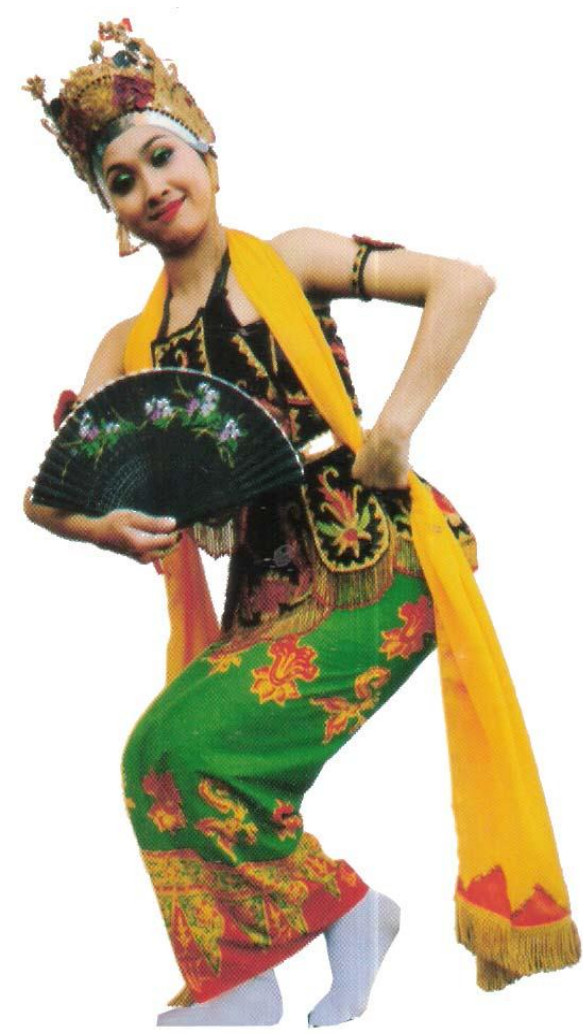

Gambar 2: Seorang penari Gandrung (Foto: Arie Yulia Wijaya)

\section{Waktu dan Tempat Pertunjukan}

Pertunjukan Gandrung dilaksanakan pada malam hari, beberapa saat setelah waktu Sholat Isya' hingga menjelang waktu Subuh atau sekitar pukul 21.00 sampai 04.00. Tempat pelaksanaan pertunjukan Gandrung Terob yaitu di halaman rumah, di dalam tenda hajatan atau terob. Arena pertunjukannya disebut dengan kalangan.

Gandrung Terob diselenggarakan setelah acara inti dari hajatan dilaksanakan. Apabila dalam pernikahan, maka Gandrung Terob dipertunjukkan setelah acara akad nikah berlangsung dan apabila dalam acara khitanan, si anak lelaki sudah dikhitan. Pada umumnya kelompok kesenian Gandrung Terob memiliki pembagian waktu dalam pertunjukannya. Hal ini bertujuan untuk menyiasati agar pertunjukan Gandrung Terob dapat selesai tepat waktu, tidak sampai melampaui setelah waktu Subuh, walaupun tamu yang datang banyak jumlahnya. Pembagian waktu dalam pertunjukan Gandrung Terob: 


\begin{tabular}{|c|c|c|}
\hline \multirow{2}{*}{$\begin{array}{c}\text { Babak dalam } \\
\text { Pertunjukan } \\
\text { Gandrung }\end{array}$} & Jumlah tamu banyak & Jumlah tamu sedikit \\
\cline { 2 - 3 } & $20.30-21.00$ & $20.30-21.00$ \\
\hline Giro & $21.00-21.30$ & $21.00-21.30$ \\
\hline Jejer & $21.30-03.30$ & $21.30-01.30$ \\
Paju & $\begin{array}{c}\text { (setelah babak ini kelompok } \\
\text { kesenian Gandrung istirahat } \\
\text { hingga waktu Sholat Subuh } \\
\text { selesai) }\end{array}$ & $\begin{array}{c}\text { penari Gandrung istirahat sekitar } \\
\text { (setelah babak init) }\end{array}$ \\
\hline Seblang-seblang & 04.00-05.00 & $02.00-03.00$ \\
\hline
\end{tabular}

\section{Pola Lantai}

Pola lantai penari Gandrung sebagian besar berbentuk lintasan yang melingkar atau mengitari arena pertunjukan. Pada babak Jejer, penari Gandrung baris berjajar di arena pertunjukan dan di bagian akhir yakni babak Jejer penari Gandrung melakukan gerak tari langkah nyiji ${ }^{9}$ dengan melintasi arena pertunjukan. Pada saat babak Paju, penari Gandrung mengawali babak dengan menari dan melantunkan gendhing permintaan tuan rumah di atas pelaminan. Setelah semua permintaan gendhing dari tuan rumah dilantunkan, penari Gandrung mulai turun ke arena penonton dan kemudian menyanyi serta menari bersama tamu. Tamu dan penonton yang menari bersama penari Gandrung disebut pemaju. Pada babak terakhir yaitu babak Seblang-seblang, penari Gandrung menari dan melantunkan gendhing penutupnya di tengah-tengah arena pertunjukan.

\section{Gerak Tari dan Instrumen Pengiring}

Tidak terdapat pakem atau aturan khusus mengenai motif-motif gerak yang ada dalam pertunjukan Gandrung, namun tiap gerakan harus sesuai dengan ketukan pada musik pengiringnya. Saat ini motif gerak dalam Gandrung mengalami perkembangan karena telah banyak dikreasikan oleh para pelakunya. Motif gerak yang banyak dikreasikan ada pada bagian Jejer, sebelum penari Gandrung

${ }^{9}$ Langkah nyiji yaitu gerak tari dengan langkah kaki melangkah seperti orang berjalan yang disesuaikan dengan tempo musik pengirngnya. melantunkan gending Padha Nonton. Ada kelompok kesenian Gandrung yang memasukkan unsur gerak tari jaipongan, kuntulan, jaranan, bahkan goyang pinggul dengan berbagai variasinya.

Menurut Bapak Serade, yang perlu dijadikan pegangan oleh penari dalam pertunjukan Gandrung yaitu bunyi gong cilik harus jatuh pada kaki kiri sedangkan bunyi gong gedhe jatuh pada kaki kanan. Dalam pertunjukan Gandrung, penari laki-laki tidak boleh mengangkat kaki terlalu tinggi, hanya di bawah lutut untuk ukuran angkatan kakinya, berbeda dengan gerak kaki dalam tari Jawa yang disebut dengan junjungan. Menurut masyarakat Using, gerak mengangkat kaki yang terlalu tinggi dianggap kurang sopan (bengkak).

Instrumen pengiring yang digunakan yaitu seperangkat gamelan Banyuwangi yang terdiri dari dua buah biola, kethuk, dua buah kendhang, gong, dan kluncing (triangle). Suara instrumen musik yang digunakan dalam pertunjukan Gandrung Terob yang merupakan khas Banyuwangi adalah suara biola yang melengking, disertai vokal penari Gandrung yang melengking pula.

\section{Struktur Pola Pikir Masyarakat Using Banyuwangi}

Berbagai penanda dalam pertunjukan tari Gandrung Terob adalah sebuah struktur. Struktur merupakan unsur-unsur pembangun yang saling berkaitan dalam sebuah karya seni, oleh karena itu setiap karya seni selalu memiliki struktur. Memaknai struktur tari Gandrung Terob berarti memaknai unsur-unsur yang terdapat dalam tari 
tersebut. Dalam tulisan ini pemaknaan struktur tari Gandrung Terob hanya dibatasi pada unsur dramatik, bentuk gerak, koreografi, dan jenis kelamin penari. Pemilihan tersebut didasarkan atas relasinya tari Gandrung Terob dengan konsep kesuburan.

Babak jejer menjadi penanda bahwa pertunjukan tari telah dimulai dan mengajak orangorang untuk bersama-sama menonton pertunjukan. Hal itu dibuktikan dengan gendhing wajib yang harus dimainkan dalam babak ini yaitu gendhing Padha Nonton. Babak paju berlangsung tengah malam sampai menjelang pagi, hal ini dimaksudkan memberikan ruang khusus kepada laki-laki dewasa untuk berekspresi, menunjukkan kemampuannya dalam bidang seni tari. Sebagaimana Toer dalam Mangir (2000:14) mengatakan, kehebatan seorang laki-laki Jawa dapat diukur dari "ketangkasannya di medan perang dan kelincahannya di medan tari".

Dalam upacara perkawinan, pemaju yang pertama kali dipersilakan untuk menari adalah pengantin laki-laki. Hal itu menjadi semacam petanda ritual bukak kelambu atau malam pertama. Babak seblang-seblang berlangsung menjelang subuh oleh karena itu disebut juga seblang subuh. Kata seblang juga berarti 'keadaan seseorang pada kondisi kosong', hal itu menjadi petanda berserah diri kepada Yang Maha Kuasa. Rangkaian struktur dramatik tari Gandrung Terob tersebut seakan menjadi petanda siklus hidup manusia, yaitu lahir atau anak-anak melalui babak jejer, kemudian dewasa dan mengenal pasangan sampai akhirnya menikah melalui babak paju, dan yang terakhir babak seblang-seblang sebagai siklus manusia tua yang harus lebih mendekatkan diri kepada Sang Pencipta.

Berbagai bentuk gerak yang tampak dari ketiga babak yaitu jejer, paju, dan seblang-seblang menjadi petanda bahwa, gerak pada babak jejer adalah gerakan awal atau pertama, dapat juga dimaknai sebagai gerakan anak-anak yang baru belajar, sehingga gerakan tersebut terlihat lebih rapi dan seirama dengan musik. Sebagaimana seorang anak-anak yang masih polos dan jujur. Hal tersebut tentu saja berbeda dengan gerak pada babak paju yang lebih 'liar' dan mengandalkan improvisasi. Seakan mengingatkan pada masa remaja yang bebas dalam mencari eksistensi diri. Semakin tambah usia maka seseorang juga akan semakin tenang dan merunduk, sebagaimana terlihat dalam gerak pada babak seblang-seblang. Seorang yang sudah tua diharapkan lebih membersihkan diri dan lingkungannya, yaitu menyapu hati dan keluarganya dari berbagai perbuatan dosa.

Jenis kelamin penari menjadi penanda yang penting dalam melihat makna yang terkandung di sebuah tarian. Hal tersebut juga terlihat dalam tari Gandrung Terob, semua penarinya adalah wanita dan pada saat adegan tertentu ( laki-laki untuk diajak menari bersama. Pada fase inilah sebetulnya menjadi kunci sebagai petanda fertility dance, yaitu bertemunya antara laki-laki dan perempuan. Penari wanita melambangakan bumi dan penari laki-laki adalah benih yang nantinya akan bertemu dalam babak paju. Salah satu penanda koreografis yang ditunjukkan dalam pertunjukan tari Gandrung Terob adalah penggunaan pola lantai yang melingkar. Dalam pertunjukan Gandrung Terob penggunaan pola lantai melingkar dimaknai sebagai wujud rasa kebersamaan masyarakat Using dalam mensyukuri berkah kesuburan dari Dewi Padi. ${ }^{10}$ Berbagai bentuk lingkaran yang ada menyiratkan sebuah makna kesatuan atau keutuhan antara diri manusia dengan alam. Melalui kesatuan atau keutuhan tersebut akan menghasilkan pertemuan yang diharapkan mencapai 'kesuburan', baik bagi benih padi yang ditanam maupun bagi pasangan pengantin.

Perkawinan dalam masyarakat Using di Banyuwangi selalu menyertakan pertunjukan tari Gandrung Terob, sehingga dalam upacara tersebut terjadi dua peristiwa yaitu, peristiwa perkawinan dan peristiwa tari. Kedua peristiwa tersebut tidak bisa dipisahkan, karena Gandrung Terob diperlukan sebagai sarana upacara perkawinan, sedangkan perkawinan itu sendiri tempat di mana tari Gandrung Terob dilangsungkan. Fungsi Gandrung Terob dalam upacara perkawinan masyarakat Using di Banyuwangi selain sebagai kekuatan magi dan doa untuk kesuburan, juga berisi petuah atau nasihat-nasihat dalam mempersiapkan hubungan berumah tangga. Misalnya saja bagaimana seorang suami dan isteri harus bersikap. Tarian tersebut juga memberikan gambaran sebuah rumah tangga yang harmonis, berjalan dalam keseimbangan, dengan peran dan tanggung jawab masing-masing orang pada posisinya. Seorang suami sebagai kepala rumah tangga bertanggung jawab pada urusan 'luar' sedangkan isteri sebagai ibu rumah tangga bertanggung jawab pada urusan 'dalam'.

\footnotetext{
${ }^{10}$ Wawancara dengan Cak Wan pada tanggal 6 Oktober 2010
} 


\section{JOGED}

ISSN: $1858-3989$

Pertunjukan Gandrung Terob dalam upacara perkawinan masyarakat Using di Banyuwangi sarat dengan posisi berpasangan, seperti laki-laki dan perempuan, ordinat dan subordinat, luar dan dalam, keras dan lembut, menguasai dan dikuasai, dan lain sebagainya. Dalam pertunjukan Gandrung Terob, berbagai posisi berpasangan tersebut saling berelasi, sehingga menciptakan sebuah posisi baru. Posisi baru inilah yang dalam pandangan Victor Turner disebut sebagai liminal, yaitu posisi ambang yang berada dalam dua posisi yang berbeda. Liminalitas berarti tahap atau periode waktu di mana subjek ritual mengalami keadaan yang ambigu yaitu "tidak di sana dan tidak di sini". Liminal sering diartikan sebagai peraliha. (Winangun, 1990:31). Posisi-posisi berpasangan dalam setiap fenomena kebudayaan selalu terjadi, hal itu sesungguhnya menunjukkan bahwa sebuah kehidupan telah terjadi. Persinggungan dari kedua posisi berpasangan tersebut yang dianalisis dalam tulisan ini.

Berbagai posisi berpasangan dalam tari Gandrung Terob menunjukkan bahwa penari berada dalam kawasan liminal, baik di dalam peristiwa tari maupun dalam kehidupan sosial. Dalam peristiwa tari, posisi penari Gandrung Terob adalah pemain yang sedang berhadapan langsung dengan penonton. Jarak antara penonton dan ruang permainan telah terbagi, namun seorang penari Gandrung harus sesekali memecah jarak tersebut, sehingga memungkinkan terjadinya interaksi yang akrab antara pemain dan penonton. Seni pertunjukan kerakyatan seperti halnya tari Gandrung Terob, tampaknya menyadari bahwa meleburnya antara ruang permainan dan penonton, mampu menyatukan energi atau kekuatan untuk mempengaruhi alam.

Posisi berpasangan yang lain tampak juga dalam pertunjukan tari Gandrung Terob. Pertunjukan Gandrung Terob yang dibagi menjadi tiga babak yaitu jejer, paju, dan seblang-seblang berpasangan dengan anak-anak, dewasa, dan tua. Jejer sebagai babak pembuka berpasangan dengan anak-anak, paju sebagai bagian klimaks berpasangan dengan dewasa, dan seblang-seblang sebagai babak penutup berpasangan dengan tua. Masa anak-anak adalah masa meniru (imitatif), setiap gerakan dan ucapan orang lain ditirukan. Masa dewasa adalah masa pencarian identitas diri dan saling mempengaruhi (simpatetis), ada saatnya
Rina Martiara dan Arie Yulia Wijaya (Tari Gandrung Terob Sebagai Identitas Kultural Masyarakat Using Banyuwangi)

saling menyentuh (kontagius) antara Gandrung dan ретаju merupakan unsur dari kesuburan. Urutan periode, lahir-hidu-mati, dianggap juga melambangkan akhir dari tujuan setiap manusia.

\section{Penutup}

Nalar manusia (humand mind) masyarakat Using Banyuwangi yang pertama adalah, menganut struktur patriarki yaitu garis keturunan dari pihak laki-laki, oleh karena itu laki-laki dalam masyarakat Using di Banyuwangi memiliki peran yang penting yaitu, peran memimpin dan mencukupi kebutuhan rumah tangga dan peran dalam kehidupan sosial bermasyarakat. Kedua, masyarakat Using di Banyuwangi meskipun mayoritas beragama Islam namun tetap menghargai keberadaan para leluhur dan berperan dalam pelestarian seni budaya daerah. Ketiga, masyarakat Using di Banyuwangi kebanyakan adalah bertani, hal ini dibuktikan dengan penghargaan yang tinggi terhadap keberadaan Dewi Sri atau Dewi Kesuburan. Keempat, posisi liminal penari Gandrung Terob di atas justru menunjukkan bahwa penari Gandrung berada dalam posisi yang sangat penting yaitu, posisi di tengah, sebuah posisi yang menyatukan, menyelaraskan, menjaga kesinambungan, dan menyeimbangkan kehidupan masyarakat Using di Banyuwangi. Posisi di tengah, di pusat, adalah sebuah posisi yang tenang, diam, hening, dan juga abadi (Ahimsa-Putra, 2001:304).

\section{DAFTAR RUJUKAN}

Ahimsa-Putra, Heddy Shri (2000), Strukturalisme Levi-Strauss Mitos dan Karya Sastra, Galang Press, Yogyakarta.

Lévi-Strauss, Claude (2009), Antropologi Struktural, terj. Ninik Rochani Sjams, Kreasi Wacana, Yogyakarta.

Toer, Pramodya Ananta (2000), Mangir, Kepustakaan Populer Gramedia, Jakarta.

Winangun, Wartaya Y.W., 1990, Masyarakat Bebas Struktur, Liminalitas dan Komunitas Menurut Victor Turner, Kanisius, Yogyakarta. 


\title{
SISTEM TRANSMISI \\ WAYANG WONG GAYA YOGYAKARTA: STUDI KASUS KARAKTERISTIK POCAPAN
}

\author{
Oleh: Sarjiwo \\ Jurusan Seni Tari Fakultas Seni Pertunjukan ISI Yogyakarta. \\ Telp. 02748337 889/0815 7888 7707. Email: sarjiwo_tari@yahoo.co.id
}

\begin{abstract}
ABSTRAK
Penelitian ini bertujuan untuk mengungkapkan sistem transmisi Wayang Wong Gaya Yogyakarta: Studi kasus karakteristik pocapan. Teknik pengumpulan data yang digunakan adalah observasi, wawancara dan studi dokumentasi. Observasi dilakukan dengan melihat serta mengikuti aktivitas latihan dan pementasan yang dilakukan di sanggar-sanggar atau paguyuban, wawancara dilakukan secara terstruktur dengan panduan pedoman wawancara yang sudah dipersiapkan agar proses penjaringan data dapat lebih terfokus dan terarah, dan studi dokumentasi dilakukan dengan melihat hasil rekaman pementasan Wayang Wong Gaya Yogyakarta. Data yang berhasil dikumpulkan dianalisis dengan teknik analisis deskriptif kualitatif.

Hasil penelitian menunjukkan bahwa, sistem transmisi pocapan Wayang Wong Gaya Yogyakarta terjadi dalam dua sistem. Pertama dari sisi para penari atau pelaku generasi sebelumnya dan dari sisi generasi berikutnya. Sementara karakteristik di dalam Wayang Wong Gaya Yogyakarta dapat didapat pada karakter suara, nada suara, irama pocapan, dan kemampuan pengaturan volume suara. Karakter suara di dalam Wayang Wong Gaya Yogyakarta tidak dapat lepas dari karakter yang ada dalam Wayang Kulit Purwa, karena pada dasarnya wayang wong merupakan personifikasi dari wayang kulit purwa. Nada suara setiap pemeran harus memperhatikan suasana gamelan yang diatur dalam pathet yang sedang berlangsung. Irama pocapan sangat berkaitan dengan karakter tokoh dalam pewayangan yang merujuk pada lagak, lagu, lageane.
\end{abstract}

Kata kunci: Sistem transmisi, Wayang Wong, karakteristik pocapan.

\section{ABSTRACK}

This research purpose was to lay open the transmission system of Yogyakarta Style of Wayang Wong: Case study was characteristic of pocapan (dialogue). Data collecting techniques that used are by observation, interview and documentation study. Observation done not only by seeing and doing the practice of activity but also by staging that done in gallery and society, interview done structurally with the interview guidelines that prepared before so the data network process can be more focused and directional, and documentation study done by watched the staging record of Yogyakarta Style of Wayang Wong. After that, collected data analyzed done with qualitative description analyze technique.

Result research indicated that, pocapan (dialogue) transmission system of Yogyakarta Style of Wayang Wong happened in two systems. The first is come from dancers or previous generation side and the second was come from next generation side. For a while, in the characteristic of Yogyakarta Style of Wayang Wong there are voice characteristic, voice tone, rhythm of pocapan and the ability of voice volume control. Voice characteristic that appear in the Yogyakarta Style of Wayang Wong in not far away from the existing of characteristic in the Purwa Shadow Play, because basically Wayang Wong was Purwa Shadow Play characterization. Every character voice tone must to pay their attention to the atmosphere of gamelan that arranged in the happening pathet. Pocapan rhythm has a very close relation with the figure character in the Puppet, which was refers to lagak, lagu, lageane.

Key words: Transmission system, Wayang Wong, pocapan characteristic 


\section{Pendahuluan}

Melihat dan mengikuti dari beberapa pementasan Wayang Wong Gaya Yogyakarta yang dilaksanakan di beberapa tempat yang berbeda yaitu di Pendhapa nDalem Yudaningratan (ruang pentas yang secara tradisi sebagai tempat pentas Wayang Wong Yogyakarta), Monumen Serangan Umum 1 Maret di jalan Malioboro (ruang publik yang lebih terbuka), dan di gedung Societet Taman Budaya Yogyakarta (ruang pentas dalam gedung tertutup), dalam hal teknik tari pada umumnya penari telah mampu menunjukkan kemampuan kepenariannya secara baik. Sebagian besar penari dari kalangan generasi muda yang sangat potensial berkembang. Namun demikian, yang perlu mendapat perhatian adalah kemampuan pocapan atau dialog bagi penari masih belum menampakkan hasil yang optimal. Hal ini dilandasi oleh komentar beberapa penonton yang menyaksikan pergelaran tersebut yang mengatakan bahwa pocapan terdengar lamatlamat, tidak jelas, dialog perlu bantuan clip on, pocapan ora cetha yang kesemuanya tersebut menandakan adanya pocapan yang tidak sampai ke telinga penonton dengan baik. Sementara kejelasan pocapan yang mampu didengar penonton, akan berakibat pada jalinan cerita dan informasi yang disampaikan pemeran dapat diikuti oleh penonton. Padahal dimensi pokok dalam Wayang Wong adalah aspek gerak dan aspek pocapan atau dialog. Keduanya harus menjadi bagian yang harus dikuasai oleh penari agar karakter yang dimainkan menjadi utuh sesuai tuntutan peran yang dibawakan.

Kekurangan dalam hal kemampuan pocapan atau dialog semestinya tidak terjadi apabila sistem transmisi terhadap karakteristik pocapan Wayang Wong Gaya Yogyakarta berlangsung dengan baik. Dengan demikian, adanya kontinyuitas latihan akan berakibat pada kualitas pocapan akan meningkat lebih baik. Sebab kemampuan pocapan diperlukan untuk memperkuat karakter yang diperankan. Dengan demikian, terjadi transformasi karakter secara utuh. Seorang penari menurut para guru tari di Kraton Yogyakarta adalah, seseorang dianggap sudah "njoged" (menari) apabila dia menari dengan penuh disiplin, konsentrasi, motivasi dan dedikasi. Mereka punya idiom yang berlaku terhadap seorang penari yang belum terisi jiwanya dengan istilah "isa njoged nanging durung ngerti joged" sehingga belum mampu melihat nuansa antara "anjoged" (menari) dan "jogedan" (menari-nari). (Fred Wibowo, 1981: 105-107). Pernyataan ini dapat dimaknai sebagai satu kesatuan yang utuh di dalam memerankan tokoh. Pocapan atau dialog merupakan hal pokok dalam penyajian Wayang Wong Gaya Yogyakarta. Oleh karena itu setiap pemeran harus menempatkan pocapan sebagai bagian yang tak terpisahkan dari diri pemeran. Namun demikian, penguasan pocapan masih belum dapat dikuasai dengan baik oleh sebagian besar pemeran. Indikator belum dikuasainya pocapan dalam Wayang Wong Gaya Yogyakarta adalah, karena pocapan atau dialog yang diucapkan para pemeran belum mampu tersampaikan ke penonton dengan baik. Beberapa permasalahan yang terjadi dapat diidentifikasi antara lain: Pocapan untuk pemeran putri luruh tidak terdengar oleh penonton, Pocapan pada pemeran tokoh alusan luruh dengan nada rendah tidak terdengar oleh penonton, Pemeran tokoh alusan lanyap dengan nada tinggi dapat terdengar dari arah penonton, akan tetapi tidak jelas suku kata dan kalimat yang diucapkan, Pemeraran putra gagah walaupun volume suara dapat keras, akan tetapi artikulasi dan kejelasan suku kata mapun kalimat yang diucapkan tidak jelas, Pemeran yang menggunakan topeng tidak jelas pocapan yang diucapkan, Pemahaman dan penguasaan pocapan dalam karakter masih kurang, Penguasaan nada suara belum dikuasai dengan baik, Karakter suara belum dikuasai dengan baik.

\section{Metode Penelitian}

\section{A. Tempat dan Waktu Penelitian}

Penelitian ini bertempat di yayasan dan paguyuban tari di wilayah Yogyakarta yang masih melestarikan Wayang Wong Gaya Yogyakarta. Yayasan dan paguyuban tersebut adalah Krida Beksa Wirama Yogyakarta, Paguyuban Kesenian Irama Citra 
Yogyakarta, Yayasan Siswa Among Beksa Yogyakarta, Yayasan Pamulangan Beksa Sasminta Mardawa Yogyakarta, dan Perkumpulan Kesenian Surya Kencana Yogyakarta. Kelima yayasan dan perkumpulan tersebut selama ini berkiprah pada pembelajaran Tari Klasik Gaya Yogyakarta khususnya serta masih melestarikan Wayang Wong Gaya Yogyakarta.

Waktu penelitian dilaksanakan mulai bulan April-Nopember 2009. Secara kebetulan pada tanggal 12, 13, 14 Nopember 2009 dilaksanakan Festival Wayang Wong Gaya Yogyakarta untuk yang ketiga kalinya. Penulis sebagai salah satu panitia (salah satu nara sumber) sangat berkepentingan untuk mengikuti berbagai proses yang dilaksanakan. Walaupun proses penelitian dilakukan mulai bulan April 2009 dengan melakukan studi pustaka, observasi dan wawancara dengan para informan biasa dan informan terpilih (key informant), akan tetapi proses latihan dan pementasan pada saat festival menjadi bagian dalam melengkapi data agar mempunyai validitas yang tinggi. Dari peristiwa festival tersebut akan banyak data yang sangat dibutuhkan dalam kelengkapan laporan.

\section{B. Penentuan Informan}

Informan dalam penelitian ini terdiri dari informan terpilih (key informant) dan informan biasa yang merupakan bagian dari komunitas. Informan terpilih (key informant) terdiri dari para empu tari tari klasik Gaya Yogyakarta, pimpinan yayasan dan perkumpulan serta Dalang Wayang Kulit Purwa. Sementara informan biasa terdiri dari sutradara, penulis naskah wayang, guru tari klasik, pemerhati wayang dan para penari atau pelaku yang sering menjadi peran dalam pergelaran Wayang Wong Gaya Yogyakarta. Pemilihan dan penentuan informan dilakukan dengan proses penjajakan terlebih dahulu agar tidak terjadi kekeliruan dalam memilih informan.

\section{Pendekatan Penelitian}

Penelitian ini menggunakan pendekatan kualitatif. Peneliti berusaha untuk mengungkap berbagai fenomena dan permasalahan sistem transmisi serta karakteristik pocapan Wayang Wong Gaya Yogyakarta secara alami dan mendalam. Permasalahan tersebut mulai dari sistem transmisi, karakteristik pocapan yang meliputi karakter suara, nada suara, irama pocapan, volume suara dalam pemeranan Wayang Wong Gaya Yogyakarta.

\section{Teknik Pengumpulan Data}

Teknik pengumpulan data yang digunakan dalam penelitian ini menggunkan beberapa cara agar data yang dapat diperoleh dapat mengungkap permasalahan dari tujuan penelitian. Teknik pengumpulan data yang digunakan adalah wawancara, studi dokumen dan pengamatan (observasi). Wawancara adalah metode untuk mendapatkan data melalui tanya jawab langsung dan tatap muka langsung antara peneliti dengan informan. Di dalam wawancara, pewawancara/peneliti mempunyai peran penting agar mampu mendapatkan berbagai informasi (data) yang sesuai dengan tujuan penelitian. Oleh karena itu sebelum mengadakan wawancara pewawancara/peneliti perlu melakukan persiapan antara lain; menentukan responden, menyiapknan dan menyusun daftar pertanyaan, menyiapkan berbagai peralatan yang diperlukan misalnya buku catatan, alat tulis, alat perekam dan sebagainya. Teknik wawancara dilakukan dengan wawancara terstruktur dan wawancara tidak terstruktur. Wawancara terstruktur pewawancara/peneliti telah menyiapkan daftar pertanyaan yang telah dipersiapkan sebelumnya. Sedangkan wawancara tidak terstruktur yaitu wawancara dilakukan dengan tidak menyiapkan daftar pertanyaan. Di dalam penelitian ini peneliti menerapkan kedua teknik wawancara tersebut agar data penelitian dapat saling melengkapi. Pelaksanaan wawancara dilakukan dalam situasi 
JOGED

ISSN: $1858-3989$ serileks mungkin agar berbagai informasi dapat terjaring lebih alami. Untuk pelaksanaa wawancara dengan key informan atau informan terpilih dipergunakan alat perekam, sementara wawancara yang ditujukan pada responden spontan informasi hasil wawancara disalin ke dalam buku catatan.

Studi dokumen dalam penelitian ini dilakukan dengan melihat beberapa rekaman audio visual tentang pementasan Wayang Wong Gaya Yogyakrta. Hal ini dilakukan untuk memahami serta mendalami tentang karakter pocapan Wayang Wong Gaya Yogyakarta yang mempunyai kekhasan tersendiri. Dari rekaman audio visual tersebut akan diperoleh gambaran tentang implementasi pocapan dalam unjuk kerja yang sesungguhnya yang diujudkan dalam pementasan. Studi dokumen ini akan melengkapi di dalam analisis pocapan yang telah dipraktekkan oleh para pelaku/pemeran Wayang Wong Gaya Yogyakarta.

Observasi dilakukan dengan melihat aktivitas latihan serta pertunjukan yang dilaksanakan. Observasi dilakukan dengan mendatangi tempat-tempat pelaksanaan latihan dan pementasan dengan mencatat gejalagejala yang tampak pada objek penelitian. Oleh karena peneliti merupakan salah sorang pelaku yang sering berperan dalam pementasan wayang wong, maka peneliti dapat lebih membaur dalam lingkungan objek penelitian. Dengan demikian, data yang terkumpul dapat lebih alami dan sesuai dengan kebutuhan penelitian.

\section{E. Teknik Analisis Data}

Proses analisis data dalam penelitian kualitatif dilakukan bersamaan dengan proses pengumpulan data. Oleh karena itu setelah pengambilan data dari lapangan lalu mendeskripsikan data hasil wawancara dalam bentuk catatan lapangan, mengedit, mengklasifikasi untuk dijadikan bahan laporan penelitian. Data yang berhasil dikumpulkan dianalisis dengan teknik analisis deskriptif kualitatif. Untuk mendapatkan tingkat validitas yang tinggi dilakukan analisis triangulasi data diantara pada nara sumber dan para anggota. Sementara agar reliabilitas data terpenuhi dilakukan wawancara secara mendalam (indeph interview) di antara sumber apabila ada sesuatu yang kurang jelas serta untuk mengetahui tingkat keajegan (reliabilitas) jawaban.

\section{Hasil Penelitian dan Pembahasan}

\section{A. Sistem transmisi pocapan Wayang Wong Gaya Yogyakarta}

Sistem transmisi pocapan Wayang Wong Gaya Yogyakarta terjadi dalam dua sistem.Pertama dari sisi para penari atau pelaku generasi sebelumnya dan dari sisi generasi berikutnya. Generasi sebelumnya adalah para penari atau pelaku yang lebih dahulu belajar dan melakukan tugas pemeranan dalam wayang wong. Sementara generasi berikutnya adalah para penari atau pelaku yang masih dalam proses belajar untuk melakukan tugas pemeranan maupun teknik pocapan dalam Wayang Wong Gaya Yogyakarta. Apabila sistem transmisi pocapan Wayang Wong Gaya Yogyakarta ditinjau dari para pelaku generasi sebelumnya, dapat terjadi karena adanya kegiatan latihan untuk mempersiapkan sebuah pergelaran wayang wong. Secara alami proses transmisi pocapan terjadi pada saat pemaos kandha atau pembaca narasi menuntun pocapan bagi para pemeran dalam suatu adegan. Pada saat proses latihan pemaos kandha atau pembaca narasi akan menuntun kata atau kalimat pocapan yang tertulis pada naskah kepada penari atau pemeran. Selanjutnya penari atau pemeran akan menirukan kata atau kalimat pocapan sebagaimana yang diucapkan oleh pemaos kandha. Peniruan ini dilakukan penari atau pemeran persis sama sebagaimana yang diucapkan pemaos kandha. Baik diksi, intonasi, nada suara, irama suara, karakter suara 
atau warna suara, panjang pendeknya kata atau kalimat, seorang pemeran akan menirukan pocapan yang diucapkan oleh pemaos kandha sebagaimana adanya. Dengan demikian, sistem transmisi pocapan bagi pemeran generasi berikutnya bersifat transformatif. Pelaku atau penari tidak mempunyai kesempatan untuk bertanya, berinteraksi secara langsung dengan pemaos kandha apabila di dalam melakukan pemeranan masih kurang atau belum optimal di dalam membawakan perannya. Namun demikian tidak semua pemaos kandha melakukan proses yang demikian. Adanya pemaos kandha yang hanya membacakan teks pocapan tanpa disertai dengan karakter suara, nada suara dan irama suara yang didasarkan oleh karakter tokoh yang sedang diperankan menimbulkan kesulitan bagi para penari atau pemeran di dalam pocapan.

Apabila ditinjau dari sisi para penari atau pelaku generasi berikutnya, maka motivasi setiap individu di dalam peningkatan kualitas kepenarian atau pemeranan sangat berperan. Banyak ahli perpendapat bahwa motivasi dibedakan menjadi dua yaitu motivasi ekstrinsik dan motivasi intrinsik. Menurut Woolfolk dua demensi tersebut adalah:

...Motivation caused by external events or outside rewards that have nothing to do with the learning situation itself generaly is called extrinsik motivation. ... In contras to the behavioral view, the cognitive view emphasizes intrinsik (internal) sources of mativation, such as the satisfaction learning or accomplishment (Woolfolk, 1984 : 272-273).

Pendapat tersebut sejalan dengan pernyataan Oemar Hamalik bahwa pada pokoknya motivasi dibagi menjadi dua jenis yaitu motivasi instrinsik dan motivasi ekstrinsik. Motivasi instrinsik adalah motivasi yang hidup dalam diri, misalnya keinginan untuk mendapatkan ketrampilan tertentu, memperoleh informasi dan pengertian, mengembangkan sikap untuk berhasil, menyenangi kehidupan dan keinginan diterima oleh orang lain. Sementara motivasi ekstrinsik adalah motivasi yang disebabkan oleh faktor-faktor dari luar. (Oemar Hamalik, 2001: 2). Dalam hal motivasi intrinsik tersebut sangat tergantung pada diri individu di dalam meningkatkan diri, sementara motivasi ekstrinsik peran berbagai pengadaan aktivitas latihan ataupun pertunjukan wayang wong sangat membantu merangsang timbulnya motivasi ekstrinsik. Di dalam tari klasik Yogyakarta pada aspek penjiwaan yang dinamakan dengan Kawruh Joged Mataram yang diciptakan Sri Sultan Hamengkubuwono I (1755-1792), dapat dipahami sebagai motivasi intrinsik yang berasal dalam diri penari. Kawruh Joged Mataram (Ilmu Joged Mataram) ini terdiri dari 4 unsur yaitu: (1) Sawiji (konsentrasi), (2) Greged (semangat), (3) Sengguh (percaya diri), dan Ora mingkuh (pantang menyerah) (Fred Wibowo, ed., 1981: 90- 92). Untuk mencapai tataran kualitas kepenarian yang lebih baik sangat diperlukan Sawiji (konsentrasi) agar apa yang menjadi tujuan dan tuntutan setiap melakukan tugas pemeranan dapat dilakukan dengan baik. Oleh karena itu diperlukan Greget (semangat yang tinggi) agar peningkatan kualitas tersebut dapat setapak demi setapak meningkat. Selanjutnya Sengguh atau percaya diri merupakan sikap yang bertolak pada dorongan dari dirinya sendiri berupa hasrat dan keinginan untuk berhasil. Agar sesuatunya dapat berhasil diperlukan sikap Ora mingkuh atau pantang menyerah, adalah sebuah kinerja yang dilandasi oleh usaha yang terus menerus dan tidak takut menghadap kesukaran-kesukaran.

Bagi individu yang greteh atau suka bertanya, peningkatan kualitas kepenarian atau pemeranan dapat lebih cepat meningkat. Hal tersebut tampak pada seringnya mereka terlibat di dalam suatu pementasan tari klasik Gaya Yogyakarta khususnya. Keterlibatan ini secara alami akan memberi kontribusi terhadap peningkatan kualitas bagi 
JOGED

ISSN: $1858-3989$
Sarjiwo (Sistem Transmisi Wayang Wong Gaya Yogyakarta :

Studi Kasus Karakteristik Pocapan) mereka yang terlibat. Seringnya terlibat dalam pertunjukan tari tersebut secara alami maka frekuensi latihan akan semakin sering dilakukan. Seringnya melakukan latihan maka proses adaptasi otot untuk melakukan berbagai macam gerak akan lebih fleksibel. Demikian juga keterlibatan pertunjukan yang menggunakan dialog, maka kemampuan vokalpun akan dapat meningkat pula. Dengan demikian, proses adaptasi diri terhadap berbagai gaya tari di luar tradisinya akan semakin cepat dalam proses adaptasi.

Usaha yang dilakukan para penari atau pelaku generasi berikutnya untuk meningkatkan diri dilakukan dengan berlatih di luar dari latihan yang dilakukan paguyuban. Bagi mereka yang mempunyai motivasi tinggi untuk meningkatkan diri dengan melakukan latihan secara mandiri. Untuk latihan vokal dan pocapan mereka melakukan latihan di tempat-tempat terbuka misalnya di pantai, tepi sungai, grojogan (air terjun) bahkan di makampun dilakukan. Di samping itu latihan yang dilakukan tidak semata-mata untuk persiapan menjelang pentas saja, akan tetapi mereka berlatih sendiri dengan menirukan beberapa tokoh senior dalam berbagai peran dan karakter yang berbeda. Sebagaimana banyak diketahui bahwa para tokoh atau empu terdahulu mempunyai spesifikasi dalam memerankan tokoh dalam pewayangan. Oleh karena itu beberapa tokoh atau empu yang mempunyai spesifikasi dalam peran-peran tertentu tersebut perilakunya kadang berpengaruh dalam kehidupan sehari-hari. Bagi penari generasi berikutnya hal tersebut dapat menjadi nara sumber di dalam mendalami tokohtokoh tertentu dalam pewayangan. Dengan demikian, motivasi instrinsik dapat menghasilkan kualitas kepenarian dan pocapan yang lebih baik. Hal ini disebabkan bahwa latihan secara mandiri tidak dibatasi oleh ruang maupun waktu. Dimanapun dan kapanpun mereka menginginkan latihan dapat dilakukan tanpa dibingkai oleh karakter tertentu.

\section{B. Karakter dalam Wayang Kulit Purwa Gaya Yogyakarta}

Menurut Mas Lurah Cermosutejo seorang dhalang wayang kulit dan abdi dalem Kraton Yogyakarta, perbedaan karakter di dalam wayang kulit dapat diketahui pada wanda wayang. Pengertian wanda pada wayang kulit adalah gambaran air muka atau pasemon suatu tokoh yang merupakan perwujudan yang kasat mata dari suasana hati tokoh tersebut, misalnya keadaan tenang, keadaan marah atau sedang dimabuk asmara (Soedarso, 1986: 61). Karakter atau watak sebagian besar terwujud dalam bentuk raut muka, yaitu dalam bentuk sikap dan warnanya. Perwujudan watak dasar dilukiskan dalam pola bentuk dan warna raut muka atau wajah; yaitu pada pola, bentuk mata, bentuk hidung, bentuk mulut, warna muka, posisi muka dan posisi dan perbandingan tubuh (Soekanto, 1992: 23). Berdasar dari karakter tersebut akan mendasari di dalam karakter suara dari masing-masing tokoh. Menurut Mas Lurah Cermosutejo ada tiga karakter suara dalam wayang kulit yaitu luruh, magak, lanyap. Untuk karakter suara luruhpun ada luruh tanggung seperti Puntodewa, Abimanyau, Irawan, Sumitra dan Bambangan lainnya. Sementara untuk luruh mardawa seperti Janaka, Rama dan Lesmana. Untuk suara magak adalah karakter suara diantara karakter suara alus dan katakter suara lanyap seperti tokoh Karno, Dewabrata, untuk suara lanyap suara terkesan nyengka atau bersuara seperti dipaksakan, nyentak, emosi masuk dalam titi laras barang cilik (Wawancara, tanggal 25 Agustus 2009). Sejalan dengan penggolongan dalam tiga karakter tersebut di atas, Soekanto juga membagi dalam tiga posisi muka dalam wayang kulit purwa yaitu posisi luruh yang berarti menunduk ke bawah, posisi longok yang berarti memandang ke depan dan posisi langak agak menengadah, memandang agak ke atas. Luruh mempunyai karakter tenang, sabar, tak tergesa-gesa segala tindakannya. 
Kebalikannya adalah posisi langak, sementara longok mempunyai karakter antara luruh dan langak (Soekanto, 1992: $31)$.

\section{Karakter suara dalam Wayang Wong Gaya Yogyakarta}

Karakter suara di dalam Wayang Wong Gaya Yogyakarta tidak dapat lepas dari karakter yang ada dalam Wayang Kulit Purwa. Karena pada dasarnya Wayang Wong merupakan personifikasi dari wayang kulit. Di dalam wayang kulit purwa tipe karakter tokoh secara visual dapat dilihat pada bentuk muka wayang, wanda wayang dan bentuk tubuh wayang. Banyak macam bentuk tubuh yang ada pada wayang kulit purwa dengan karakter suara yang berbedabeda. Secara garis besar karakter suara dapat dikelompokkan menjadi swara weteng/padharan (suara perut), swara dhadha (suara dada), swara jangga/gulu/tenggak (suara leher) sampai swara metu (suara keluar yang berada pada rongga mulut). Ketiga karakter suara tersebut pada dasarnya merupakan karakter suara alami setiap manusia. Sifat suara alami manusia ini dalam keseharian dapat dijumpai pada saat kita berbicara yang bersifat rahasia akan menggunakan suara bisik-bisik yang mempunyai kecenderungan bernada rendah besar, hal demikian dihasilkan dari jangga andhap (leher bagian bawah), di dalam kebiasaan berbicara keseharian banyak menggunakan jangga tengah (leher bagian tengah) dan untuk marah, teriak, nyentak terdapat pada jangga inggil (leher bagian atas) yang bernada tinggi (barang cilik). Swara weteng/padharan (suara perut) akan menghasilkan suara yang berat, besar dan terkesan menahan, swara dhadha untuk suara yang besar, anteb dan untuk mbengok (teriak), swara jangga sampai swara metu untuk suara sedang sampai tinggi dalam tokoh alus lanyapan.

\section{Nada suara dalam Wayang Wong Gaya Yogyakarta}

Nada mengandung unsur-unsur tinggi rendahnya suara atau bunyi. Besar kecilnya suara adalah kodrat lahiriah, tetapi nada suara dapat dirubah dengan latihan secara teratur serta adanya kesadaran untuk membentuk pribadi dari pribadi orang itu sendiri (Djoddy, Tt. 22). Nada suara diperlukan agar pocapan atau dialog tidak monoton sehingga terjadi dinamika dalam pocapan. Nada suara setiap pemeran harus memperhatikan suasana gamelan yang diatur dalam pathet yang sedang berlangsung. Dengan kata lain, nada suara penari kawengku ing pathet atau dibingkai oleh pathet. Menurut RMT Djojodipura pathet adalah tempat duduk gending. Sementara Jakub dan Wignyarumeksa menyatakan "Pathet kuwi kanggo nglungguhake gendhing" (Yudoyono, 1984: 53). Oleh karena pergelaran wayang wong menggunakan iringan gamelan yang didasarkan oleh penyajian wayang kulit, maka urutan pathet adalah (1) Slendro pathet 6, Pelog pathet 5, (2) Slendro pathet 9, Pelog pathet 5, (3) Slendro pathet Manyura, Pelog pathet Barang (Yudoyono, 1984: 54). Masing-masing pathet tersebut membawa suasana atau atmosfir nada yang berbeda tinggi rendahnya. Misalnya sama-sama nada dasar suara enam dalam Laras Slendro pathet enem atau Pelog pathet lima, akan berbeda ketinggiannya apabila berada pada Laras Slendro pathet sanga atau Pelog pathet enem, dan akan jauh berbeda lagi dalam suasana Slendro pathet Manyura atau Pelog pathet Barang. Oleh karena itu setiap penari atau pemeran dalam Wayang Wong Gaya Yogyakarta harus dapat beradaptasi dengan suasana gending yang mengiringinya. Apabila tidak, maka pocapan yang disampaikan terasa hambar dan tidak sesuai dengan tinggi rendahnya laras gamelan.

1. Nada suara bagi peran putri

Pada umumnya seorang wanita mempunyai nada suara tinggi. Dasar 
suara ini tidak jauh berbeda dengan nada suara untuk peran-peran putri dalam Wayang Wong Yogyakarta. Untuk peran putri dapat menggunakan nada dasar barang, satu dan jangga alit atau dua tinggi. Nada dasar inipun tidak selalu mengikat apabila beberapa peran putri berada pada satu adegan yang secara bersamaan dengan nada dasar sama. Untuk itu seorang pemeran putri yang melakukan pocapan yang pertama kali, akan dijadikan dasar untuk pocapan peran putri yang lain. Oleh karena itu bagi pemeran putri yang melakukan pocapan pertama kali harus tahu betul nada dasar yang harus dipakai untuk mengawali pocapan. Misalnya pada adegan yang sama ada peran Dewi Wara Sembadra, Larasati dan Dewi Srikandi, maka pada saat Dewi Wara Sembadra yang melakukan pocapan pertama kali nada dasarnya harus lebih rendah daripada Larasati atau Dewi Wara Srikandi. Sebab apabila nada dasarnya menggunakan nada dasar terlampu tinggi kemungkinan Larasati atau Dewi Wara Srikandi tidak akan dapat lebih tinggi dari nada yang digunakan Dewi Wara Sembadra. Demikian juga apabila Dewi Wara Srikandi melakukan pocapan yang pertama kali, maka nada dasar untuk pocapan tidak boleh lebih rendah dari Dewi Wara Sembadra. Aturan pengambilan nada dasar untuk peran-peran putri berada pada nada dasar barang atau bem untuk putri luruh dan untuk karakter putri branyak pada jangga alit atau dua tinggi. Ini semua tergantung dari karakter yang dimainkan, nada suara patokannya pada ambah-ambahan gamelan yang mengiringinya pada saat pocapan berlangsung.

Tabel: 1

Nada suara peran putri

\begin{tabular}{|l|l|l|l||}
\hline \hline No & Karakter tokoh & Contoh tokoh & Nada suara \\
\hline \hline 1 & Luruh & $\begin{array}{l}\text { Dewi Wara Sembadra, Dewi } \\
\text { Sinta, Larasati, }\end{array}$ & $\begin{array}{l}\text { Barang alit atau } \\
\text { bem }\end{array}$ \\
\hline 2 & Lanyap atau Branyak & Wara Srikandi & Jangga alit \\
\hline \hline
\end{tabular}

2. Nada suara bagi peran putra alus

Nada suara untuk karakter alus dibedakan menjadi dua yaitu putra alus luruh dan putra alus mbranyak atau lanyap. Untuk putra alus luruh menggunakan nada dasar lima atau enem ageng. sementara untuk nada dasar mbranyak dapat menggunakan nada dasar enem atau barang alit untuk tokoh yang di dalam wayang kulitnya tergolong dalam karakter muka longok, untuk tokoh yang tergolong dalam karakter langak dapat menggunakan barang alit dan loro inggil. Namun demikian apabila dalam suatu adegan terdapat beberapa tokoh dengan karakter yang sama, maka pemeran harus memperhatikan karakter tokoh dalam pewayangan. Artinya nada suara dapat disesuaikan dengan situasi atau suasana hati tokoh sedang dalam kondisi apa. Permasalahan ini sering tidak dipahami oleh para pemeran. Proses adaptasi tersebut diperlukan agar diantara tokoh dengan nada dasar (titi laras) yang sama, dapat menyesuaikan kembali dengan menurunkan atau menaikkan nada yang disesuaikan dengan karakter tokoh. Misalnya dalam suatu adegan secara bersamaan terdapat peran Janaka, Putadewa dan Abimanyu, maka nada suara ketiganya harus disesuaikan kembali dengan situasi yang terjadi. Karena pocapan ketiga tokoh tersebut tinggi rendahnya 
nada dasar yang digunakan berbeda antara wayang kulit dan wayang wong. Di dalam wayang kulit Janaka lebih rendah dengan nada dasar lima atau enem ageng lebih rendah dari Puntadewa atau Abimanya. Akan tetapi di dalam
Wayang Wong Gaya Yogyakarta Janaka menggunakan nada dasar lebih tinggi dari Abimanyu disebabkan karakter Janaka yang mempunyai sifat ada kongasnya dan sifat pocapan yang romantis.

Tabel: 2

Nada Suara Peran Putra Alus

\begin{tabular}{|c|c|c|c|}
\hline No & Karakter tokoh & Contoh tokoh & Nada suara \\
\hline 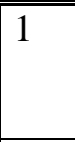 & Alus luruh & $\begin{array}{ll}\text { Arjuna, } & \text { Rama, } \\
\text { Lesmana, } & \\
\text { Angkawijaya } & \\
\end{array}$ & $\begin{array}{l}\text { Lima, atau enem } \\
\text { ageng }\end{array}$ \\
\hline \multirow[t]{2}{*}{2} & \multirow[t]{2}{*}{ Alus Lanyap atau branyak } & $\begin{array}{l}\text { Nakula, Sadewa, } \\
\text { Wibisana, Prabu } \\
\text { Jungkung Mardeya, } \\
\text { Prabu Sri Suwela } \\
\text { dan Para Raja } \\
\text { Alusan yang berada } \\
\text { di pihak yang kalah }\end{array}$ & $\begin{array}{l}\text { Barang alit atau } \\
\text { loro inggil }\end{array}$ \\
\hline & & Samba, Wisanggeni & Loro inggil \\
\hline
\end{tabular}

3. Nada suara bagi peran putra gagah

Nada suara di dalam peran putra gagah dapat dilihat dan dibedakan oleh ragam tari yang digunakan. Untuk penggunaan ragam tari gagah Kambeng lebih besar dari yang menggunakan ragam tari Kalangkinantang. Di dalam ragam Kalangkinantangpun tidak semua tokoh mempunyai nada dasar yang sama tergantung dari karakternya. Untuk Werkudara misalnya dapat menggunakan nada dasar dhadha ageng, lima ageng atau enem ageng tergantung dari kemampuan suaranya, lebih tegas, nugel atau getas, Gatutkaca dengan nada dasar enem ageng, dan untuk peran-peran dengan ragam Kalangkinantang menggunakan nada dasar jangga atau enem, yang tinggi rendahnya disesuaikan dengan karakter pada wayang kulitnya. Prinsipnya harus menguasai swara weteng (perut) untuk jenis suara yang berat dan besar, swara dhadha (dada) untuk menghasilkan swara angglung (suara yang menggema) yang biasa digunakan untuk karakter gagah dan swara jangga (leher) untuk menghasilkan suara kecil (Wawancara dengan KRT Pujaningrat, 25 Agustus 2009). Misalnya untuk Gatutkaca menggunakan suara dari swara dhadha, untuk raksasa menggunakan suara dari swara weteng, Dasamuka lebih berat atau mambeg yang berada pada swara weteng sampai swara dhadha, Setija berat dan magak dari swara dhadha karena mempunyai karakter setengah Kambeng disebabkan dalam wayang kulitnya bermata thelengan, Prabu Baladewa dari swara jangga sampai pada swara metu tidak berat. Hal yang tidak boleh dilupakan adalah, bahwa pocapan harus jelas, keras, anteb dan manteb, suku katanya tidak tertelan dan tidak ada yang hilang. Untuk keperluan itu sering dijumpai pada saat membaca dan menyuarakan huruf a disuarakan jadi ha, d disuarakan jadi dha, $\mathrm{k}$ disuarakan jadi g, misalnya 
"Prajurit sapa aranmu, maju sura ngadilaga" akan disuarakan menjadi
"Prajurit sapha haranmu, maju sura ngadilaga" dan sebagainya.

Tabel: 3

Nada suara peran putra Gagah

\begin{tabular}{||l|l|l|l|}
\hline No & Karakter Tokoh & Contoh Tokoh & Nada Suara \\
\hline \hline 1 & Gagah Kambeng & Werkudara, & $\begin{array}{l}\text { Telu,lima atau } \\
\text { enem ageng }\end{array}$ \\
\hline 2 & Gagah Kinantang & Setija & Jangga \\
\hline 3 & Gagah Bapang & Dursasana, Burisrawa & Jangga \\
\hline 4 & Gagah Impur & Duryudana & Enem ageng \\
\hline
\end{tabular}

4. Irama pocapan dalam Wayang Wong Gaya Yogyakarta

Irama pocapan adalah cepat lambatnya pocapan yang diucapkan oleh setiap pemeran menurut karakter tokoh pewayangan yang diperankan. Irama pocapan diperlukan agar di dalam pocapan tidak sekedar menyampaikan teks pocapan tanpa dilandasi oleh karakter tokoh, suasana serta makna teks pocapan. Terlebih lagi bahwa pocapan Wayang Wong Gaya Yogyakarta mempunyai gaya yang berbeda dengan antawecana Wayang Wong Gaya Surakarta maupun gaya pakeliran. Irama pocapan diperlukan agar pocapan menjadi tidak terkesan monoton. Kesan ini dapat muncul disebabkan oleh ketidakmampuan seorang penari/pemeran di dalam memahami karakter ataupun makna teks pocapan. Tidak jarang ditemukan seorang penari/pemeran pada saat pocapan seakan sedang membaca teks, padahal dia tidak sedang membaca teks. Hal ini terjadi karena penari/pemeran tidak mengatur cepat lambatnya pocapan yang didasarkan pada karakter atau suasana adegan.

5. Volume suara dalam pemeranan

Sebagaimana telah dijabarkan pada bab terdahulu bahwa banyak komentar dari para penonton yang mengatakan bahwa kemampuan pocapan atau dialog bagi penari masih belum menampakan hasil yang optimal. Sebagian besar penonton mengatakan bahwa volume suara dalam pocapan para pemeran terdengar lamat-lamat, tidak jelas, dialog perlu bantuan clip on, pocapan ora cetha yang kesemuanya tersebut menandakan adanya pocapan yang tidak sampai ke telinga penonton dengan baik Padahal pocapan yang mampu didengar penonton, akan berakibat pada jalinan cerita dan informasi yang disampaikan pemeran dapat diikuti oleh penonton. Hal tersebut dapat terjadi apabila kemampuan pemeran di dalam mengatur volume suara dapat jelas terdengar dari arah penonton. Tantangan bagi para pemeran dengan nada rendah untuk meningkatkan kemampuan vokalnya agar volume pocapan dapat lebih keras.

\section{Kesimpulan dan Saran}

\section{A. Sistem transmisi pocapan Wayang Wong Gaya Yogyakarta}

1. Sistem transmisi pocapan Wayang Wong Gaya Yogyakarta terjadi dalam dua sistem. Pertama dari sisi para penari atau pelaku generasi sebelumnya dan dari sisi generasi berikutnya. Secara alami proses transmisi pocapan terjadi pada saat pemaos kandha atau pembaca narasi menuntun pocapan bagi para pemeran dalam suatu adegan.

2. Apabila ditinjau dari sisi para penari atau pelaku generasi berikutnya, maka motivasi setiap individu di dalam peningkatan kualitas kepenarian atau pemeranan sangat berperan. Bagi mereka yang mempunyai motivasi tinggi untuk 
meningkatkan diri dengan melakukan latihan secara mandiri.

3. Karakteristik pocapan Wayang Wong Gaya Yogyakarta

\section{a. Karakter suara}

Karakter suara di dalam Wayang Wong Gaya Yogyakarta tidak dapat lepas dari karakter yang ada dalam Wayang Kulit Purwa. Karena pada dasarnya Wayang Wong merupakan personifikasi dari wayang kulit. Secara garis besar karakter suara dapat dikelompokkan menjadi swara weteng/padharan (suara perut), swara dhadha (suara dada), swara jangga/gulu/tenggak (suara leher) sampai swara metu (suara keluar yang berada pada rongga mulut). Ketiga karakter suara tersebut pada dasarnya merupakan karakter suara alami setiap manusia. Pemeran putri mempunyai karakter suara yang cenderung terletak pada tenggorokan bagian atas (swara jangga dan swara metu). Untuk karakter suara alus luruh menggunakan suara dari swara dhadha, untuk karakter suara alus branyak atau lanyapan menggunakan swara jangga/gulu/tenggak atau leher bagaian atas sampai pada swara metu. Sedangkan karakter suara untuk peran putra gagah secara garis besar dapat digolongkan dalam karakter suara berat dan besar, suara angglung atau menggema, untuk gagah magak, dan suara kecil melengking untuk raksasa seperti Cakil.

b. Nada suara

Nada suara setiap pemeran harus memperhatikan suasana gamelan yang diatur dalam pathet yang sedang berlangsung. Aturan pengambilan nada dasar untuk peran-peran putri berada pada nada dasar barang atau bem untuk putri luruh dan untuk karakter putri branyak pada jangga alit. Ini semua tergantung dari karakter yang dimainkan, nada suara patokannya pada ambahambahan gamelan yang mengiringinya pada saat pocapan berlangsung. Untuk putra alus luruh menggunakan nada dasar lima atau enem ageng sementara untuk nada dasar mbranyak dapat menggunakan nada dasar enem atau untuk tokoh yang di dalam wayang kulitnya tergolong dalam karakter muka longok, untuk tokoh yang tergolong dalam karakter langak dapat menggunakan barang alit dan loro inggil. Nada suara di dalam peran putra gagah dapat dilihat dan dibedakan oleh ragam tari yang digunakan. Untuk penggunaan ragam tari gagah Kambeng lebih besar dari yang menggunakan ragam tari Kalangkinantang.

Kalangkinantangpun tidak semua tokoh mempunyai nada dasar yang sama tergantung dari karakternya. Hal yang tidak boleh dilupakan adalah, bahwa pocapan harus jelas, keras, anteb dan manteb, suku katanya tidak tertelan dan tidak ada yang hilang.

c. Irama pocapan

Irama pocapan adalah cepat lambatnya pocapan yang diucapkan oleh setiap pemeran menurut karakter tokoh pewayangan yang diperankan. Irama pocapan sangat berkaitan dengan karakter tokoh dalam pewayangan yang merujuk pada lagak, lagu, lageane. Lagak adalah pembawaan atau sikap dari tokoh yang satu dengan lainnya berbeda, lagu 
adalah tinggi rendahnya intonasi suara diantara wayang satu dengan lainnya, dan lagean adalah watak atau karakter dan kebiasaan dari tokoh dalam wayang yang satu dengan lainnya berbeda.

\section{d. Volume suara}

Kemampuan terhadap volume suara dalam pocapan bagi para pemeran masih belum optimal, sebagian besar kalimat pocapan tidak sampai ke telinga penonton dengan baik Untuk keperluan itu kemampuan pemeran di dalam mengatur volume suara harus ditingkatkan agar kemampuan pocapan dapat jelas terdengar dari arah penonton. Terlebih lagi bagi para pemeran dengan nada rendah untuk meningkatkan kemampuan vokalnya agar volume pocapan dapat lebih keras.

\section{B. Saran}

1. Lembaga-lembaga yang berkompeten menyelenggarakan pertunjukan Wayang Wong Gaya Yogyakarta sebaiknya meningkatkan frekuensi pertunjukan Wayang Wong Gaya Yogyakarta agar sistem transmisi Wayang Wong Gaya Yogyakarta dapat terjadi.

2. Oleh karena terikat oleh karakter, untuk pocapan pemeran putri luruh kadang tidak terdengar oleh penonton. Oleh sebab itu para pemeran putri luruh harus membiasakan diri untuk berlatih vokal dengan volume yang keras.

3. Untuk pemeran tokoh alus luruh dengan nada rendah kadang pocapan tidak terdengar dari arah penonton. Oleh sebab itu sebagaiman pada pemeran putrid luruh, para pemeran putra alus luruh harus membiasakan diri untuk berlatih vokal dengan volume yang keras.
3. Pemeran tokoh alusan lanyap dengan nada tinggi dapat terdengar dari arah penonton, akan tetapi tidak jelas suku kata dan kalimat yang diucapkan. Oleh karena itu perlu banyak latihan vokal untuk memperjelas artikulasinya.

4. Pemeraran putra gagah kambeng dengan nada rendah harus banyak latihan vokal agar volume suara dapat keras, dan kejelasan suku kata maupun kalimat yang diucapkan dapat di dengar penonton.

5. Bagi pemeran yang menggunakan topeng harus beradaptasi dengan topeng yang dikenakan, dan banyak melakukan latihan mengoptimalkan kemampuan volume suara. Hal tersebut diperlukan karena pengaturan nafas kadang terganggu dengan adanya topeng yang dikenakan.

6. Oleh karena pemahaman dan penguasaan pocapan dalam karakter masih kurang, maka setiap pemeran harus banyak bertanya pada para guru atau dhalang agar transformasi karakter dapat luluh menyatu.

7. Adanya temuan bhwa tidak semua pemeran mengetahui titi laras atau nada suara bagi tokoh yang diperankan, maka setiap pemeran harus mengetahuinya. Hal tersebut diperlukan agar pada saat mengawali untuk pocapan, langsung dapat memasuki wilayah tranformasi karakter tokoh yang diperankan.

\section{DAFTAR RUJUKAN}

\section{B.P.A. Soerjadiningrat, 1934, Babad lan Mekaring Djoged Djawi. Kolf Buning, Jogjakarta.}

Dewan Ahli Yayasan Siswo Among Bekso, 1981, Kawruh Joged Mataram. Yayasan Siswo Among Bekso, Yogyakarta.

Djoddy, M., Tt, Mengenal Permainan Seni Drama. Arena Ilmu, Jakarta-Surabaya.

Hamzah, A. Adjib, 1985, Pengantar Bermain Drama. CV Rosda, Bandung. 
Hardjowirogo, 1982, Sejarah Wayang Purwo. PN Balai Pustaka, Jakarta.

Herman, J. Waluyo, 2001, Drama: Teori dan Pengajarannya. PT Hanindita Graha Widya, Yogyakarta.

Sumaatmadja, Nursid. 1998, Manusia dalam Kontek Sosisal, Budaya dan Lingkungan Hidup. CV Alvabeta, Bandung.

Rendra, 1982, Tentang Bermain Drama. PT. Dunia Pustaka Jaya, Jakarta.

Oemar Hamalik, 2003, Proses Belajar Mengajar. PT Bumi Akasara, Jakarta.

Samuel Soeitoe, 1982, Psikologi Pendidikan. Lembaga Penerbit Fakultas Ekonomi Universitas Indonesia, Jakarta.

Siagian, Sondang. P., 1995, Teori Motivasi dan Aplikasinya. PT. Rineka, Jakarta.

Slameto, 2003, Belajar dan Faktor-faktor yang Mempengaruhinya. PT Rineka Cipta, Jakarta.

Soedarso, SP., 1986, "Wanda Suatu Studi tentan Resep Pembuatan Wanda-wanda Wayang Kulit Purwo dan Hubungannya dengan Presentasi Realistik", (Laporan Penelitian), Proyek Penelitian dan pengkajian Kebudayaan Nusantara (Javanologi) Direktorat Jenderal Kebudayaan Depdikbud.

Soekatno, 1992, Mengenal Wayang Kulit PurwaAneka Ilmu, Semarang.

Suharto, Ben, 1991, "Tari dalam Pandangan Kebudayaan", dalam Jurnal SENI Edisi Perdana, BP. ISI, Yogyakarta.

Tjondroradono, Soenartomo, 1996, "Pengetahuan Tari Gaya Yogyakarta: Jenis dan Perwatakannya", (Diktat), Sekolah Menengah Karawitan Indonesia, Yogyakarta.

Wibowo, Fred. (Ed), 1981, Mengenal tari Klasik Gaya Yogyakarta. Dewan Kesenian Propinsi Daerah Istimewa Yogyakarta, Yogyakarta.

Woolfolk, Anita E. \& Nicolich, Lorraine McCune, 1984, Educational Psychology for Teacher,
Prentice Hall, Inc., Englewood Cliffs, New Jersey.

Yudoyono, Bambang, 1984, Gamelan Jawa: Awal Mula, Makna Masa Depannya. PT Karya Unipres, Jakarta.

\section{Nara Sumber:}

Drs. H. GBPH Yudaningrat, MM., Pengageng Kawedanan Hageng Kraton Yogyakarta.

Drs. Yudono, Penari dan Pembina Kesenian Tradisi Kabupaten Kulon Progo Yogyakarta

Kanjeng Raden Tumenggung Pujaningrat (RM Dinusatomo), Ketua Yayasan Siswo Among Bekso Yogyakarta.

Kanjeng Mas Tumenggung Widyowinoto, Guru SMK I Kasihan Bantul, abdi dalem Kraton Yogyakarta

Kenthus, Sutradara dan pemain Wayang Wong Gaya Surakarta anggota Sekar Budaya Nusantara Jakarta.

L. Danis Subroto, Penari Wayang Wong Gaya Yogyakarta.

Mas Lurah Cermosutejo, 53 tahun, Seorang dalang wayang kulit Gaya Yogyakarta, abdi dalem Kraton Yogyakarta.

RM. Ibnu Mutarto, Penari senior sesepuh Yayasan Pamulangan Beksa Sasminta Mardawa Yogyakarta.

RM. Krisyadi, Penari, Sutradara Wayang Wong Gaya Yogyakarta.

Siti Sutiyah Sasminta Mardawa, Ketua Yayasan Pamulangan Beksa Sasminta Mardawa.

Undung Wiyono, Penulis naskah Wayang Wong Gaya Surakarta di Sekar Budaya Nusantara Jakarta.

Widodo Pujobintoro, Guru SMK I Kasihan Bantul, Penari Wayang Wong Gaya Yogyakarta. 


\title{
WAYANG WONG \\ LANGEN LESTARI BUDOYO DONOMULYO SEBUAH KAJIAN GAYA WAYANG WONG PEDESAAN
}

\author{
Surojo \\ Jurusan Tari, Fak. Seni Pertunjukan ISI Yogyakarta
}

\begin{abstract}
Wayang wong Lestari Budaya Donomulyo who was born and developed in rural communities Donomulyo an individual and collective expression of the rural art style. This Wayang wong was founded in 1932 by $R$. Sanghadi as a palace of Yogyakarta Sultanate courtiers.This transformation and culture of palace formality was a cultural diffusion of the cultural center of the (palace) to a small cultural center (rural), thus giving birth to an art style that is different from the original. This diffusion certainly related to the role Kridha Beksa Wirama in 1918 as an arts institution devoted to the general public, including people from the countryside

The rural of wayang wong is a rustic contemporary art form of the distribution and development of the foregoing, where the elements that influence complex either in a linear kesejarahannya of Kridha Beksa Wirama and social culture. That is, in the process of formation of wayang wong arable quality, especially choreography has a unique claim as the expression of which is produced by the artist that is a blend of rustic palace of art with the art of rural tradition "ndeso". This traditional art is an art form that originates and stems as well have been perceived as belonging to the arts community. Hasil accepted as tradition, the inheritance devolved from the older to the younger generation.
\end{abstract}

Keyword : wayang wong, traditional, rural style, the diffusion

\begin{abstract}
ABSTRAK
Wayang wong Lestari Budaya Donomulyo yang lahir dan berkembang di komunitas masyarakat desa Donomulyo merupakan ekspresi individu dan kolektif sebagai gaya seni pedesaan. Wayang wong ini didirikan pada tahun 1932 oleh R. Sanghadi sebagai seorang abdi dalem keraton Kasultanan Yogyakarta. Transformasi dan formalitas budaya keraton ini adalah suatu difusi budaya dari pusat budaya besar (keraton) ke pusat budaya kecil (pedesaan), sehingga melahirkan suatu gaya seni yang berbeda dari aslinya. Persebaran ini tentu terkait dengan peran Kridha Beksa Wirama pada tahun 1918 sebagai lembaga kesenian yang disediakan untuk masyarakat umum, termasuk orang-ortang yang berasal dari pedesaan.

Wayang wong pedesaan adalah sebuah bentuk kesenian kontemporer dari hasil persebaran dan perkembangan sebelumnya, di mana unsur-unsur yang turut mempengaruhi sangat kompleks, terutama sejarah secara linier dari Kridha Beksa Wirama. Artinya, dalam proses pembentukan kualitas garapan wayang wong, terutama garapan koreografi memiliki keunikan sebagai ekspresi yang diproduksi oleh seniman pedesaan yakni perpaduan antara seni keraton dengan seni tradisi pedesaan yang "ndeso". Kesenian tradisional ini adalah bentuk seni yang bersumber dan berakar serta telah dirasakan sebagai milik masyarakat..Hasil kesenian diterima sebagai tradisi, yang pewarisannya dilimpahkan dari angkatan tua kepada angkatan muda.
\end{abstract}

Kata kunci : wayang wong, tradisi, gaya pedesaan, difusi

\section{Latar Belakang Masalah}

Keberadaan wayang wong Langen Budaya Donomulyo yang didirikan pada tahun 1932 sebenarnya tidak bisa lepas dari peran R. Sanghadi sebagai seorang guru dan abdi dalem keraton. Transformasi dan formalitas budaya istana ini mencerminkan kuatnya pengaruh budaya elit atau keraton terhadap budaya rakyat atau kecil. Seperti dikemukakan oleh Kuntowijoyo, bahwa dualisme 
budaya Jawa menempatkan budaya besar (elit) yang dikuasai kerajaan adalah sebagai pusat kreativitas yang sah, sehingga kebudayaan keraton memancarkan sinarnya ke kebudayaan desa. Sebaliknya, desa hanya diakui daerah pinggiran budaya dan kreativitasnya hanya dianggap sebagai karya yang belum selesai dan mentah. Perkembangan budaya tradisional hanya bersifat perkembangan sintagmatis, yaitu pluralisme budaya ditampakkan lebih dalam perbedaan variasi atau cengkok semata-mata dan tidak mengubah polanya (Kuntowijoyo, 1987: 24-25). Oleh karena itu, maka tidak mengherankan apabila muncullah gaya wayang wong pedesaan sebagai ekspresi kolektif mereka yang 'ndeso'. Peniruan genre wayang wong gaya Yogyakarta oleh seniman desa Donomulyo sebenarnya dilatarbelakangi oleh spirit komunal yang menganggap seni keraton sebagai seni keramat, sehingga kesadaran mereka sematamata ditujukan untuk menjaga kepentingan desa sebagai kesatuan sistem kenegaraan kerajaaan Kasultanan Yogyakarta dalam konteks keseimbangan mikrokosmos dan makrokosmos.

Transformasi dan formalitas budaya keraton ke dalam budaya rakyat pedesaan ini sesungguhnya merupakan bentuk difusi budaya yang dibawa oleh seorang abdi dalem keraton Kasultanan Yogyakarta yang bernama R. Sanghadi ke dalam lingkungan budaya pedesaan sebagai tempat tinggalnya. Menurut teori difusi, bahwa gejala persamaan unsur-unsur kebudayaan di berbagai tempat di dunia disebabkan karena persebaran atau difusi dari unsur-unsur itu ke tempat-tempat lain. Untuk melacak adanya kesamaan unsur-unsur, maka sebagian besar dari keterangannya akan diperolehnya dari para informan, dengan berbagai macam metode wawancara.

Rivers mengalami bahwa banyak bahan keterangan mengenasi kehidupan sesuatu masyarakat dapat dianalisis dari daftar-daftar asal-usul, atau genealogi, dari para informan itu. Dengan demikian seorang peneliti harus mengumpulkan sebanyakmungkin daftar asalusul individu-individu dalam masyarakat obyek penelitian penelitiannya itu. Dengan mengajukan pertanyaan-pertanyaan mengenai kaum kerabat dan nenek moyang para individu tadi sebagai pangkal, seorang peneliti dapat menembangkan (baca: mengembangkan) suatu wawancara yang luas sekali, mengenai bermacam-macam peristiwa yang menyangkut kaum kerabat dan nenek moyang tadi, dengan pertanyaan-pertanyaan yang bersifat konkret (Koentjaraningrat, 1987:118)

Pernyataan ini tampaknya dapat dipahami dalam konteks menelusuri sejarah perkembangan wayang wong Lestari Budaya Donomulyo, terutama melacak dari keturunan R. Sanghadi dan para kerabat atau para murid-muridnya yang dewasa ini sebagai pelestari wayang wong pedesaan itu. Keberadaan grup wayang wong Lestari Budaya ini merupakan bukti bahwa kesenian tradisi itu tumbuh dan berkembang sebagai warisan budaya nenek moyangnya.

Proses persebaran itu tentu diwarnai adanya dialektika budaya antara budaya besar (keraton) dengan budaya kecil (desa) sebagai proses pembentukan jatidiri budaya lokal. Secara umum dialektika berarti sebuah proses pelik konflik konseptual atau sosial, interkoneksi dan perubahan, terutama penciptaan, interpenetrasi, dan pertentangan yang menghasilkan mode pemikiran atau bentuk kehidupan yang cenderung memainkan peran penting (William Outhwaite,editor, 2008 :211). Proses tawar-menawar atau tarik-menarik merupakan bagian penting untuk mendapatkan format baru dalam bentuk kesenian, yang akhirnya diperoleh suatu kesepakatan atau persamaan persepsi terhadap gaya seni yang disajikan. Gaya wayang wong pedesaan ini dijadikan fokus kajian, sehingga diperoleh suatu gambaran menyeluruh tentang koreografi sebagai sintesis dari proses difusi budaya.

R. Sanghadi sebagai guru Kawula Kasultanan yang memiliki separangkat gamelan memberikan kesempatan kepada masyarakat Klangon, Sedayu dan Moyudan untuk melakukan kegiatan uyonuyon, sehingga kegiatan ini menjadi faktor penting perkembangan wayang wong gaya Yogyakarta di wilayah perbatasan antara D.I.Y. dengan Jawa Tengah. Di samping itu, status R. Sanghadi sebagai abdi dalem keraton Kasultanan Yogyakarta adalah faktor penentu tumbuh dan perkembangan genre wayang wong di Kabupaten Kulonprogo. Hal ini menunjukkan seni pertunjukan ini yang semula lahir, tumbuh dan berkembang di dalam keraton, kemudian berkembang dan tersebar di luar tembok keraton, sampai di pedesaan. Wayang wong di Yogyakarta berkembang dan mengalami persebaran sejak pemerintahan Hamengku Buwana I dengan lakon Gandawardaya sekitar akhir tahun 1750-an dan mencapai puncak kejayaan pada masa 


\section{JOGED}

ISSN: $1858-3989$

pemerintahan HB VIII (1921-1939) yang ketika itu memproduksi wayang wong untuk waktu berharihari (Soedarsono, 1990: 19 dan 29). Dengan demikian, perkembangan wayang wong gaya Yogyakarta di luar tembok keraton, tampaknya berada pada masa pemerintahan Sultan Hamengku Buwana VIII yang ketika itu R. Sanghadi sebagai abdi dalem keratoan.

Fenomena persebaran seni tradisi keraton sebenarnya sudah terjadi pada masa pemerintahan HB VII, tepatnya pada tahun 1918, atas restu Sultan di Yogyakarta berdiri sebuah lembaga kesenian bernama Kridha Beksa Wirama. Lembaga ini diprakarsai Pangeran Soerjodiningrat dan Pangeran Tejakusuma. Murid-murid KBW sebagian besar terdiri dari para pelajar Yogyakarta yang bergabung dalam Jong Java. Semenjak itu kesenian keraton termasuk wayang wong dapat dipelajari oleh masyarakat luas dan berkembang pesat, bahkan Krida Beksa Wirama pernah mementaskan wayang wong di Bandung yang diselenggarakan oleh Java Instituut pada tahun 1921 (Soedarsono, 1990: 29). Pertunjukan wayang wong gaya Yogyakarta ini kemungkinan memberi inspirasi seniman local untuk diadaptasi, meskipun di wilayah Priangan (Bandung) sebenarnya sudah berkembang wayang wong pada awal abad ke -20, sebab kesenian ini sangat digemari oleh khalayak umum, yang diduga merupakan awal lahirnya wayang wong gaya Priangan (Iyus Rusliana, 2002: 28). Pengaruh kebudataan Mataram terjadi pada masa pemerintahan Sultan Agung dan dilanjutkan pada masa pemerintahan Sunan Amangkurat I pada tahun 1645 yang ditandaio perkawinan antara Sunan Amangkurat I dengan cucu Panembahan Ratu Alit yang bernama Panembahan Girilaya (Ibid.,: 48). Persebaran budaya keraton Mataram dan Kasultanan Yogyakarta tampaknya sudah berlangsung sangat lama, termasuk pesrevaran wayang wong gaya Yogyakarta ke desa Dopnomulyo Kulonprogo.

Fenomena perkembangan wayang wong gaya Yogyakarta di luar tembok istana ini tentunya berkembang menurut spirit komunal yang selaras dengan kebutuhan dan kualitas seniman pendukungnya, terutama pengetahuan dan kemampuan keterampilan tekniknya. Oleh karena itu, tulisan kali ini lebih difokuskan pada garap, dan berbagai pengaruh yang turut membentuk garap tersebut, baik social budaya maupun dari pemngaruh kesenian lainnya. Fenomena wayang wong pedesaan di Donomulyo Nanggulan Kulon Progo adalah produk seniman pedesaan yang
Surojo (Wayang Wong Langen Lestari Budoyo Donomulyo Sebuah Kajian Gaya Wayang Wong Pedesaan)

mengacu pada wayang wong gaya Yogyakarta. Grup kesenian ini adalah sebuah bentuk kesenian yang aktual sebagai hasil persebaran dan perkembangan sebelumnya, di mana unsur-unsur yang turut mempengaruhi sangat kompleks, baik aspek kesejarahannya secara linier dari Kridha Beksa Wirama maupun aspek sosial budaya masyarakat yang senantiasa mengalami perubahan sesuai spirit zamannya..

\section{Proses Pembentukan}

Proses pembentukan wayang wong Lestari Budaya erat kaitannya dengan pertemuan dua budaya yaitu budaya besar (istana) dan budaya kecil (rakyat). Hal ini merupakan bentuk persebaran budaya yaitu berangkat dari keraton Kasultanan Yogyakarta yang berfungsi sebagai salah satu pusat kebudayaan Jawa yang dikenal seni tradisi klasik menuju ke pedesaan sebagai salah satu pusat kebudayan yang dikenal seni tradisi rakyat. Proses pembentukannya ditandai oleh kuatnya pengaruh seni tradisi keraton terhadap seni tradisi rakyat, sehingga menghasilkan bentuk gaya seni ysng khas pedesaan sebagai formalitas budaya keraton yang "ndeso". Seperti dikemukakan oleh D.H. Burger:

Gaya hidup Jawa ini berakar dalam khazanah kebudayaan yang terhimpun dalam kesusasteraan kuno dan dalam wayang (pertunjukan pemainan bayangan yang diiringi musik dan seni tari). Wayang mempunyai makna keagamaan. Pertunjukan wayang diadakan pada saat-saat terpenting dalam kehidupan manusia seperti kelahiran, perkawinan dan khitanan, juga untuk mengelakkan mala petaka atau menghalau penyakit, dan segala pengaruh lain yang merusak. Pertunjukan wayang merupakan tontonan suci. Karena leluhur yang didewakan muncul di atas pentas. Terutama kaum bangsawan menganggap tokoh-tokoh wayang itu nenek moyang mereka (Burger, 1983: 4344)

Latar belakang ini sebenarnya mengilhami keberadaan wayang wong Lestari Budaya di Desa Donomulyo, yakni formalitas budaya keraton sebagai khazanah penghayatan terhadap dunia spiritualitas orang Jawa yang "ndeso". Persamaan persepsi bangsawan keraton dengan rakyat kecil yang "ndeso" terhadap budaya wayang, bahwa seni 
kuno adalah satu ungkapan dari pandangan hidup Jawa yang kuno, yang didukung oleh "rasa kerukunan alam semesta (Ibid.,: 75)

Pemaknaan budaya keraton dalam konteks budaya pedesaan tentu diyakini sebagai unsur pembentuk karakter masyarakat pedesaan dalam pengukuhan jatidiri mereka sebagai bentuk media legitimasi komunal yang "ndeso". Masyarakat pedesaan Jawa dalam menentukan identitas kebudayaan cenderung menerima pancaran budaya keraton yang diaktualisasikan dalam spirit komunal sebagai pernyataan yang menyatukan tata nilai kawula-gusti. Pernyataan seni tradisi pedesaan ini merupakan pencerminan dari kesederhaaan dasn kepolosan berpikir fan bertindak dalam dunia kesenian yang diukur menurut kemampuan mereka, sehingga ekspresi individual dan kolektif lokalitas memberi gambaran tentang keseimbangan dunia manusia dan alam semesta.

Pada awal keberadaan Kridha Beksa Wirama sebenarnya dilatarbelakangi oleh antusias dan peminat para peserta didik yang mayoritas dari kalangan umum atau mereka yang berasal dari desa-desa, sehingga tidak mustahil tari keraton (baca wayang wong) berkembang secara luas di luar tembok keraton.. Namun karena belum tuntasnya pengusaan materi tari yang dipelajari di Kridha Beksa Wirama, maka perkembangan tarian keraton di pedesaan cenderung mengalami penurunan kualitas penguasaan dan keterampilan teknik gerak. Akibat dari proses pembentukan yang kurang optimal itu diyakini akan berdampak pada kualitas pengembangan wayang wong dari waktu ke waktu sejalan dengan perubahan zaman. Bercampuran dari berbagai gaya dan potensi seni di desa, merupakan fenomena sosial budaya sebagai proses pembentukan karakter identitas masyarakat pemilik kesenian itu.

Gaya wayang wong pedesaan ini adalah realitas kreativitas seniman pedesaan yang memiliki pemahaman dan interpretasi yang unik. Keunikan yang dimaksud adalah kesederhaaan dan kepolosan dalam menginterpretasikan seni tradisi istana dengan kemampuan apa adanya. Oleh karena itu, maka wayang wong gaya pedesaan ini memiliki ciri khas, versi dan gaya yang berbeda menurut atmosfir budaya di pedesaan yang sederhana, apa adanya, "bentuk tari tampak belum selesai" dan unik bila dilihat dari sisi pandang kesenian keraton. Seluruh ciri-ciri kompleks ini sebenarnya merupakan unsur pembentuk suatu gaya seni sebagai dikemukakan oleh Anya
Peterson Royce. Gaya tersusun dari simbol, bentuk, dan orientasi nilai yang mendasarinya. Bentuk dan simbol terang-terangan memasukkan pakaian, bahasa, musik, tari, tipe rumah, dan agama (Royce, 2007: 171). Transformasi tata riasbusana tentu disesuaikan dengan ketersediaan dan kualitas bahan yang didasarkan pada kemampuan daya beli mereka serta kemampuan menginterpretasinya. Di samping itu, pengalaman mereka ketika melihat pertunjukan tertentu yang memberi inspirasi variasi warna dan desain tata busana. Transformasi gerak tari sangat jelas dilatarbelakangi oleh kekurang sempurnaan penguasaan pengetahuan dan keterampilan teknik ketika mereka menjadi murid KBW, sehingga kesederhanaan bentuk gerak dan cara pengungkapannya menjadi unik yang menandai gaya "ndeso". Tipe rumah atau panggung pertunjukan juga sangat tergantung dari fasilitas ruang pentas yang disebut pendopo atau panggung yang dibuat untuk kepentingan pertunjukan. Keseluruhan unsur pembentuk gaya itu ditunjang oleh nilai-nilai etika, moral dan spirit yang ada dalam wayang sebagai media pendidikan budi pekerti orang Jawa tempo dulu, dan mungkin masih berlaku di masa kini dan masa yang akan datang.

Jennifer Liindsay dalam penelitiannya melihat sebuah perjalanan panjang wayang wong sendiri di keraton dikategorikan menjadi klasik, kitch dan kontemporer. Dengan batasan ketiga istilah ini ditemukan perbandingan dan tolok ukur pada "waktu pertunjukannya". Pertunjukan di masa Hamengku Buwana I hingga masa Hamengku Bubawa VIII telah mengalami perbedaan bentuk. Artinya, bahwa aspek "waktu" yang bersifat diakronis dalam tempat yang sama cenderung mengalami perubahan bentuk sejalan dengan spirit masyarakat pendukungnya sebagai kreator dan innovator karya seni. Persebaran ke arah luar keraton di mana lingkungan masyarakat pendukung budaya tidak sama dengan masyarakat keraton tentu interpretasi akan mengalami penyesuaian dengan potensi budayanya, sehingga produk budaya yang diciptakan akan memiliki kualitas sendiri, termasuk ukuran estetiknya. Hal ini sesuai dengan pemahaman teori difusi yang menunjuk adanya pusat budaya dan luar pusat budaya, yakni seni tradisi keraton yang dibawa oleh individu yang berstatus abdi dalem untuk dikembangkan di daerah asalnya. Unsur-unsur yang membentuk wayang wong pedesaan ini cenderung dikolaborasikan menurut 
JOGED

ISSN: $1858-3989$

kemampuan dan selera seniman pendukungnya. Kasus pembentukan koreografi wayang wong Lestari Budaya ini lebih mencerminkan suatu proses kreatif dengan memadukan unsur-unsur wayang wong gaya Yogyakarta, unsur-unsur seni tradisi lokal, atau unsur lain seni lainnya sebagai pengalaman berkesenian mereka, sehingga kesan kepolosan dan kesederhanaan berpikir mereka serta keterbatasan kemampuan penguasaan dan keterampilan teknik tentu berakibat pada kualitas bentuk koreografi.

Kesenian tradisional ini adalah sebuah bentuk seni yang bersumber dan berakat serta telah dirasakan sebagai miliki sendiri oleh masyarakat lingkungannya. Penciptaan karya seni ini didasarkan atas cita-rasa masyarakat pendukungnya. Cita-rasa menunjuk pada pemahaman pengertian yang luas, termasuk nilai kehidupan tradisi, pandangan hidup, pendekatan falsafah, rasa etis dan estetis serta ungkapan budaya lingkungan (Jennifer Lindsay, 1991). Totalitas keseluruhan ungkapan budaya ini merupakan pencerminan integritas individu dan kelompok terhadap tata nilai yang diyakini menjadi sumber inspirasi untuk menjaga tertib sosial dalam upaya mencapai cita-cita bersama sebagai kearifan budaya lokal. Ketika kesenian tradisional itu mengalami perubahan sesuai dengan spirit zamannya, maka kesenian itu bersifat kontemporer atau seni kitsch yang ditujukan untuk kepentingan dan kebutuhan estetis dan hiburan masyarakat pendukungnya. Pertunjukan kitch bagi wayang wong di luar keraton dipahami adanya pergeseran fungsi pertunjukan dan tempat pertunjukan. Ketika wayang wong berada di luar keraton dan beralih fungsi sebagai hiburan, maka seni pertunjukan itu merupakan genre yang dikemas untuk kepentingan komunal dan suatu pernyataan ekspresi kolektivtas mereka sebagai rakyat pedesaan. Seni kitch dan bukan kitch dapat dibedakan hanya karena fungsi pertunjukan, sedang pandangan klasik dan bukan klasik tergantung dari menyimpang atau tidaknya dari kaidah-kaidah tari klasiknya. (Jennifer Lindsay, 1991).

Keseluruhan hasil interpretasi dan kreativitas kolektif seperti tercermin pada gaya wayang wong pedesaan merupakan suatu pernyataan budaya dari sistem pengetahuan masyarakat terhadap wayang wong tentang kehidupan manusia sebagai media pendidikan dan komunikasi untuk meningkatkan kualitas manusia dalam memahami tata nilai etika dan moral serta spiritual agar manusia mampu
Surojo (Wayang Wong Langen Lestari Budoyo Donomulyo Sebuah Kajian Gaya Wayang Wong Pedesaan)

menjaga keseimbangan mikrokosmos dan makrokosmos. Sistem pengetahuan tentang wayang secara tersirat dan tersurat merupakan simbol kehidupan manusia yang mewakili tentang sifat baik dan buruk, sehingga simbol-simbol itu memiliki sistem nilai yang dipakain acuan normatif untuk diimplementasikan dalam berinteraksi dan berkomunikasi dengan sesama manusia dan lingkungan.

Jika melihat teks koreografi wayang wong Lestari Budaya sebenarnya transformasi koreografi wayang wong pedesaan ini dapat dikategorikan merupakan bentuk kitch atau kontemporer dari sebuah daya kreatifitas seniman pemangkunya (lihat Jeniffer Liindasy). Menurut Hersapandi, wayang wong gaya Surakarta telah mengalami perubahan status dan fungsi yaitu dari seni istana menjadi seni komersial. Komersialisasi wayang wong yang dibarengi kualitas bentuk menjadikan seni wayang wong yang berkembang di daerah Surakarta menjadi meluas dan disukai masyarakat urban di kota-kota besar di Jawa (Hersapandi, 1999). Kemasan wayang wong komersial dibarengi dengan penggunaan teknologi canggih dalam pertunjukannya, misalnya: tata panggung, tata suara, tata lampu dan segi-segi lain (trik-trik) yang dapat menarik penonton. Namnun karena wayang wong Lestari Budaya bukan merupakan seni peruntjukan yang bersifat komersial, tetapi sebagai pertunjukan yang bersifat komunal, maka kegiatan pentasnya disposori oleh masyarakat dan masyarakat sebagai basis sosial diberi kesempatan menonton secara gratis. Artinya, bahwa masyarakat sebagai konsumen dan sekaligus sebagai pelindung kesenian di pedesaan.

Proses pembentukan wayang wong Lestari Budaya tentu tidak dapt dipisahkan dengan peran organisasi kesenian yang dibentuk untuk kepentingan ituy. Menurut Y. Sumandiyo Hadi, bahwa kelembagaan kesenian atau organisasi kesenioan dimaknai sebagai agen of change di mana actor di dalamnya merupakan agen yang mampu menggerakkan roda organisasi untuk mencapai tujuan. Misalnya, KBW pada saat tahun 50-an menjadi kancah pembelajaran penari-penari desa dan kemudian setelah kembali ke desa baik belajarnya tuntas maupun belum tuntas, mereka berkarya di desanya. Dengan modal dan kemampuan yang terbatas itu, tampaknya spirit untuk mendirikan organisasi kesenian merupakan tekad dan cita-cita mereka sebagai kawula kerajaan Kasultanan Yogyakarta untuk berperan serta dalam mengaktualisasikan pencitraan seni keraton di 
wilayah pedesaan. Komunitas atau lembaga baru di desa itu berfungsi sebagai perwakilan seni keraton di pedesaan, yang implementasinya merupakan sebuah pernyataan social dari suatu komunitas pedesaaan.

\section{Wayang Wong Donomulyo Sebagai Bentuk Seni Gaya Pedesaan}

Keberadaan wayang wong di desa Donomulyo tidak bisa lepas dari sejarah pembentukannya. Pada tahun 1932 seorang guru sekolah Kawula Kasultanan bernama R. Sanghadi memiliki seperangkat gamelan. Oleh masyarakat Klangon, Sedayu dan Moyudan sering digunakan uyon-uyon. R. Sanghadi sendiri selain sebagai guru juga merupakan abdi dalem keraton yang aktif. Menurut Sumanggakarso guru karawitan di Klangon menceritakan keadaan Klangon wilayah perbatasan dengan kabupaten Kulon Progo, merupakan daerah strategis untuk pengembangan kesenian. Di rumah R. Sanghadi sendiri telah digunakan latihan Langen Mandra Wanara dengan lakon Sugriwa-Subali. Menurut surat kekancingan nomor 9726 tertanggal 4 April 1932 R. Sanghadi ditetapkan sebagai putra Mangkusentana diberi tanggung jawab dari pihak keraton untuk membuka sekolah Kasultanan di Moyudan.

Pada tahun 1945 hingga tahun 1950 peran KBW semakain nyata dengan melibatkan warga masyarakat dari berbagai daerah, terutama kegiatan tari yang mermunculkan banyak tokoh penari, seperti muncullah generasi Sumanggakarso yang menghimpun penari-penari di rumahnya di Klangon. Kesungguhan belajar menari generasi muda Klangon dibuktikan pernah datangnya guruguru dari KBW meresmikan Balai Kesenian Klangon seperti K.R.T. Kusumabrata, K.R.T. Pringgabrata dan K.R.T. Jagabrata. Hal ini menunjukkan bahwa persebaran budaya dari pusatnya ke daerah berjalan secara baik dan berkesinambungan melalui pewarisan menurut garis hubungan petemanan dan kaderisasi seniman lokal. Wilayah pengembangan Balai Kesenian Klangon terdiri dari penduduk Kulon Progo hingga daerah pelosok di kaki pegunungan Menoreh. Singkat kata wayang wong di tahun-tahun berikutnya telah berkembang di daerah Sentolo dan Donomulyo. Di rumah Suwardi di Banguncipto Sentolo Kulon Progo merupakan tempat berkembangnya wayang wong yang sangat berarti bagi perkembangan wayang wong di Donomulyo.
Sarjono murid tari dari Suwardi yang tinggal di Donomulyo mengatakan :

“ kula angsal kapinteran joged menika sangking Pak Wardi ing Banaran Banguncipto. Griyanipun wiyar lan kangge gladhen wayang wong. Piyambakipun menika ingkang langsung nate sinau dhateng Kridha $(K B W)$, menawi kula dereng nate. Kula sak kanca kalih Mudiharjo angsal latihan saking Pak Wardi kemawon. Kula dereng nate sinau joged wonten kridha, namung mireng kemawon".

(saya bisa menari dari Pak Wardi di Banaran Banguncipto, rumahnya luas dan untuk wayang wong. Dia (Pak Wardi) yang pernah belajar dari kridha, kalau saya belum pernah. Saya dengan teman-teman termasuk Mudiharjo mendapat pelajaran dari Pak Wardi saja).

Berbekal 13 jenis motif gerak yang dikuasainya, Sarjono dan Mudiharjo mendirikan kelompok wayang wong di Donomerto Donomulyo. Namun kelompok ini tidak terlalu lama berlangsung. Berkat kegigihan Harjo Sukirno ayah Siswo Prajono, kemudian latihan dipusatkan di dusun Jambon hingga sekarang. Siswa Prajono yang menjadi pimpinan wayang generasi sekarang mengakui bahwa wayang wong di Jambon adalah kelanjutan dari wayang wong Donomerto, bahkan setiap akan mengadakan pergelaran melibatkan pengasuh terdahulu yaitu Sumidi, Sastyradiwiryo dan Sarjono. Siswa Prajono sendiri dalam hal penyutradaraannya banyak dibimbing oleh seorang dalang Sastra Sencaka.

Sarjono sebagai nara sumber wayang wong Jambon ini mengatakan :

\section{“ Lare-lare Jambon sakmenika remen dhateng kesenian lan majeng, nanging sampun mboten disiplin anggenipun sinau joged. Kalang kinantang rojo menika kedahipun angklung-angklung mekaten, mboten ngepel kados kambeng”.}

(Anak-anak Jambon sekarang senang terhadap kesenian, dan maju tetapi sudah tidak begitu disiplin dalam belajar menarinya. Kalang kinantang rojo itu seharusnya melingkar demikian (sambil memperagakan), tidak ngepel seperti kambeng saja). 
JOGED

ISSN: $1858-3989$

Sesuai dengan tuntutan zaman yang sekarang sudah berubah ke masyarakat industri modern, yang dalam kehidupannya tidak lepas dari sarana hiburan dari media elektronik. Media elektronik seperti televisi, radio, VCD dan bentuk yang lain telah menawarkan berbagai pilihan dalam acaranya. Namun demikian masyarakat yang terhimpun dalam kelompok wayang wong masih setia untuk latihan dan mengadakan pergelaran tatkala dibutuhkan pentas. Wayang wong Donomulyo di samping tetap memelihara sekuat tenaga untuk bertahan dengan sajian klasik tradisi, juga menerima trend budaya yang sedang semarak misalnya campursari. Pada limbukan dan garagara trend budaya campursari menjadi favorit dan dinanti-natikan oleh penggemarnya. Tidak bisa tidak wayang wong Donomulyo sesuai fungsinya sebagai sarana hiburan masyarakat, bentuk sajiannya mengalami perubahan dan perkembangan.

\section{Wayang Wong Pedesaan sebagai Gaya Prayungan}

Hasil dari persebaran wayang wong dari keraton ke luar keraton sesuai denga teori difusi menyebabkan adanya bentuk baru yang berbeda dengan sumber aslinya. Wayang wong pedesaan yang telah mengalami sejarah panjang, akhirnya membentuk gaya tersendiri yang disebut prayungan. Prayungan menurut Slamet seorang dalang dan penari wayang wong yang kini menekuni tata rias dan busana khusus wayang wong, mengatakan bahwa perpaduan antara gaya Yogyakarta dan Surakarta terutama dalam hal tata gerak dan tata busana wayang tidak dapat dihindari. Hal ini disebabkan adanya permintaan masyarakat peminat wayang wong di pedesaan.

Di Yogyakarta pertunjukan wayang wong klasik keraton yang berkembang di luar keraton masioh terbatas pada perkembangan tarinya. Sedang di luar keraton juga sudah berkembang wayang wong panggung (komersial) gaya Surakarta. Dalam pertunjukan di panggung sajian wayang telah dikemas dengan bantuan tata busana dan tata teknik pentas yang sudah barang tentu lebih menarik, sedangkan wayang wong hasil perkembangan gaya Yogyakarta berkembang dengan sajian "pendapan" dan kelengkapan busana klasik yang bersifat sederhana sangat terbatas serta belum dibantu dengan tata busana dan tata panggung yang lebih menarik. Akibat dari itu
Surojo (Wayang Wong Langen Lestari Budoyo Donomulyo Sebuah Kajian Gaya Wayang Wong Pedesaan)

masyarakat lebih tertarik untuk menggunakan tata busana gaya Suraikarta yang tampak gebyar dan mewah.

Slamet tampaknya tertarik untuk memadukan kedua gaya tersebut mulai dengan karya miliknya dalam persewaan tata busana wayang. Sifat sederhana dan tanpa banyak warna pada kostum gaya Yogyakarta, tetapi Slamet tertarik desainnya terutama irah-irahan. Maka Slamet memberi warna sunggingan seperti gaya Surakarta sehingga terwujud perpaduan gaya yang disebutnya gaya prayungan itu. Dalam hal gerak tari, karakter dan tata laku, wayang wong pedesaan termasuk di Donomulyo ini umumnya berbekal tari dari KBW. Namun tata busana tidak sama sekali mengacu wayang keraton. Hal yang demikian disebabkan sulitnya di desa mendapatkan kostum gaya keraton, karena yang memiliki busana wayang keraton adalah keraton sendiri. Di samping busana wayang keraton tidak diperbolehkan keluar keraton, juga pengadaan kostum tari harus dengan cara memesan kepada pembuatnya serta dengan waktu yang lama dan relatif mahal harganya.

Perpaduan dua gaya yang muncul di wayang wong pedesaan lainnya adalah pada gerak tarinya. Gerak tari yang dilakukan oleh Slamet nampak menunjukkan gaya yang spesifik. Gerak kaki jujungan (genjot dan jomplang) menggunakan teknik gaya Yogyakarta sedang posisi tangan menggunakan pola gaya Surakarta. Teknik menari dengan pola gaya Yogyakarta yang kuat disebabkan pada umumnya bekas siswa KBW selalu mengikuti latihan dasar yang dikenal dengan "tayungan". Dalam tayungan ini ditekankan pada pentingnya gerak kaki di dalam mendasari tarian berkarakter apapun, sedangkan gerak tangan, leher dan lainnya menjadi prioritas kemudian. Seorang penari klasik diwajibkan memiliki "deg" yang benar, walau belum melakukan gerak sekalipun.

Gendhing pengiring pada wayang wong pedesaan lebih longgar, bahkan gendhinggendhing pedalangan gaya Yogyakarta menjadi pilihan utama dari pada gendhing-gendhing gaya Surakarta. Namun dalam hal kandha dan antawecana, wayang wong ini lebih mengacu pada gaya Surakarta. Kandha dan pocapan atau antawecana gaya keraton merasa kesulitan, sebab artikulasinya telah ditentukan dengan standart klasik yang ada, sedang gaya Surakarta lebih santai, longgar, tidak sulit dan komunikatif tidak jauh dari pola keseharian. Kandha dan pocapan gaya Surakarta dapat dilakukan secara spontan dan 
boleh dikembangkan sendiri, sedang gaya keraton Yogyakarta telah terstruktur dalam teks.

Kemampuan dan kemauan untuk belajar membaca dan mempelajari teks wayang wong gaya keraton merupakan beban tersendiri dan tidak semua penari dari desa ketika belajar di KBW sampai pada pelajaran kandha dan pocapannya. Kesenjangan inilah menjadikan wayang wong pedesaan tidak tuntas dalam menstranfer seluruh materi wayang wong keraton, sehingga yang terjadi adalah intrepretasi penari dari desa itu sendiri yang muncul dalam kreasinya serta mengadopsi dari gaya Surakarta dan gaya pedalangan.

\section{Penutup}

Wayang wong Lestari Budaya Donomulyo adalah produk budaya seniman pedesaan yang mengacu pada wayang wong gaya Yogyakarta. Hal ini merupakan bentuk persebaran budaya yaitu berangkat dari keraton Kasultanan Yogyakarta yang berfungsi sebagai salah satu pusat kebudayaan Jawa yang dikenal seni tradisi klasik menuju ke pedesaan sebagai salah satu pusat kebudayan yang dikenal seni tradisi rakyat. Proses pembentukannya ditandai oleh kuatnya pengaruh seni tradisi keraton terhadap seni tradisi rakyat, sehingga menghasilkan bentuk gaya seni ysng khas pedesaan sebagai formalitas budaya keraton yang "ndeso".

Wayang wong gaya pedesaaan ini mencerminkan ekspresi individu dan kolektif seniman desa yang mencoba untuk mendistribusikan seni istana menjadi seni rakyat pedesaan. Kualitas pengetahuan dan kemampuan keterampilan teknik gerak wayang wong cenderung rendah atau belum tuntas, sehingga gaya seni pedesaan ini justru melahirkan keunikan yang khas "ndeso" yang sederhana dan polos yang didukung oleh spirit komunal pedesaan untuk kepentingan media komunikasi pendidikan dan ritual.

Ekspresi kreativitas individu dan kolektif ini tentu diwariskan dari satu generasi ke generasi berikutnya dengan tingkat pemahaman artistik yang berbeda, sehingga bentuk pewarisan tradisi ini cenderung mengalami dinamika perkembangan sejalan dengan prubahan sosial budaya masyarakat pedesaan di zamannya. Hal ini diwarnai semakin terpinggirkan seni tradisi rakyat pedesaan sebagai akibat perkembangan budaya global yang mendominasi kehidupan masyarakat, terutama seni pop yang difasiitasi oleh media elektronik televisi.

\section{DAFTAR RUJUKAN}

\section{Burger, D.H., 1983, Perubahan-Perubahan Struktur Dalam Masyarakat Jawa, terjemahan}

Dewan Redaksi, Bhratara Karya Aksara, Jakarta.

Hersapandi, 1999, Wayang Wong Sriwedari: Dari Seni Istana Menjadi Seni Komersial, Yayasan

Untuk Indonesia, Yogyakarta.

Koentkaraningrat, 197, Sejarah Teori Antropologi, Universitas Indonesia Press, Jakarta.

Kuntowijoyo, 1987, Budaya dan Masyarakat, Taiara Macana, Yogyakarta.

Liindsay, Jenifer, 1991, Klasik Kitsch Kontemporer, Sebuah Studi Tentang Seni Pertunjukan

Jawa, terjemahan Nin Bakdi Sumanto, Gadjah Mada University Press, Yogyakarta.

Outhwaite, William,editor, 2008, Ensiklopedi Pemikiran Sosial Modern, edisi kedua, terjemahan

Tri Wibowo, Kencana Predana Media Gourp, Jakarta.

Royce, Anya Peterson, 2007, Antropologi Tari, terjemahan F.X. Widaryanto, Sunan Ampu Press, Bandung.

Rusliana, Iyus, 2002, Wayang Wong Priangan: Kajian Mengenai Pertunjukan Dramatari Tradisional di Jawa Barat, Kiblat Buku Utama, Bandung.

Soedarsono, 1999, Wayang Wong: The State Ritual Dance Drama in The Court of Yogyakarta, Gadjah Mada University Press, Yogyakarta. 


\title{
PERAN MAJLIS PUSAT PERTUBUHAN-PERTUBUHAN BUDAYA MELAYU SINGAPURA DALAM FESTIVAL TARI SERUMPUN
}

\author{
Oleh : \\ RAJA ALFIRAFINDRA
}

\begin{abstract}
Majlis Pusat Pertubuhan-Pertubuhan Budaya Melayu Singapura, merupakan satu di antara badan-badan Budaya Melayu yang tertua di Singapura. Sebelumnya dikenal Sriwana yang telah membuktikan dan memainkan peran dalam mengetengahkan warisan budaya Melayu di Singapura dari tahun 1955 sampai sekarang. Kedua badan ini berjalan seirama sesuai dengan peran masing-masing guna mengangkat martabat masyarakat Melayu di Singapura. Sriwana dalam kehadirannya lebih memokuskan pada kesenian baik tari, musik, dan teater, sedangkan Majlis Pusat Pertubuhan-Pertubuhan Budaya Melayu Singapura lebih menekankan pada pelestarian kegiatan keagamaan, kebangsaan, dan kebudayaan yang merupakan identitas budaya Melayu.
\end{abstract}

\section{Pendahuluan}

Perpisahan Singapura dari salah satu anggota persekutuan Malaysia pada tanggal 9 Agusttus 1965 telah mencetuskan keadaan yang kurang stabil pada kehidupan masyarakat Melayu Singapura. Perpisahan ini menyebabkan masyarakat Melayu Singapura harus mampu untuk menentukan masa depan mereka yang tinggal di dalam sebuah negara yang secara mayoritas bukan dari bangsa mereka. Masyarakat Melayu Singapura harus mencari jalan dengan upaya sendiri agar dapat menghidupkan agama Islam, kebangsaan, dan kebudayaan Melayu agar tidak hilang ditelan arus perubahan masyarakat di negara yang metropolis itu.

Tahun 1967, muncul upaya untuk menyatukan langkah-langkah guna melestarikan kegiatan keagamaan, kebangsaan, dan kebudayaan Melayu Singapura. Pada tanggal 12 April 1969, terbentuklah Majlis Pusat Pertubuhan-Pertubuhan Budaya Melayu Singapura yang menjadi penggerak utama dalam upaya pelestarian dan pengembangan budaya melayu Singapura. Dalam perkembangannya Majlis Pusat PertubuhanPertubuhan Budaya Melayu Singapura ini lebih dikenal dengan sebutan Majlis Pusat. Visi Majlis Pusat ini menekankan pada kepimpinan mandiri dalam persatuan bangsa, memelihara serta membangun budaya Melayu dan negara. Adapun misi Majlis Pusat Pertubuhan-Pertubuhan Budaya Melayu Singapura memainkan peran utama bagi usaha melestarikan budaya Melayu serta nilai-nilai nuraninya dalam konteks masyarakat Singapura yang berbilang kaum yang majemuk sekaligus menyumbang ke arah pembangunan negara.

Terbentuknya Majlis Pusat PertubuhanPertubuhan Budaya Melayu Singapura pada tahun 1969, memberi angin segar bagi perkumpulanperkumpulan Melayu yang berada di seluruh wilayah Singapura dengan kegiatan yang utuh dan menyatu di bawah naungan Majlis Pusat. Seluruh kegiatan masyarakat Melayu Singapura yang dikoordinir oleh Majlis Pusat lebih ditekankan kepada pendidikan, kemasyarakatan, keagamaan, olahraga, kesenian, kepemudaan dan kebudayaan Melayu pada khususnya (wawancara dengan Cekgu Hisam). Pada perkembangan selanjutnya, muncul perkumpulan yang mengembangkan pada kegiatan kebudayaan dan kesenian. Perkumpulan Persatuan Kemuning dan perkumpulan Seni Kedua yang pertama terbentuk, kedua perkumpulan ini sangat aktif dalam bidang tari, musik, dan teater yang menitikberatkan pada kesenian Melayu di Singapura, sehingga menjadi duta kesenian Majlis Pusat pada masa itu. Pada perkembangan selanjutnya, kedua perkumpulan ini memisahkan diri dari Majlis Pusat, sehingga Majlis Pusat mendirikan perkumpulan yang diberi nama Kirana Seni yang khusus menekankan pada tari Melayu. 


\section{Peran Negara dalam Perkembangan Budaya Melayu}

Singapura merupakan sebuah negara kecil yang luasnya lebih kurang $704 \mathrm{~km} 2$, dengan jumlah penduduk ras Melayu lebih kurang 659.000 orang. Dalam hal pelestarian budaya Melayu, negara memelihara banyak kumpulan tari, baik kumpulan yang sudah mapan, sekolah-sekolah, dan perorangan di bawah kelompok-kelompok masyarakat yang biasa disebut kelab-kelab masyarakat sesuai lokasi daerah masing masing. Kehadiran mereka dibantu oleh negara dalam bidang keuangan dan fasilitas, melalui Majlis Seni Kebangsaan, sesuai kebutuhan masing-masing kumpulan.

Kementrian Pendidikan Singapura setiap 2 (dua) tahun sekali mengadakan pertandingan tari yang diikuti seluruh sekolah rendah, menengah, dan mahtab rendah. Pertandingan Singapore Youth Festival ini, ternyata sangat diminati seluruh pelajar Singapura guna memperebutkan anugerah berupa emas dan perak sebagai hadiahnya. Sedangkan materi pertandingan tari lebih difokuskan pada tari kreasi yang berdasarkan konsep tradisional dan kontemporer Melayu.

Fasilitas dalam pengembangan tari Melayu di Singapura dari pihak Majlis Pusat dan Taman Warisan Melayu beberapa kali mengadakan pelatihan tari Melayu untuk pelajar dengan mendapat bantuan dari Majlis Seni Kebangsaan, dengan mengundang beberapa koreografer tari Melayu dari Indonesia salah satunya adalah penulis (Raja Alfirafindra). Beberapa kumpulan tari Melayu yang sudah mapan banyak juga mengirimkan penari, dan pemusik untuk belajar di Indonesia.

Majlis Pusat dalam perkembangannya dekade sekarang ini, lebih memberikan ruang pada kumpulan-kumpulan seni yang menekankan pada seni pertunjukan Melayu Singapura. Hal ini dapat dilihat dari struktur organisasi yang mengetengahkan seni Melayu Singapura antara lain:

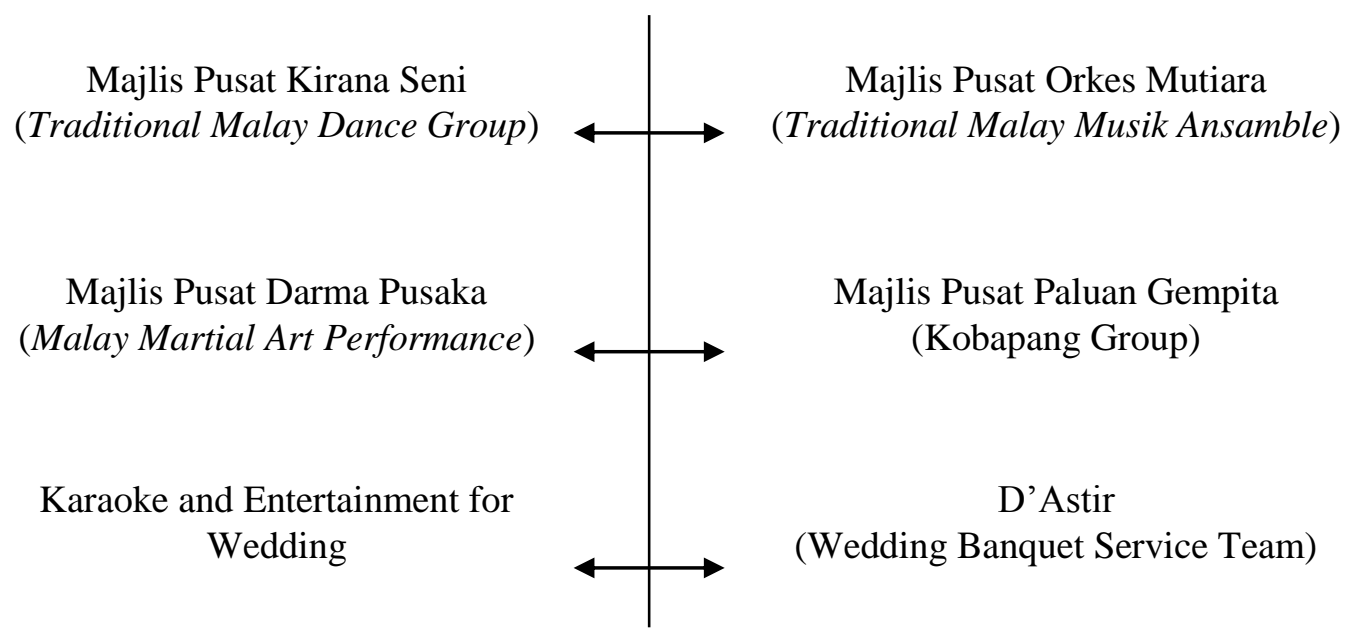

PERSATUAN PECINTA WARISAN TEMASEK (PPWT)

(KERIS \& MALAY WEAPON CONNOISSEURS)

\section{Perkembangan Budaya Melayu Singapura}

Sejarah tari Melayu Singapura sedikit banyak dipengaruhi oleh industri perfilman yang mengangkat tari Melayu dalam cerita-cerita sejarah Melayu serantau. Pertunjukan teater Bangsawan, banyak terlibat dalam pembuatan perfilman di
Singapura seperti artis, aktor, penari, pemusik, sutradara, dan tenaga lainnya yang terlibat dalam pertunjukan teater Bangsawan. Sutradara Melayu yang terkenal pada masa itu adalah P.Ramlee, mengangkat film Melayu dengan pertunjukan tari dan lagu Melayu, sebagai citarasa keMelayuan. Pada film-film Melayu yang disutradarai oleh 


\section{JOGED}

ISSN: $1858-3989$

P.Ramlee, tari dan lagu Melayu menjadi identitasnya. Selain P.Ramlee, adalah Omar Rojik dan Jamil Sulong yang berkecimpung di dalam studio Malay Film Production di jalan Ampas, dan sutradara lainnya seperti S.Roomai Noor, M.Amin dan Salleh Ghani di bawah naungan studio ChatayKeris selalu menggunakan tari dan lagu Melayu sebagai identitas mereka. Industri perfilman Melayu di Singapura lahir pada tahun 1933 hingga 1972, telah melahirkan pula penata tari yang terkenal pada masa itu. Di Shaw Malay Production penata tari seperti Osman Gumanti yaitu penari dan aktor dalam pertunjukan sandiwara yang berasal dari Sumatera-Indonesia, Habsah Buang, Normadiah dan Rahmah Rahmat. Penata tari Habsah Buang dan Normadiah mendapat tempat yang terhormat dengan karya tari mereka yang dikuti oleh penata tari di luar perfilman seperti tari "Semerah Padi", tari "Tudung Periuk", tari "Tualang Tiga" ciptaaan Normadiah. Karya karya tari yang diciptakan oleh Normadiah dan Habsah Buang menjadi tolok ukur dalam perkembangan tari Melayu di Singapura sampai sekarang ini. Memang ada perbedaan tari yang dipertunjukkan untuk film dengan tari yang dipertunjukkan pada pentas Sandiwara Bangsawan. Film-film yang mengetengahkan tari Melayu dari Studio ChatayKeris Film Production adalah tari "Lancang Kuning", tari "Selendang Delima", tari "Cucu Datok Merah" dan tari "Bawang Putih Bawang Merah". Perkembangan film Melayu yang tumbuh subur pada saat itu, menyebabkan kehadiran penata tari bertambah regenerasi seperti: Suryati Arifin dengan karya tari "Sirih Pinang", Fatimah Syarif dengan karya tari "Bentan Telani", dan Norsiah Yem dengan karya tari "Nuri Bertuah".
Raja Alfirafindra (Peran Majlis Pusat Pertubuhan-Pertubuhan Budaya Melayu Singapura dalam Festival Tari Serumpun)

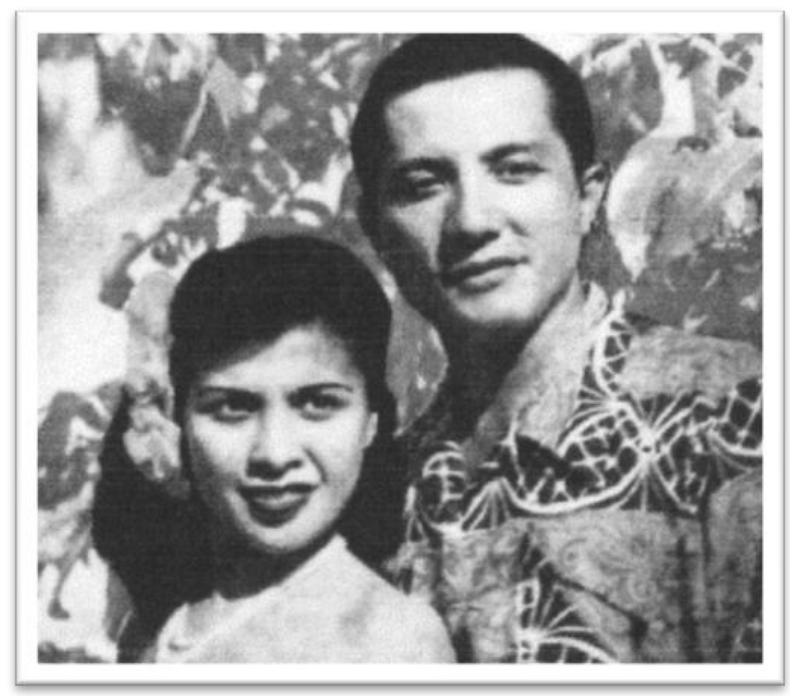

Gambar 1:

Osman Gumanti bersama Dato’ Maria Menado dalam Film Pulau Mutiara, 1951

(sumber: dokumentasi pribadi Cekgu Hisam)

Nama Habsah Buang dan Normadiah mendapat tempat sebagai penata tari terkenal setelah karya tari mereka menjadi acuan para penari di luar studio perfilman. Karya tari Normadiah adalah tari "Semerah Padi", tari "Tudung Periuk" dan tari "Tualang Tiga". Tariantarian tersebut merupakan karya baru yang berlandaskan tari tradisional yang diwarisi masyarakat Melayu Singapura dengan memasukkan unsur-unsur baru.

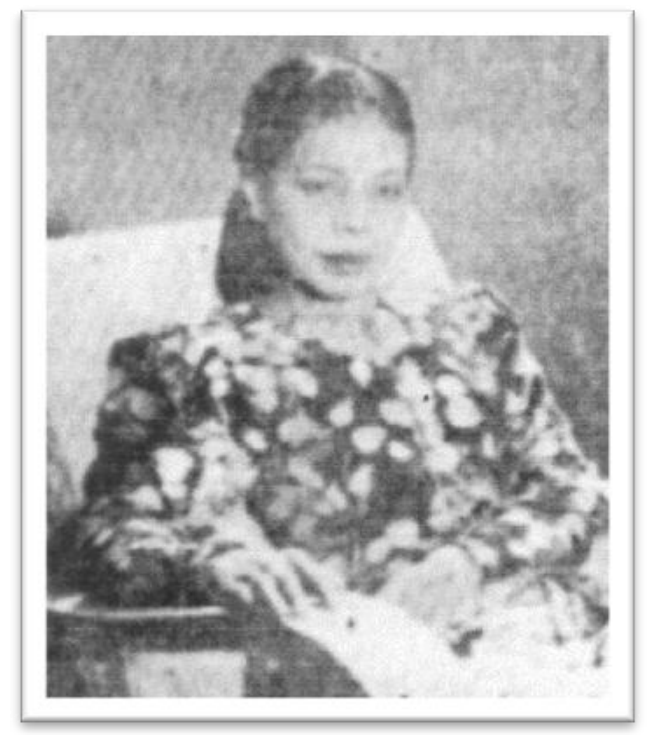

Gambar 2. Habsah Buang (koleksi: Cekgu Hisam) 


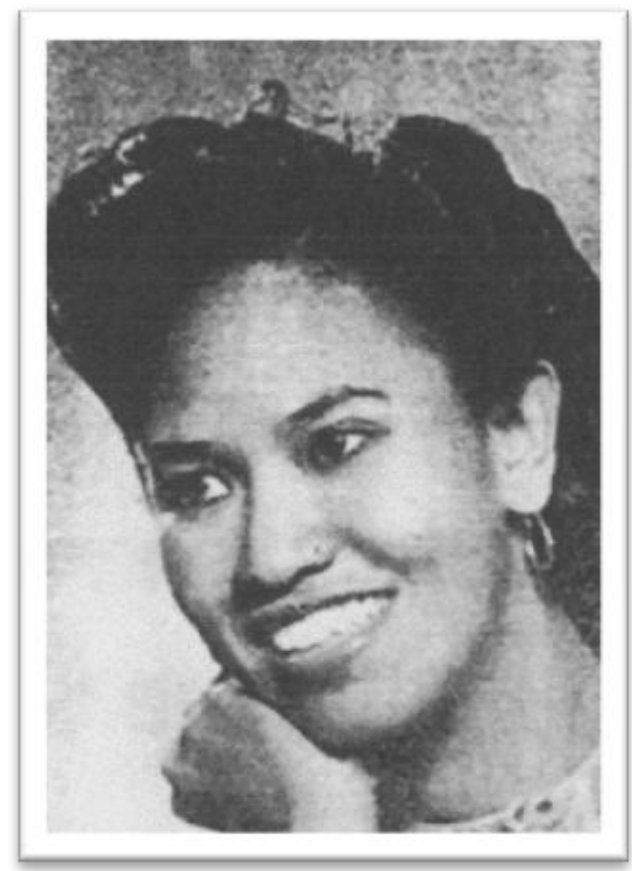

Gambar 3. Normadiah (koleksi Cekgu Hisam)

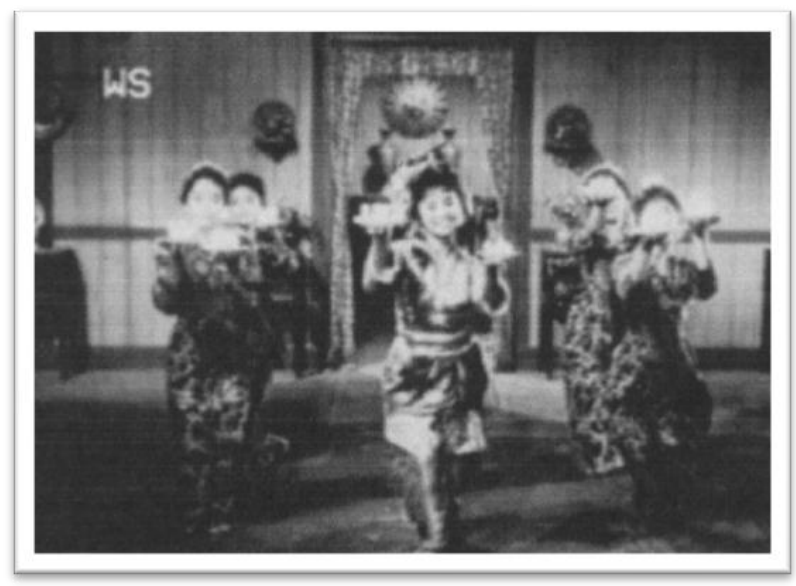

Gambar 4:

Tari Nurih Bertuah dalam Film Cucu Datuk Merah

(sumber: dokumentasi pibadi Cekgu Hisam)

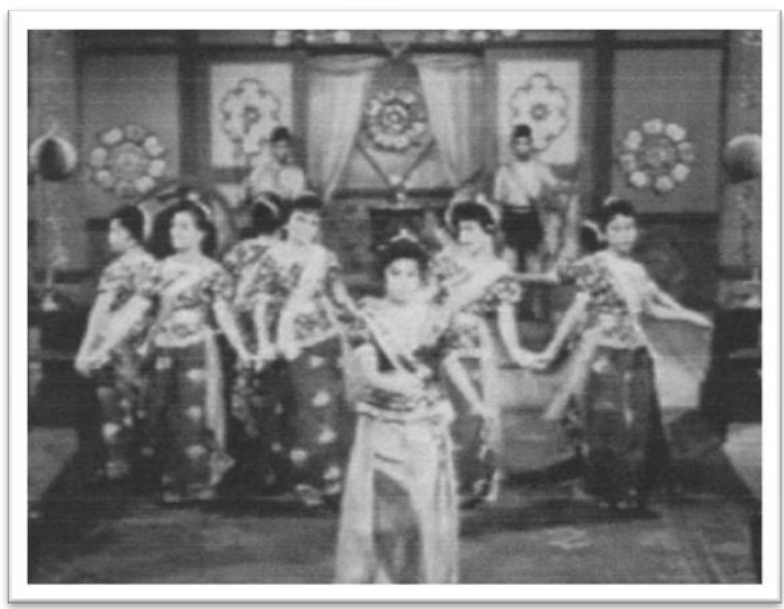

Gambar 5. Tarian Bentan Telani dalam Film Lancang Kuning (sumber: dokumentasi pribadi Cekgu Hisam)

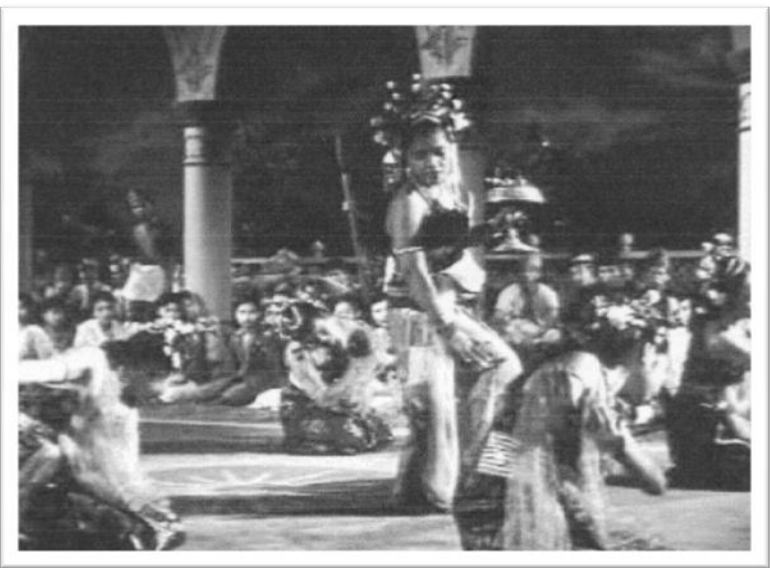

Gambar 6. Tari Sirih Pinang dari Film Bawang Putih Bawang Merah

(sumber: dokumentasi pribadi Cekgu Hisam)

\section{Peran Majlis Pusat dalam Perkembangan Budaya Melayu}

Majlis Pusat merupakan salah satu penggerak utama dalam perkembangan seni tari Melayu di Singapura. Majlis Pusat Pertubuhan-Pertubuhan Budaya Melayu Singapura merupakan satu di antara lembaga budaya Melayu yang tertua di Singapura yang telah banyak memberikan perkembangan budaya Melayu baik di dalam muapun di luar dengan tidak meninggalkan identitas Melayu itu sendiri. Hal ini dapat dilihat dari beberapa kegiatan yang pernah dilaksanakan oleh lembaga ini dalam mengetengahkan seni pertunjukan dalam hal ini tari Melayu yaitu: 
JOGED

ISSN: 1858-3989

\section{Festival Tari Serumpun}

Pertama kali dilaksanakan pada tanggal 19 September 2004 di Singapura. Pada Festival Tari Serumpun mengetengahkan bentuk Joget sebagai materi dalam penyajiannya. Hal ini disebabkan kesepakatan dari Majlis Pusat Pertubuhan-Pertubuhan Budaya Melayu Singapura untuk mengembangkan bentuk Joget sebagai ikon Majlis Pusat dalam penyelenggaraaan Festival Tari Serumpun. Menurut salah satu koreografer Kirana Seni, Cekgu Norlie Ismail, Festival Tari Serumpun dengan mengetengahkan bentuk Joget terinspirasi dari beberapa lawatan dan mengikuti festival di Indonesia terutama di Kepulauan Riau. Di daerah Riau banyak sekali bentuk bentuk joget yang berkembang antara lain: Joget Mak Dare, Joget Kak Long, Joget Mak Cik Norma, Joget Mantang, yang dulunya cukup terkenal di Singapura dan banyak dipelajari dalam kumpulan Sriwana pada masa itu, namun sekarang koreografer-koreografer muda Singapura tidak lagi memahami secara matang konsep Joget tersebut.

Di Indonesia terutama di Kepulauan Riau bentuk Joget masih hidup dengan pola-pola koreografi aslinya. Pemerintah Kabupaten Karimun mengetengahkan sebuah festival
Raja Alfirafindra (Peran Majlis Pusat Pertubuhan-Pertubuhan Budaya Melayu Singapura dalam Festival Tari Serumpun) dengan latar belakang bentuk Joget yang diberi nama Festival Dangkong. Dari sini Majlis Pusat mencoba untuk memberi ruang bentuk joget dalam Festival Melayu Serumpun. Salah satu koreografer didatangkan dari Kabupaten Karimun yaitu Suryaminsyah untuk membantu mengemas acara tersebut dengan mengadakan pelatihan, dan kolaborasi dengan sanggar Awang Sambang yang dipimpin Suryaminsyah dengan Kirana Seni Majlis Pusat (wawancara dengan Cekgu Norlie Ismail). Malaysia, dan Indonesia terlibat dalam acara ini. Dari Indonesia peserta didatangkan antara lain dari Kabupaten Bengkalis Riau, Kabupaten Indragiri Hilir Riau, Kabupaten Karimun Kepulauan Riau.

Festival Tari Serumpun kedua dilaksanakan pada tahun 2006, Festival Tari Serumpun ketiga dilaksanakan pada tahun 2008 dan pada tahun 2011 dilaksanakan Festival Serumpun keempat dengan jangkauan lebih luas dengan mengundang Brunei Darussalam, Pattani Thailand, Malaysia, Singapura, dan Indonesia. Pada acara lain Kirana Seni seringkali mengikuti beberapa festival tari melayu di Indonesia antara lain di Pekanbaru, Karimun, Bengkalis, dan Tembilahan.

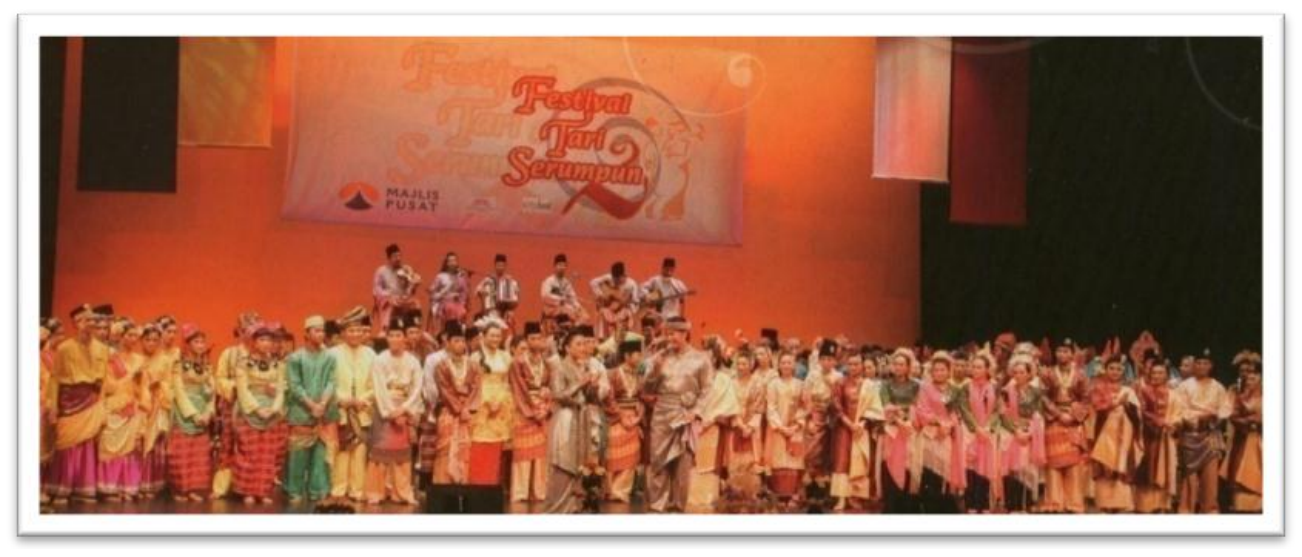

Gambar 7. Festival Tari Serumpun

yang diselenggarakan oleh Majlis Pusat Singapura

(dokumentasi: Majlis Pusat Singapura)

\section{Rewang Nak Tari}

Rewang Nak Tari merupakan usaha awal dari Majlis Pusat untuk mengetengahkan kumpulan-kumpulan tari Melayu Singapura. Pertunjukan pertama digelar pada tanggal 8 Juli 2007 untuk menyatukan rasa kebersamaan dalam perkembangan seni tari 
Melayu di Singapura, melalui sanggarsanggar tari Melayu. Keberhasilan Majlis Pusat dalam mengadakan produksi tari Rewang Nak Tari, memberi motivasi kepada sanggar-sanggar tari Melayu Singapura untuk membuat produksi tari dengan kesamaan yang dilakukan oleh Majlis Pusat.

Sanggar tari Melayu Singapura yang menjadi acuan dari karya-karya tari Melayu yang berkembang di Singapura antara lain: Sri Warisan, koreografer Som Said; Sriwana, koreografer Fauziah Hanun; Era Dance Theatre, koreografer Osman Hamid; Aspirasi koreografer Azmi Johari; Attri Dance Foundation, koreografer Rizal Yusuf; Dian Dancer dengan koreografer M. Yazid; Artis Budaya Tepak Sirih, koreografer Rizman; Atrika Dancer, koreografer Mazlina Buang Kasim; Perkumpulan Seni, koreografer Kama Ridzuan; Dharma, koreografer Faturahman Said; Kirana Seni koreografer Norlie Ismail. Acara Rewang Nak Tari merupakan salah satu perwujudan keberhasilan Majlis Pusat dalam memberikan peluang bagi kelompok tari yang dibentuk oleh Majlis Pusat yang diberi nama Kirana Seni. Kelompok Kirana Seni terbentuk pada tanggal 4 April 2003 dengan koreografer Cikgu Norlie Ismail yang cukup terkenal dan sudah lama berkecimpung di dunia tari Melayu sejak tahun 1974. Sebelumnya ia adalah seorang penari di Sriwana yaitu sebuah kumpulan kesenian yang terbentuk pada tahun 1950 yang dipimpin oleh Nong Chik Ghani.

Sriwana boleh dikatakan sebagai tempat mencetak penari dan koreografer Melayu di Singapura. Sekarang ini sebagian besar kumpulan tari Melayu di Singapura, koreografernya pada umumnya pernah belajar di Sriwana sebagai cikal bakal mencetak penari penari Melayu yang handal. Dalam acara Rewang Nak Tari sebagian besar koreografi yang ditampilkan kebanyakan lebih kepada bentuk joget.

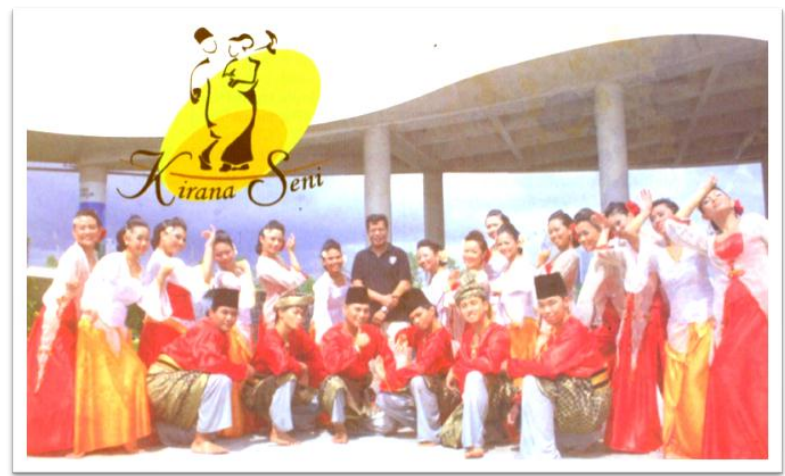

Gambar 8. Penari Kirana Seni dan koreografer Cikgu Norlie Ismail

(dokumentasi: Majlis Pusat Singapura)

\section{Ristari Zaman}

Ristari Zaman adalah pertunjukan untuk mempringati berdirinya Kirana Seni yang ke 6 pada tahun 2007. Kegiatan ini dianggap berhasil dalam perkembangan tari Melayu di Singapura yang diwadahi dari Majlis Pusat. Ini dapat dilihat dari beberapa pejabat pemerintahan Singapura yang menghadiri acara tersebut, yaitu Hawazi Daipi, Senior Parliamentary Secretary Ministry of Health and Ministry of Manpower \& Chairman, Malay Language Council, Singapore; Edmund Cheng, Chairman National Arts Council; Osman Abdul Hamid, Teater Tari Era, Lisatari (CFA NUS), PA Talens-Malay Dance; Fauziah Hanom Yusof, Presiden/Pengarah Artistik Sriwana; Som Mohammed Said PBM, Pengasas \& Pengarah Artistik Sri Warisan Som Said Performing Art Ltd, memberikan dukungan moral dalam perkembangan budaya Melayu Singapura.

Pertunjukan yang dilaksanakan pada dasarnya kelompok-kelompok tari Melayu Singapura bersatu dalam mewujudkan Ristari Zaman Kirana Seni, dengan karya terbaru masing masing kelompok tari Melayu yang ada di Singapura. Keberhasilan Majlis Pusat Pertubuhan-Pertubuhan Melayu Singapura dalam mengembangkan seni tari Melayu tidak lepas dari beberapa koreografer Indonesia yang telah memberi kontribusi yang besar dalam perkembangan tari Melayu di Singapura antara lain: Tom Ibnur, Suryamsyah, Raja Alfirafindra, yang banyak memberikan masukan lewat workshop tari Melayu, maupun pementasan yang 
JOGED

ISSN: $1858-3989$

dilaksanakan di Singapura maupun di Indonesia.

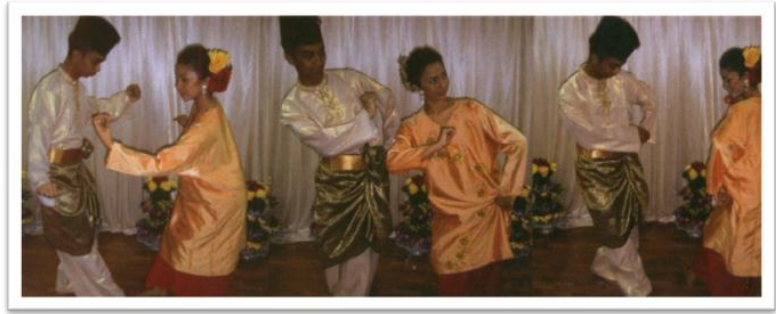

Gambar 9. Para penari Ristari Zaman Kirana Seni 4 April 2009 di Republik Politeknik TRCC Teater Singapura

(dokumentasi: Majlis Pusat Singapura)

\section{Tari Melayu yang Berkembang di Negara Serumpun (Indonesia, Malaysia, dan Singapura)}

Tari Melayu pada dasarnya mengetengahkan pada bentuk Senandung atau Langgam, bentuk Inang, bentuk Joget, bentuk Zapin dan bentuk Silat. Beberapa bentuk tari yang berkembang di Indonesia, juga dikenal di Singapura, sebagai dasar tari Melayu antara lain Tari Lenggang Patah Sembilan, Tari Mainang Pulau Kampai, Tari Tanjong Katong, Tari Anak Kala, Tari Gunung Banang, Tari Serampang 12, Tari Hitam Manis, Tari Mainang Kayangan, Tari Rentak 106 dan lainnya.

Tari-tarian ini merupakan tari dasar yang cukup dikenal di Singapura dan di Indonesia terutama di Sumatera Utara (Medan) tempat tariantarian ini bermula. Tari-tarian ini sangat dikenal di Singapura pada tahun 60-an, dengan banyak seniman-seniman Tari Melayu dan pemusikpemusik Melayu dari Medan memberikan pembelajaran musik dan tari Melayu di Singapura salah satunya Sauti yang menciptakan Tari Serampang 12.

Begitu juga keberadaan Tari Zapin yang berkembang di Johor Malaysia, berawal dari mempelajari Zapin Riau dan Zapin Siak, lalu berkembang luas di Johor, Malaysia dikarenakan Menteri Besar Johor memberi ruang kepada Yayasan Warisan Johor untuk mengembangkan Zapin di negerinya dan sekarang ini berbicara Zapin di Malaysia tidak lepas peranan dari Yayasan Warisan Johor dengan koreografer On. Rekonstruksi Zapin yang berkembang di Johor sekarang ini dapat dilihat dari Zapin Tenglu, Zapin
Raja Alfirafindra (Peran Majlis Pusat Pertubuhan-Pertubuhan Budaya Melayu Singapura dalam Festival Tari Serumpun)

Pekajang, Zapin Bunian, Zapin Johor, Zapin Putar Alam, dan banyak lagi Zapin yang dikembangkan di Johor Malaysia.

Ajang festival Zapin juga dilaksanakan oleh Yayasan Warisan Johor dengan mengundang sebagian besar peserta dari Indonesia seperti dari Provinsi Kepulauan Riau dengan Zapin Pulau Penyengat, Provinsi Riau dengan Zapin Siak, Provinsi Jambi, Bengkulu, Bangka Belitung, Lampung, Sumatera Selatan, Sumatera Utara, Aceh Darussalam, Kalimantan Barat, Kalimantan Timur, Kalimatan Selatan, Sulawesi Selatan, Ambon, Ternate, DKI, Jawa Timur, Kalimantan Tengah, Sulawesi Selatan, Singapura, dan Brunai Darussalam.Intrumen gambus untuk mengiringi tari Zapin yang berkembang di seluruh masyarakat Melayu serumpun menggunakan Gambus Selodang atau menggunakan gambus Arab atau U'd.Ciri ciri genre Gambus seperti berikut ini :

1. Tiga hingga empat Marwas (hand-drum)

2. Bentuk musikal terbagi (musical form) dalam tiga sekmen;

a. Introduksi (taksim) melalui permainan gambus a (ad.Lib)

b. Pola marwas bersahut-sahutan (beraksen) menandai atau akhir bait pantun (guatrain)

c. Syair lagu terdiri dari empat baris (guatrain)umumnya dinyanyikan dalam bentuk pantun sampiran dan isi.

d. Melodi menggunakan ornamentasi khas Melayu yang disebut Grenek (Musmal, 2010:24-25).

Keberadaan tari di Malaysia banyak dipengaruhi dari beberapa daerah Indonesia, hal ini dapat dilihat dalam maskot tari Malaysia, Negeri Perlis dengan tarian Canggung dan Inai; Negeri Kedah dengan tarian Hadrah, Ayam Didik, Gazal Parti, Cinta Sayang; Negeri Perak dengan tari Dabus dan Lenggok; Negeri Pulau Pinang dengan persembahan Chinggay dan Boria; Negeri Selangor dengan Gendang Silat dan Tarian Bugis;Wilayah Persekutuan dengan persembahan dengan berbagai bentuk repertoar berbagai etnik;Negeri Sembilan dengan tari Rantak Kudo, Piring, dan Tumbuk Kalang; Negeri Malaka dengan Dondang Sayang, Ronggeng dan Joget Lambak; Negeri Johor dengan Zapin dan Kuda Kepang; Negeri Kelantan dengan Persembahan Makyong, Dikir Barat dan Menora; Negeri Terengganu persembahan Rodat dan Joget Gamelan; Negeri Pahang dengan Joget Pahang, 
dan tarian Labi Labi;Negeri Sabah dengan tarian Mangilok dan Mangunatip;Negeri Serawak dengan tari Ngajat, Ajat atau Kanjet (Imran, 2011: 81).

Provinsi Kepulauan Riau dan Provinsi Riau pada setiap acara festival Melayu baik tingkat nasional maupun internasional selalu mengundang negara Melayu serumpun Singapura, Malaysia, Brunai dan Indonesia dalam hal ini Kepulauan Riau dan Riau, Festival yang pernah diselenggarakan seperti: Festival Melayu sedunia di Pekanbaru Riau, Festival Melayu di Tanjung Pinang, Festival Zapin di Tanjung Pinang, Kenduri Melayu di Batam, Festival Dangkong di Karimun, Revitalisasi Budaya Melayu di Tanjung Pinang, Rampai Budaya Melayu di Pelalawan, Festival Siak Bermadah di Siak Sri Indrapura, Festival Sri Gemilag di Tembilahan.

Festival-festival tari melayu yang diselenggarakan oleh beberapa daerah di Indonesia beberapa kelompok tari dari Singapura selalu mengikuti antara lain Kirana Seni Majlis Pusat pertubuhan-pertubuhan Budaya Melayu Singapura koreografer Norlie Ismail, Sri Warisan dengan koreografer Som Said, Sriwana dengan koreografer Fauziah Hawai, Era Dance Theatre koreografer Osman Hamid, Aspirasi koreografer Azmi Johari, Dharma koreografer Faturahman Said.

Koreografi kelompok-kelompok tari Melayu di Singapura kebanyakan karyanya mengetengahkan bentuk joget yang telah dikembangkan. Namun dapat dirasakan kebanyakan koreografer pemula di Singapura yang berpijak pada konsep Melayu tidak memahami arti joget yang susungguhnya. Lain halnya dengan joget yang berkembang di Kepulauan Riau, terorganisir dalam suatu kumpulan yang disebut Pasok. Setiap Pasok Joget terdiri dari Pemimpin Joget yang disebut Wak Joget, dan istri Wak Joget disebut juga Mak Joget; Panjak Joget terdiri dari 1 orang pemukul Tambur, 1 orang Penggesek Biola, 1 orang pemukul kecapak; dan penari joget terdiri dari 4 sampai 10 penari sekaligus sebagai penyanyi dan berpantun. Dalam pertunjukan Joget biasanya dilakukan beberapa lagu yang memberikan tahapan proses pertunjukan Joget antara lain :

\section{Lagu Betabek}

Disebut juga dengan pembuka tanah yang memberi pesan kepada penonton sebagai pemula dalam pertunjukan Joget. Syair yang dilantunkan oleh penyanyi Joget mengandung makna selamat datang kepada penonton dan meminta maaf jika dalam pertunjukan Joget nantinya tidak sesuai dengan apa yang diharapkan dari pihak yang mengundang. Menurut sebagaian besar masyarakat di Kepulauan Riau, ketika lagu Betabek dimainkan, anak anak muda dan laki-laki yang baru menikah dilarang memandang wajah penari, dikarenakan nantinya akan tergila-gila dengan penari Joget tersebut lewat mantra mantra yang disampaikan oleh pawang atau dukun kelompok Joget tersebut. Mantra mantra yang disampaikan akan memberikan aura kecantikan dan kemerduan penari dan penyanyi selama pertunjukan berlangsung.

\section{Lagu Dondang Sayang,}

Seluruh penari wanita menarikan dalam satu repertoar tari sebagai tari selamat datang, dengan rentak langgam atau senandung (lambat)

\section{Lagu Serampang Laut,}

Seluruh penari wanita sudah bisa menari dengan pasangan penari putra, dengan syarat penari putera terlebih dulu membeli karcis sesuai kesepakatan dari pimpinan joget. Rentak dalam lagu Serampang Laut dengan bentuk Joget (cepat).

\section{Lagu Patam Patam,}

Seluruh penari menarikan dengan rentak joget yang sangat cepat dengan langkah dua. Lagu patam patam sangat berkembang di Melayu Deli, Medan Sumatera Utara. Setelah itu baru dilakukan dengan selingan lagu lagu yang bertempo sedang seperti rentak Inang, rentak Langgam, rentak Joget, dan rentak zapin semuanya sesuai permintaan dari para pengunjung dan pengibing.

Joget yang berkembang di Kapulauan Riau adalah: Joget Duara, Joget Sekanak, Joget Tanjung Biru, Joget Teluk Tangku, Joget Bakong, Joget Posek, Joget Sugi atau Joget Moro, Joget Tembeling, Joget Mantang Arang, Joget Sawang, dan Joget Kasu. Di Kabupaten Bengkalis disebut dengan Joget Bontek, dan di Rupat disebut Joget Hutan. Di Kabupaten Indragirihilir disebut dengan Joget Belaras, Joget Bogong, dan Joget Bontaian.

Keberadaaan letak geografis Singapura dengan Provinsi Kepulauan Riau, Malaysia dan Provinsi Riau, sangat mempengaruhi keberadaaan dan perkembangan joget, ini dapat dilihat dari tokoh Joget yang terkenal di 
JOGED

ISSN: 1858-3989

Riau pada masa lalu bernama Kencong berasal dari Moro Kepulauan Riau, adalah pemain biola yang terkenal sampai ke Singapura dan Malaysia. Kencong adalah guru dari Dolmat ayah dari Hamzah Dolmat, seorang pemain biola terkenal di Singapura dan Malaysia. Dolmat berasal dari Mantang Arang, kecamatan Bintan Timur Kepulauan Riau (Kadir, 1994: 2-16).

Dalam pengamatan penulis yang telah beberapa kali terlibat dalam Festival Tari Serumpun, festival tari Melayu di Nusantara, kehadiran delegasi Singapura umumnya karya tarinya masih bersifat tari-tari Melayu yang berkembang pada masa lalu, seperti Langgam, Inang, Joget, Zapin dan Silat. Terasa sekali konsep garapan tari Melayu Singapura berbeda dengan karya karya tari Melayu masa kini. Hal serupa juga dirasakan beberapa tokoh tari di Singapura. Kelebihan karya tari Melayu Singapura ada pada busana yang dikenakan yang dibuat begitu semarak dan mewah, namun kadangkala tidak sesuai dengan tema yang diangkat. Hal ini menjadi inspirasi sebagian seniman tari di Kepulauan Riau dan Riau, yang mengikuti jejak seperti Singapura yang mengandalkan busana Melayu lengkap tetapi tidak sesuai dengan tema garapan. Andalan karya tari Melayu Singapura juga pada permainan komposisi pola lantai penari yang sangat memperhitungkan ke luar masuk penari, tetapi tema dan konsep sebagian besar hanya sebatas repertoar dalam rentak Langgam, Inang, Joget, Zapin, dan Silat. Hal ini disadari sebagian seniman tari di Singapura sangat sulit untuk mengatasi hal serupa dikarenakan Singapura lebih bersifat modern dengan segala aspek sehingga bentuk bentuk repertoar masih dalam lingkup tari Melayu Cantik, sedangkan bentuk, teknik, dan isi, hanya sebatas yang mereka kenal sekarang ini, dan makna dari gerak sebagian besar mereka tidak mengerti hakikat dari tari Melayu itu sendiri.

\section{Kesimpulan}

Majlis Pusat Pertubuhan-Pertubuhan Budaya Melayu Singapura adalah suatu badan yang telah menyatukan keberadaannya dalam menjunjung harkat dan martabat masyarakat melayu Singapura pada khususnya. Ini dapat dilihat bagaimana Majlis Pusat dalam melakukan beberapa kegiatan yang
Raja Alfirafindra (Peran Majlis Pusat Pertubuhan-Pertubuhan Budaya Melayu Singapura dalam Festival Tari Serumpun)

berskala besar seperti: Festival Melayu Serumpun, Rewang Nak Tari, dan Ristari Zaman.Festival Melayu Serumpun salah satu kegiatan yang menghadirkan beberapa kelompok tari dari negara Malaysia, Indonesia, Singapura, Thailand, dan Brunai Darussalam.

Dalam kegiatan ini pihak Majlis Pusat memberikan pembelajaran kepada kelompokkelompok tari Melayu Singapura untuk melihat secara langsung koreografi tari Melayu yang berkembang di masing-masing negara, sehingga hal ini menjadi motivasi untuk kelompok tari Melayu Singapura. Majlis Pusat dalam penyelenggaraan Festival Tari Serumpun dalam manajemen pertunjukan dan fasilatas pertunjukan sangat modern, berbeda dengan Indonesia yang jauh sekali dalam fasiltas pertunjukannya. Pembelajaran yang dapat dihasilkan dalam Festival Melayu Serumpun yang dilaksanakan oleh Majlis Pusat Pertubuhan-Pertubuhan Budaya Melayu Singapura, merupakan langkah awal untuk memberikan wacana baru dalam perkembangan Tari Melayu dengan kekinian dengan tidak meninggalkan esensi dari tari melayu pada umumnya

\section{DAFTAR RUJUKAN}

Imran, Mhd. Nefi, 2011, Tari Melayu Malaysia: Satu Kajian Berdasarkan Festival Tari Kebangsaan, Kuala Lumpur:Akademi Seni Budaya dan Warisan Kebangsaan Kementrian Penerangan, Konunikasi dan Kebudayaan.

Kadir, Mohd. Daut, 1994, Lagu-lagu Joget Tradisional Daerah Riau, Pekanbaru: Dewan Kesenian Daerah Riau.

Musmal, 2010, Gambus Citra Budaya Melayu,Yogyakarta: Media Kreativa.

\section{Sumber Lisan:}

Cekgu Hisam, Pengajar Bahasa Melayu di Singapura dan Pernah Aktif Sebagai Staf Majlis Pusat.

Cikgu Norlie Ismail 